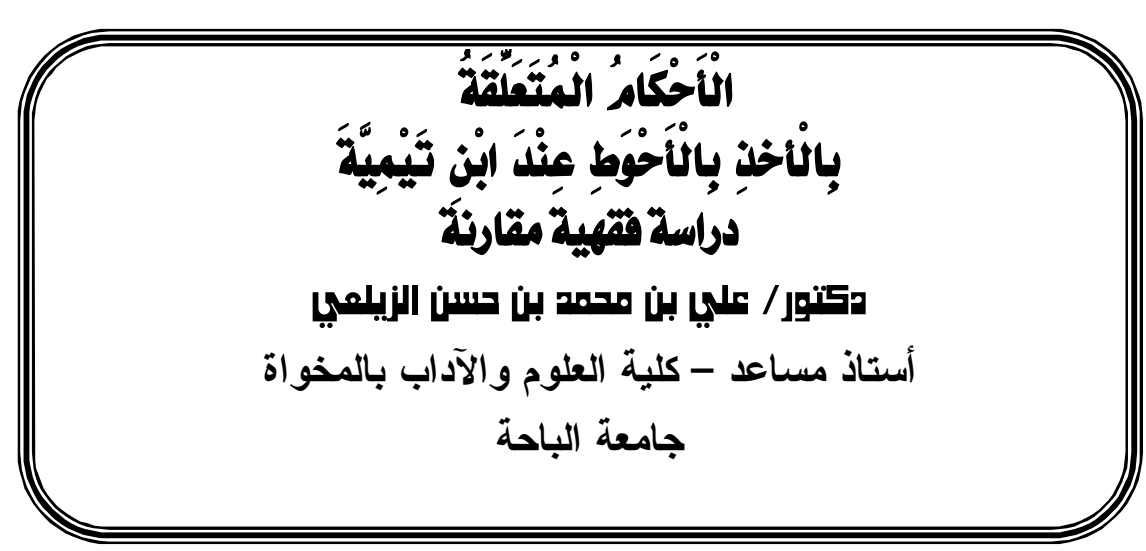

$$
\text { بسم الله الرحمن الرحيم }
$$

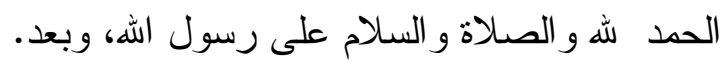

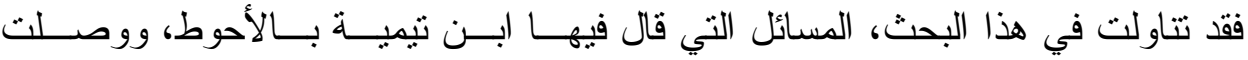

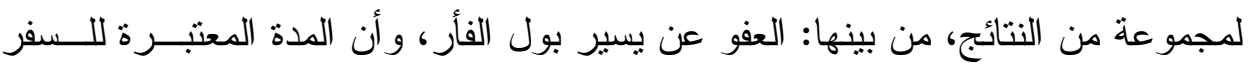

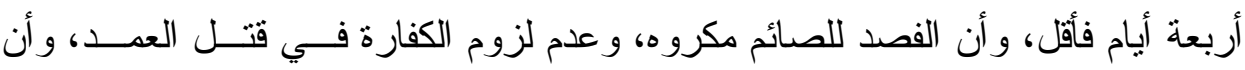
شيخ الإسلام ابن تيمية إمام مجتهد مطلق منتسب. و آخر دعو انا أن الحمد لله رب العبن العالمين. كلمات مفتاحية: فقه ابن تيمية - الاحتياط في الفتوى - القول بالأحوط.

\title{
Abstract
}

Praise be to God, prayer and peace be upon the Messenger of Allah and after.

In this research, I dealt with the issues in which Ibn Taymiyyah said with caution, and reached a set of results, including: pardoning the walking of the mouse's urine, and that the period considered for travel is four days or less, and that the ransom of the fasting person is reprehensible, and the penance is not required in killing the mayor, and that the sheikh Islam Ibn Taymiyyah is an imam who is diligent, divorced, and associated.

And Praise be to Allah, the Lord of the Worlds.

Key words: Ibn Taymiyyah jurisprudence - precaution in the fatawa - uttering precaution 


$$
\text { بسم الله الرحمن الرحيم }
$$

\section{خطبة المقدمة}

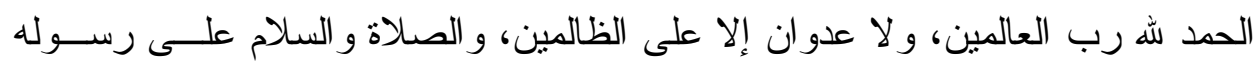
الأمين، و آله وصحبه أجمعين، أما بعد: العدان

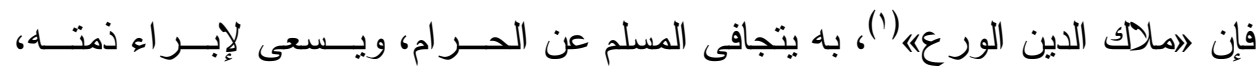
وسلامة عرضه.

ومن صور الورع: الاحتباط في الأحكام الثرعية، قال الثشاطبي رحمه الله: "فالاحتبــاط للاين ثابت من الثريعة، مخصص لعموم أصل الإباحة إذا ثبت" (؟).

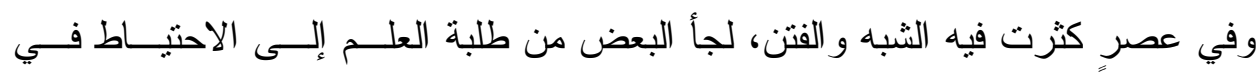

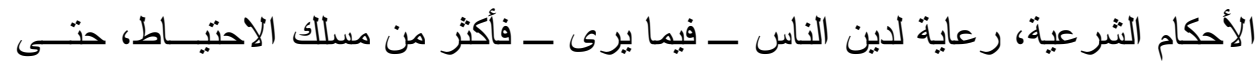

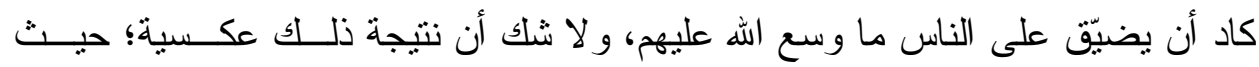

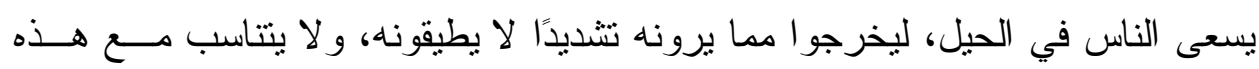

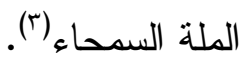

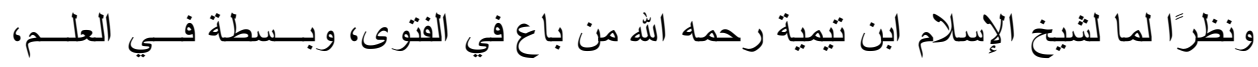

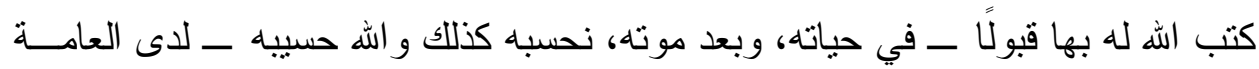

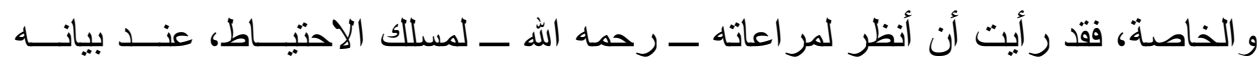
للأحكام الثرعية؛ ليكون أنموذجًا يحتذي به طالب العلم المحقق، في عصرنا هذا، فكان اعنه رانه

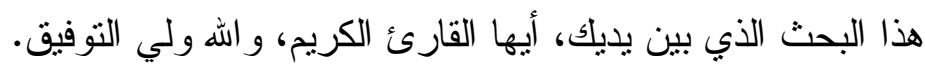

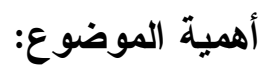

انتشر في الآونة الأخيرة الفتيا بالأحوط، و القول بالأحوط، مما أدى إلــى التـشديد

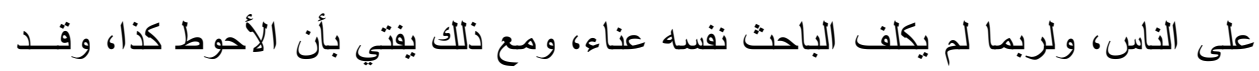

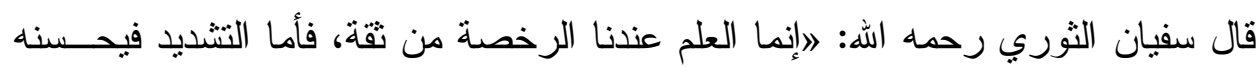

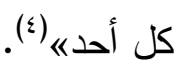

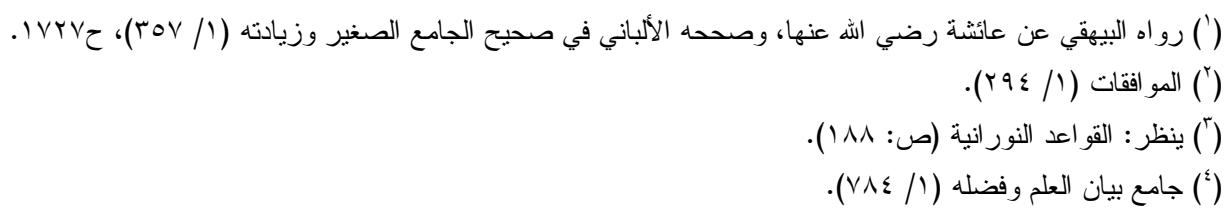


الار اسات السابقة:

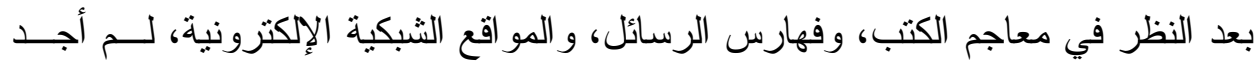

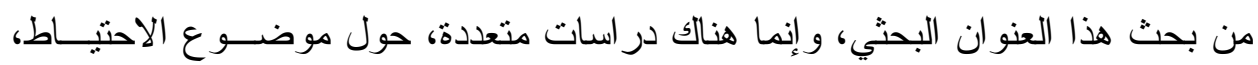

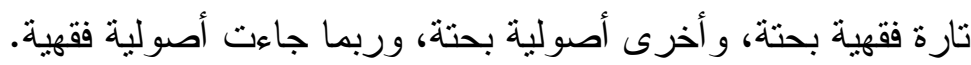

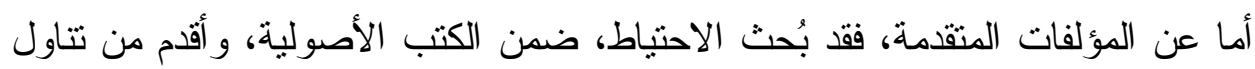

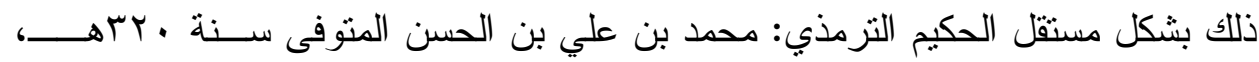

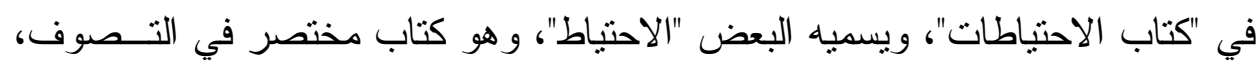

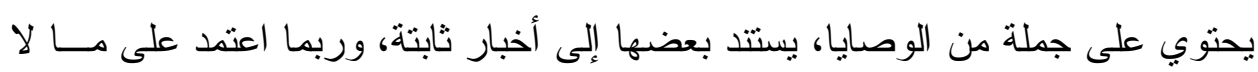

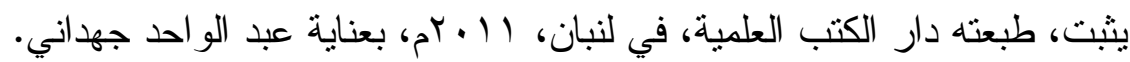

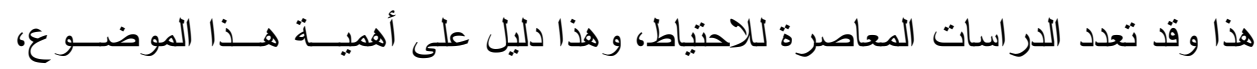

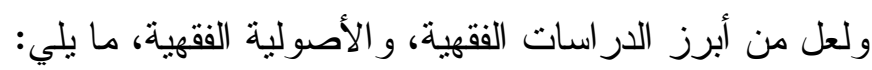

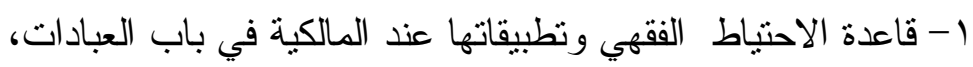

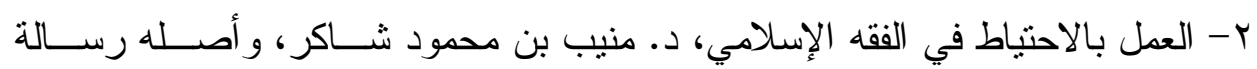

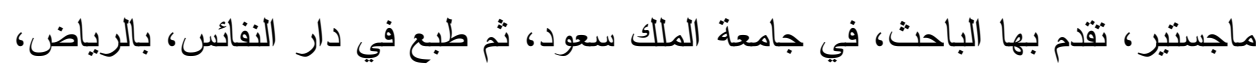

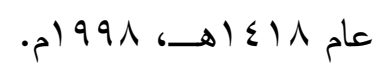

ب- قاعدة الاحتياط الفقهية، وأثزها في الطهارة الثرعية، بحث تكميلي مقدم لنيل درجة

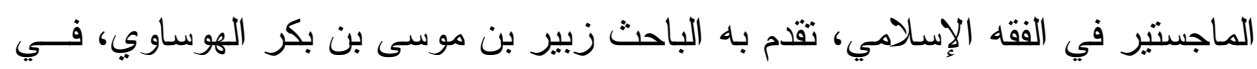

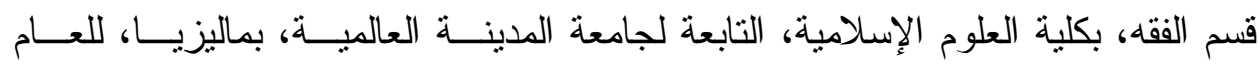

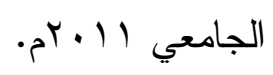

ع- نظرية الاحتياط الفقهي، إعداد الباحث: محمد عمر سماعي؛ اســتكمالا لمتطلبــات

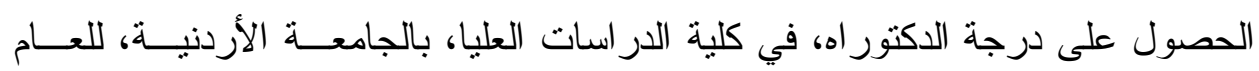

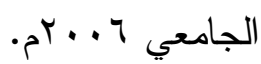
0- قو اعد الأخذ بالأحوط: ضو ابطها و تطبيقاتها الفقهية في مجال العبـادات، رســالة ماجستير، تقدم بها الباحث إير اهيم محمد الرفاعي، للجامعة الأردنية.

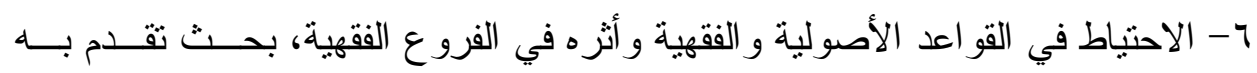

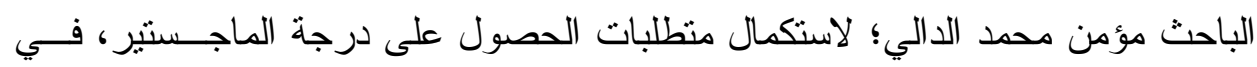
أصول الققه من كلية الثريعة و القانون بالجامعة الإسلامية بغزة. 
- قاعدة الاحتياط في الاختلاط بين الجنسين، بحث تقدمت به الباحثة رزقي نور أوكتا

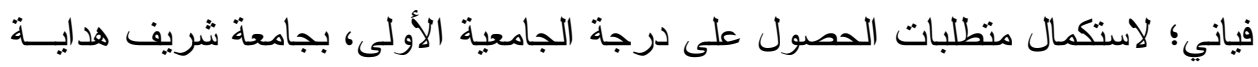

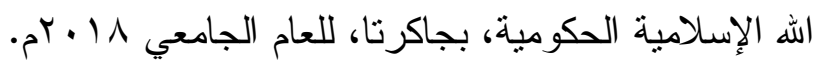

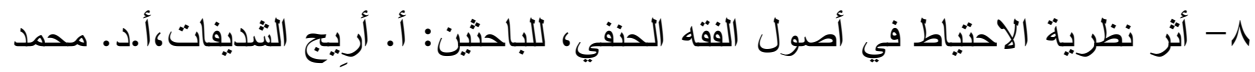

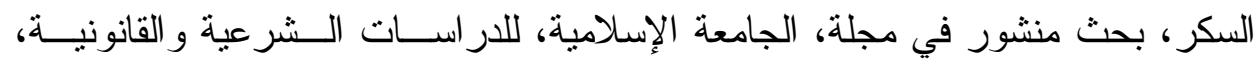

9- الاحتياط الثرعي.. حقيقته وضو ابطه، بقلم د. قطب الريسوني، بحث منشور علـى الثبكة العنكبونية.

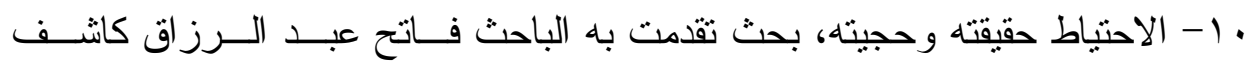
الغطاء، استكمالا لمنطلبات الحصول على درجة الماجستير ، في كلية العلوم الإســلامية،

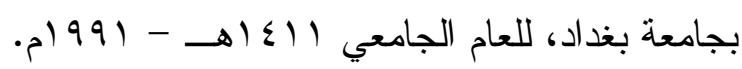

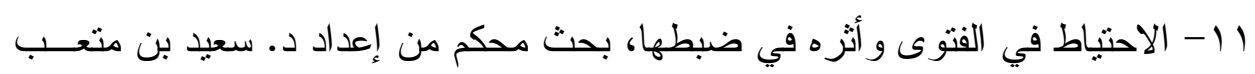

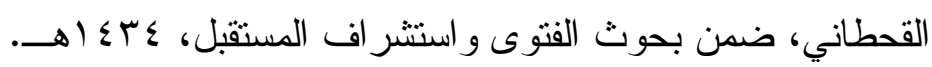

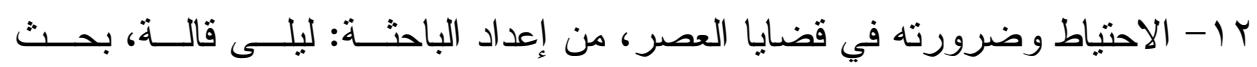

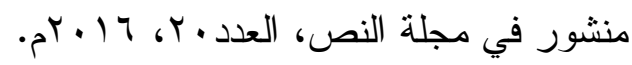
منهج البحث: منتور فئ اعتمدت المنهج الوصفي التحليلي، وهو الأنسب لمنل ما نحن فيه من البحوث الإنسانية، وسرت وفق الخطو ات التالية: 1- جعلت الآيات الكريمة بين قوسين مزهرين، وعزوتها لسور ها، مع رقم الآية. r - خرجت الأحاديث الثريفة الواردة في صلب البحث، من مظانها، فإن كان الحديث هزيث

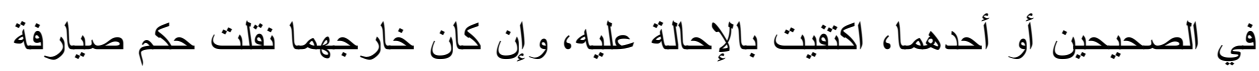
هذا الثأن. ب- أذكر أقو ال العلماء في المسألة، وربما نقلت بعض نصوصهم، مع سياق أدلــة كـلــ فريق.

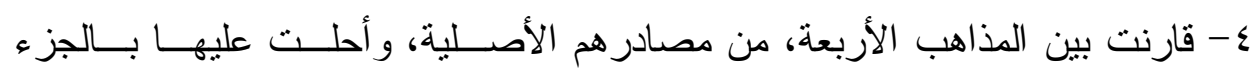

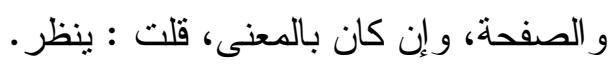
ه- إذا قلت في هذا البحث: شيخ الإسلام، فمر ادي الإمام تقي الدين أحمد ابن تيمية. 
7- جمعت آر اء شيخ الإسلام في الأخذ بالأحوط، من عامة كتبه المطبوعة و المتاحة.

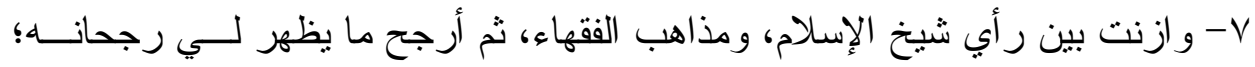
مر اعيًا قوة الدليل، ومقاصد الثريعة، وما توفيقي إلا باله، عليه توكلت و إليه أنيب. وما توفيقي إلا بالله عليه توكلت و إليه أنيب. خطة البحث: تشتثل الخطة على تمهيد، وتحته مسألتان، ثم مبحثنان، تحت كل منهما ثلاتـــة مطالــب، على النحو التالي: التمهيد: وفيه مسألتان: المسألة الأولى: تعريف الاحتياط لغة، و اصطلاحاً. المسألة الثانية: قو اعد ابن تيمية في الاحتياط. المبحث الأول: الأحكام المتعلقة بالأخذ بالأحوط في العبادات: المطلب الأول: الأخذ بالأحوط في غسل بول الفأر .

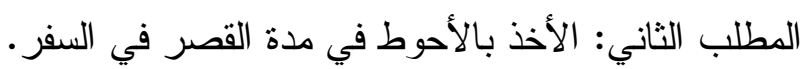
المطلب الثالث: الأخذ بالأحوط في الصوم، وفيه فرعان: الفرع الأول: الأخذ بالأحوط عند العجز عن صوم الوالاجب.

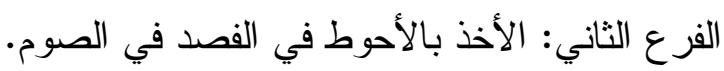

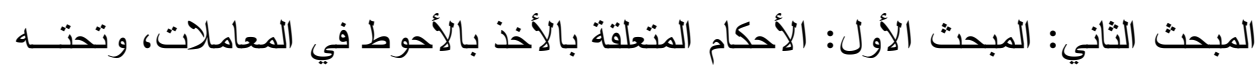
ثلاثة مطالب: المطلب الأول: الأخذ بالأحوط في توكيل الذمي في قبول نكاح المسلمة.

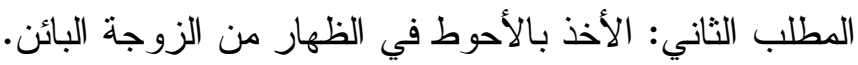

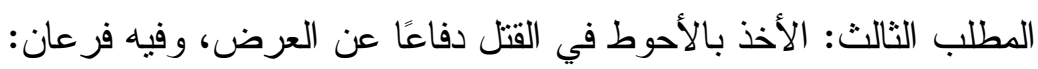

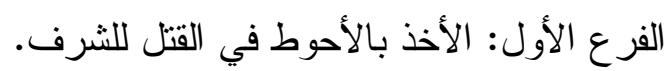
الفرع الثاني: الأخذ بالأحوط في كفارة القتل العمد. الخاتمة: وفيها أهم النتائج و التوصيات. 
المسألة الأولى: تعريف الاحتياط لغة، واصطلاحاً. أو لاً: تعريف الاحتياط لغةً: الألة

الاحتياط لغة افتعال من حاط يحوط، حوطاً (').

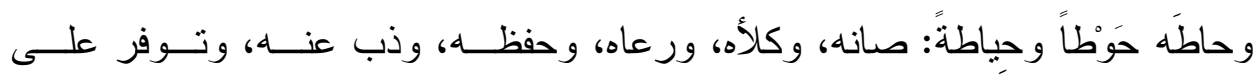

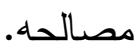
و الحَوْطةُُو الحَبْطة: الاحْتِياطُ، واحتاط الرجل لنفسه: أخذ في الحزم، وبالنقة.

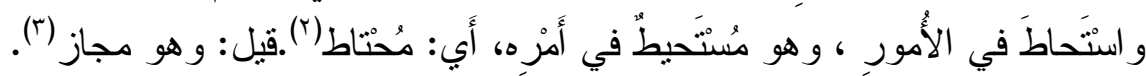

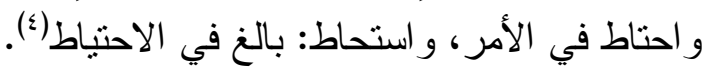

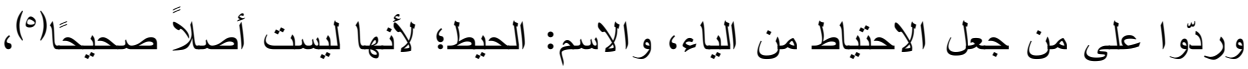

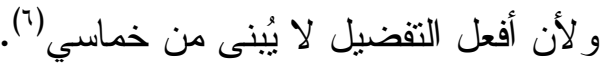

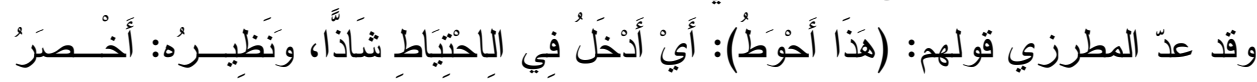

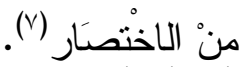

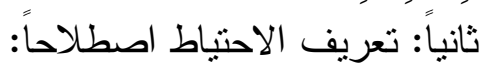
وردت عدة تعاريف للاحتياط، تدور حول معنيين:

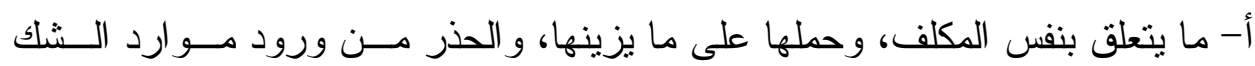

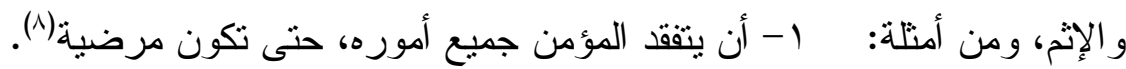

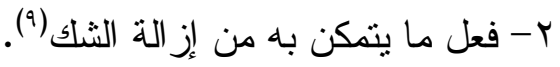

(') ينظر : المصباح المنير في غريب الثرح الكبير (1/ / 107)، و (حوط): أصل صحيح، وكلمة واحدة، وهو الثيء يطيـف

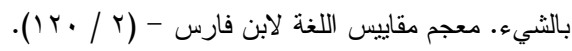

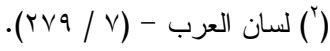

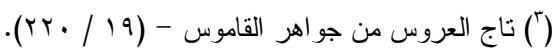

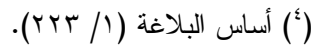

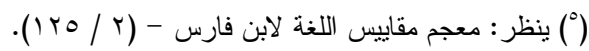

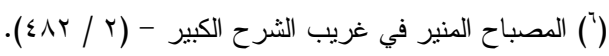

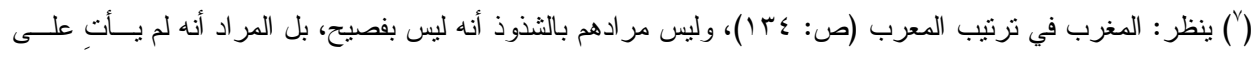

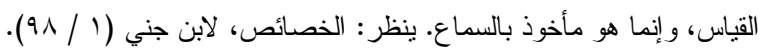

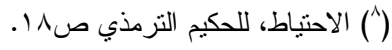

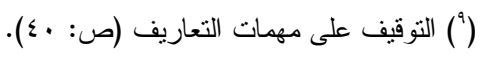


" ا- اجتتاب ما يتقي المرء أن يكون غير جائز ، وإن لم يصح تحريمه عنده(').

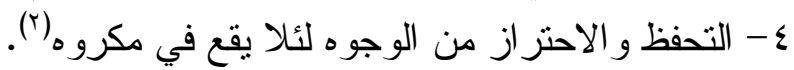

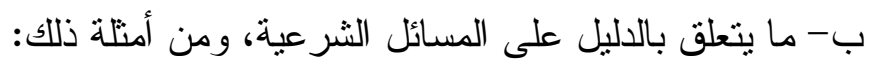
1- تعريف الكمال بن الهمام: العمل بأقوى الداليلين(").

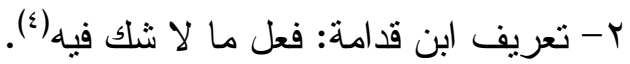
ب- تعريف الفيومي: فعل ما هو أجمع لأصول الأحكام، وأبعد عن شو ائب التأويل(ه).

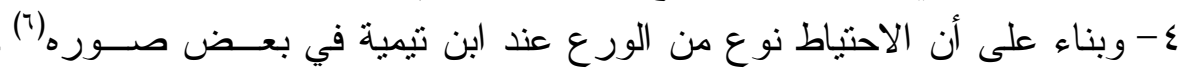

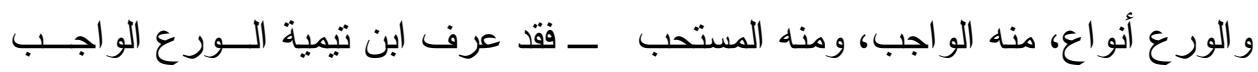

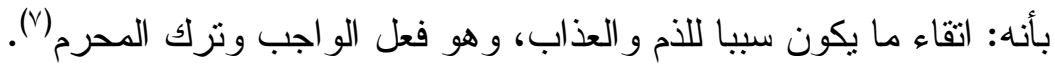

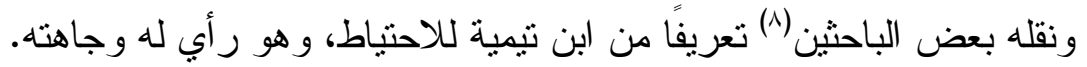

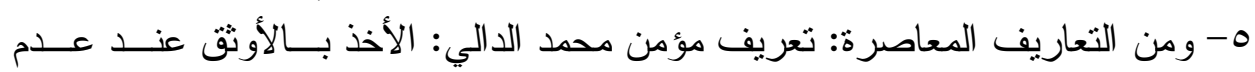

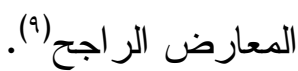
צ- و عرفه د. منيب بن محمود شاكر : الاحتز از من الوقوع في منهي، أو نرك مــأمور عند الانشتباه(·').

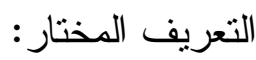
بناء على ما سبق يمكن أن يكون التعريف المختار للاحتياط، هو :

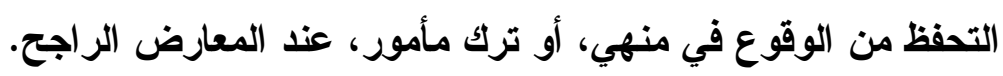

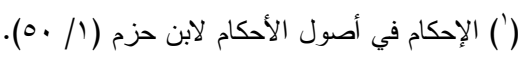

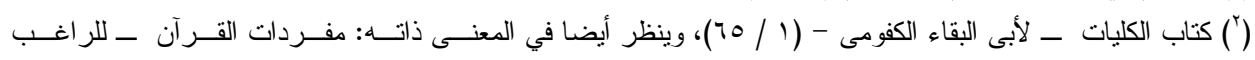

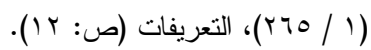

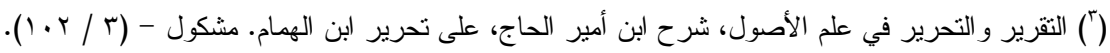

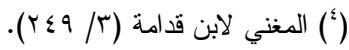

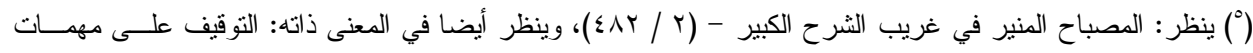

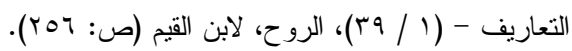

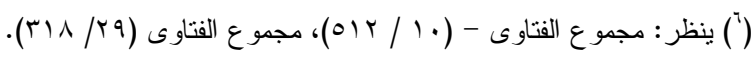

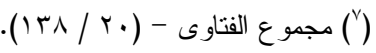

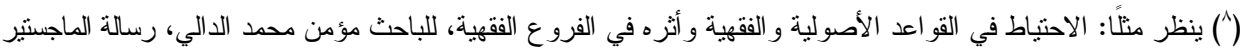

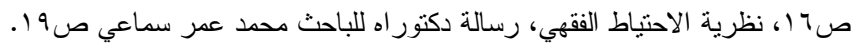

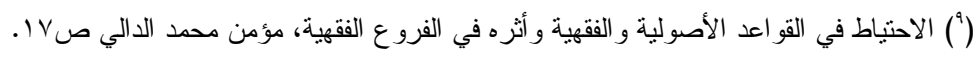

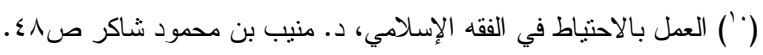


المسألة الثانية: قواعد في الاحتياط من كلام شيخ الإسلام ابن تيمية:

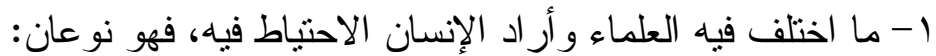
أ- ما اتفقو ا على جو از الأمرين فيه، ولكن تتازعو ا في الأفضل منهما. ب- ما نتازعو ا في جواز أحدهما. وكثير مما تتازعو ا فيه جاءت السنة فيه بالأمرين، منل فسخ الحج إلى عمرة، و الــصوم

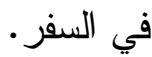
Y- أكثر الأئمة لا يميزون بين المفروض والمسنون، في الصلاة، ولو كان العلم بهـــا

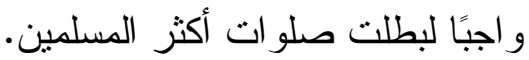
و لا يمكن الاحتياط في كثير من ذلك؛ للاختلاف فيه، وخفاء أدلته، و أكثــر مـــا يمكـن لللتدين في ذلك أن يحتاط من الخلاف.

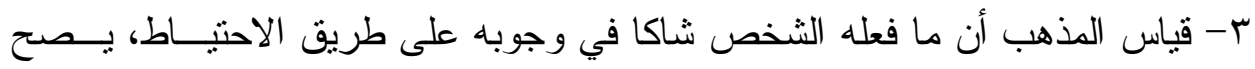

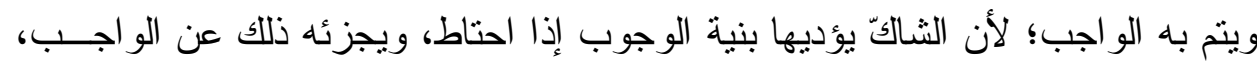
حتى لو تبين له فيما بعدُ الوجوب أجز أه.

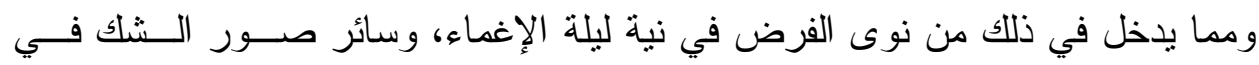

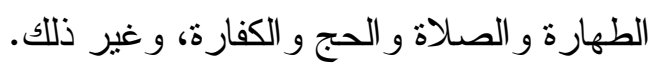

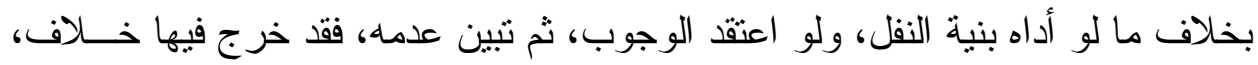

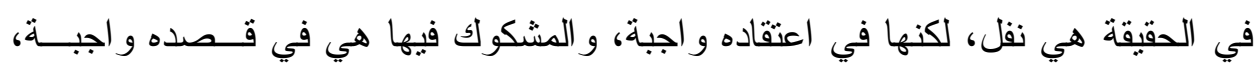
و الاعتقاد متردد.

ع - من الورع الاحتياط، بفعل ما يُشتك في وجوبه، وليس في فعله مفسدة أعظــــ مـن تزكه.

وتمام الورع أن بعلم الإنسان خير الخيرين وشر الشرين، ويعلم أن الثريعة مبناها على

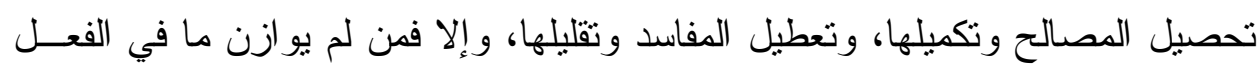

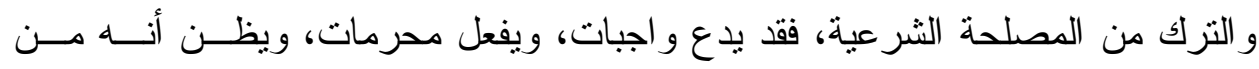
الورع.

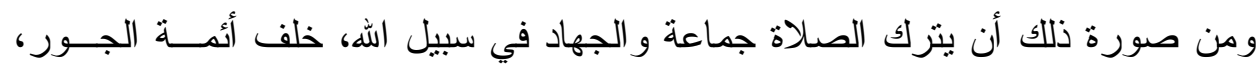

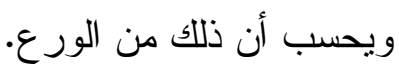


ه- إذا جعل الإنسان في تقديره، وجود عقوبة على فعل ما، فإن ذلك أدعى لنجاته؛ ولذا

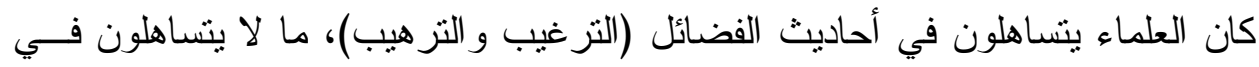

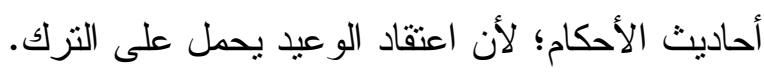

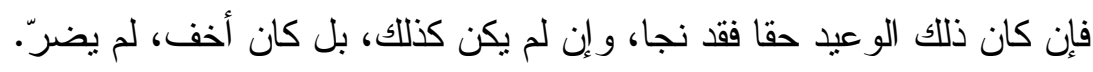

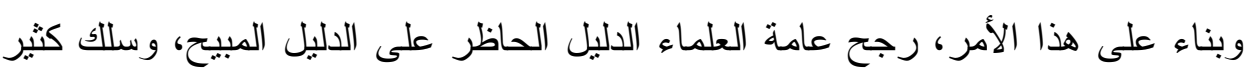
من الفقهاء دليل الاحتياط في كثير من الأحكام. צ- الاحتياط في الفعل كالمجمع على حسنه، بين العقلاء في الجملة.

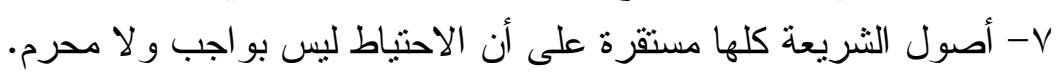

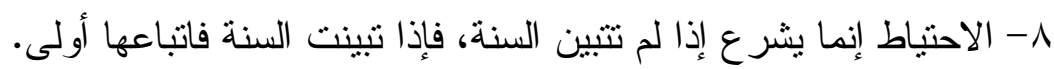
9- الاحتياط حسن ما لم يخالف السنة المعلومة، فإذا أفضى إلى ذلك كان خطاً.

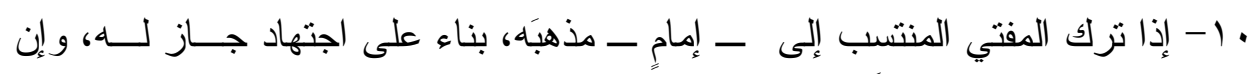

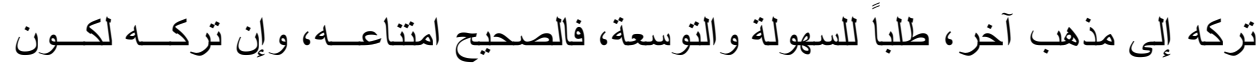

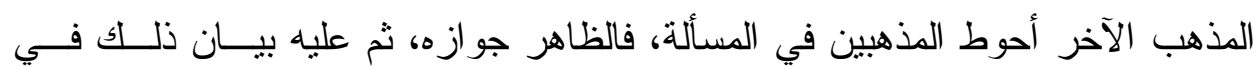
فتو اه. 
المبحث الأول: الأحكام المتعلقة بالأخذ بالأحوط في العبادات:

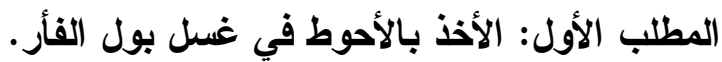

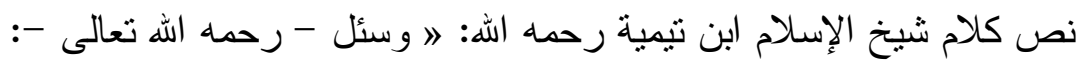

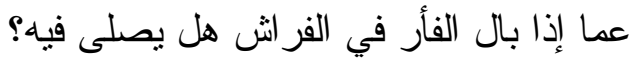
فأجاب: غسله أحوط ويعفى عن يسيره في أحد قولي العلمــاء وهــو إحــدى الــرو ايتين عـن

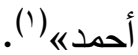
أقو ال الفقهاء في المسألة: اختلف العلماء في حكم بول الفأر إذا أصاب الثوب، ونحوه، على خمسة أقو ال:

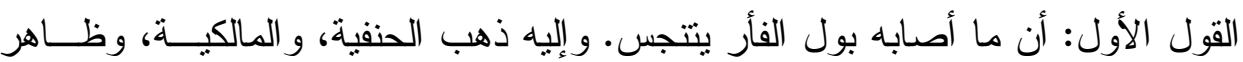

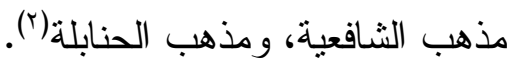
الدليل:

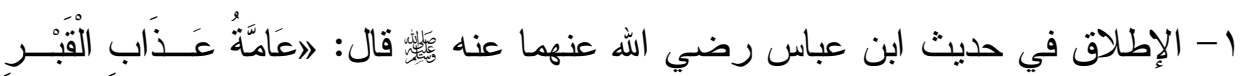

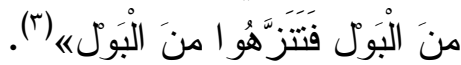
Y- ومثلكه قوله عليه الصلاة والسلام لعمار بن باسر : الإنما يغسل الثوب مــن المنـي

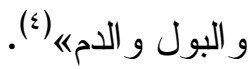
ץ- إن بول الفأر فضلة من محرم الأكل، وقد ثنتت نجاسته بنص لم يعارضــه غيــره

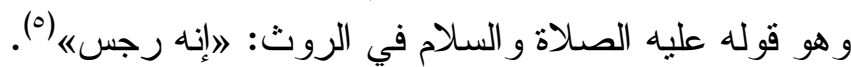

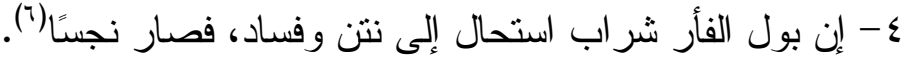
ه- إنه منفصل عن حيوان يمكن التحرز عنه فصار نجسا كبول الآدمي (Y).

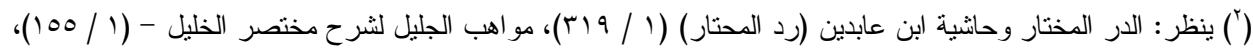

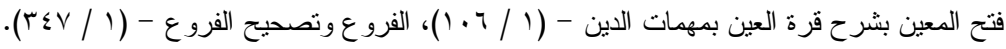

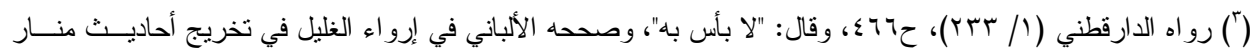

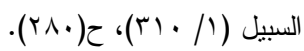

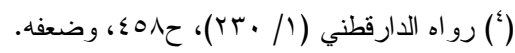

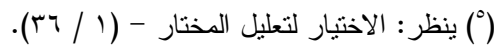

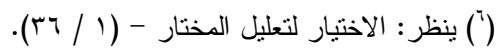

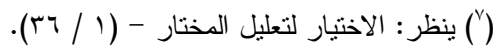


צ- لخفة الضرورة، في بول الفأر ؛ فلا يعفى عنه(').

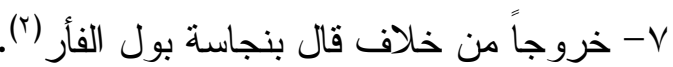

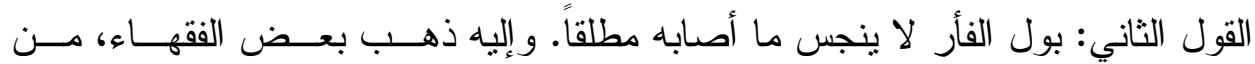
الحنفية و المالكية|(r).

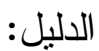

1- إن الفأر مباح الأكل، كما ورد عن عائشة سئلت عن أكل الفأرة فتلت قوله تعـالى:

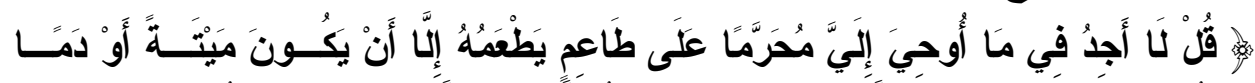

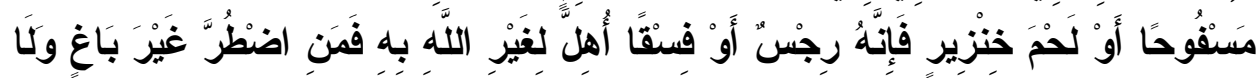

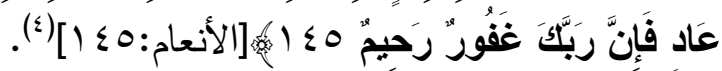

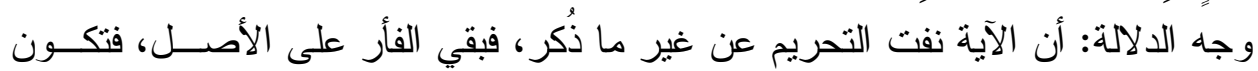
فضلته طاهرة: (0). ץ- إن الأصل في بول الفأر الطهارة، ولم يرد ما يخرجه عن هذا الأصل(؟).

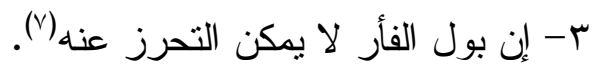

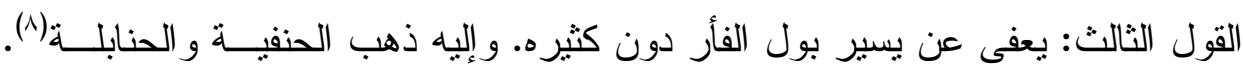

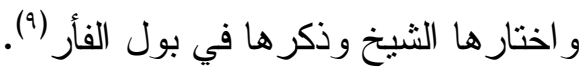

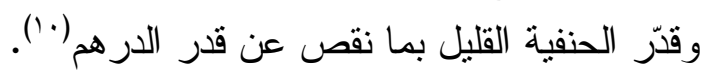

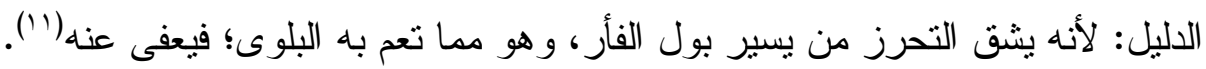

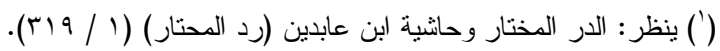

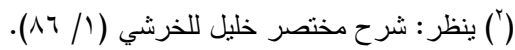

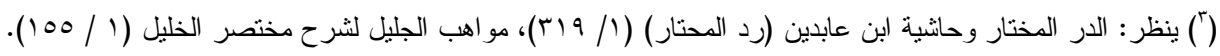

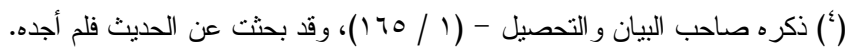

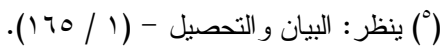

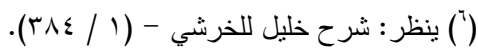

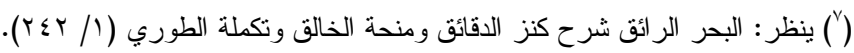

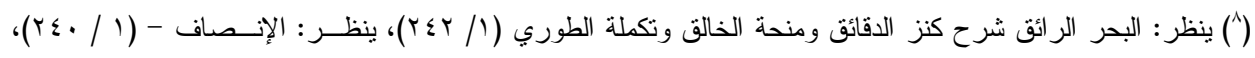

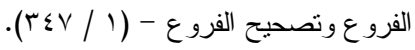

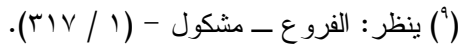

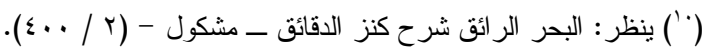

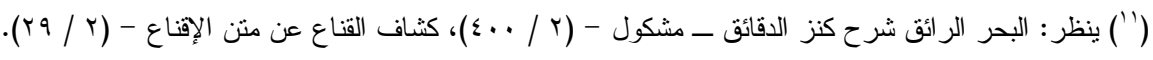


القول الر ابع: كر اهة استعمال ما أصابه بول الفأر . وهو قول عند المالكية('). الاليل:

1- إن شأن الفأر استعمال النجاسة، فيكره أكله، ويحكم بنجاسة فضلته احتياطاً(؟).

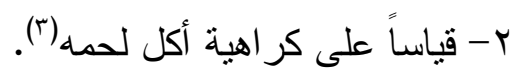
القول الخامس: يُنجِّ الماء دون الطعام و الثياب. وهو قول عند الحنفية('). الدليل:

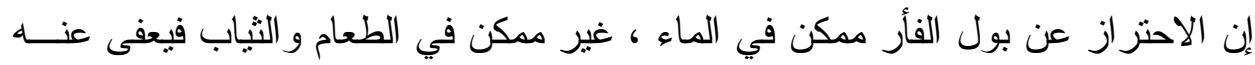
فيهما (๕) الموازنة بين رأي شيخ الإسلام و أقو ال الفقهاء:

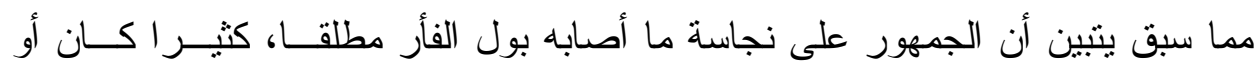
يسير ا. وقد مال شيخ الإسلام إلى العفو عن يسير بول الفأر، وهو قول عند الحنفية والحنابلـــة، و إن كان الأحوط لديه الغسل. التزجيح: الذي يترجح لدى الباحث هو القول بالعفو عن يسير بول الفأر؛ لأنه مما تعـــ

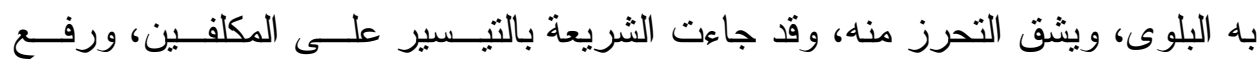

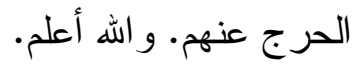

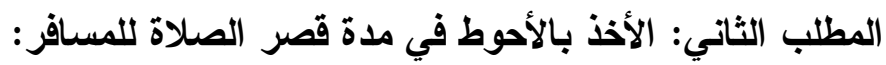

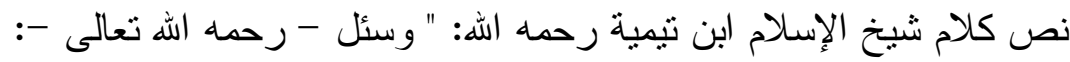
عن رجل مسافر إلى بلد ومقصوده أن يقيم مدة شهر أو أكثر فهل يتم الصناة أم لاج فأجاب:

إذا نوى أن يقيم بالبلد أربعة أيام فما دونها قصر الصلاة كما فعل النبي صلى الله عليـهـ ألها.

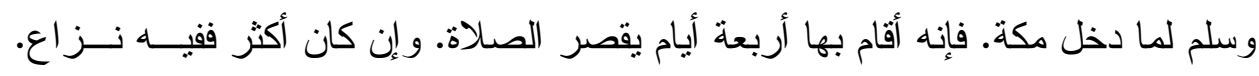
و الأحوط أن يتم الصـلاة. و أما إن قال غدا أسافر أو بعد غد أسافر ولم ينو المقــام فإنـــهـ

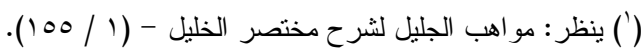

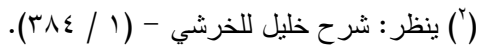

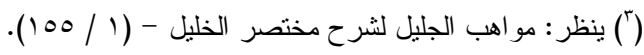

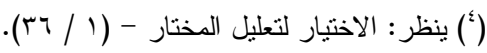


يقصر أبدا فإن \}النبي صلى الله عليه وسلم أقام بمكة بضعة عشر يوما يقصر الــصلاة

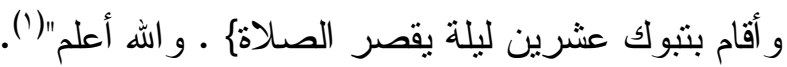

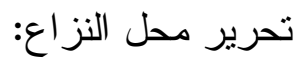
1- اتفق الفقهاء على أن الشخص إذا أقام لحاجة ينتظر قضاءها، يقول: اليوم أخـرج، غدا أخرج، فإنه يقصر أبدًا (ب). Y- كما اتفقو ا على أنه إذا استوطن بلدًا، بأن نوى فيه الإقامة مطلقا؛ فقد انقطع ســفره،

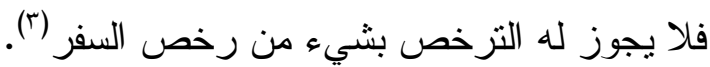
خلاف العلماء:

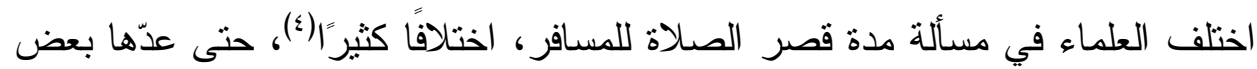

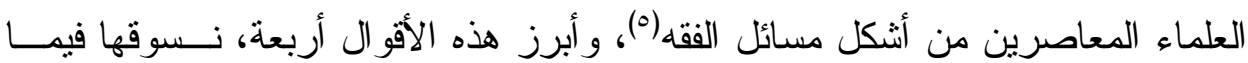
يلي: القول الأول: مدة القصر ثناثثة أيام، فإن نوى المسافر أكثر منها لزمه الإتمــام. و إليــــ

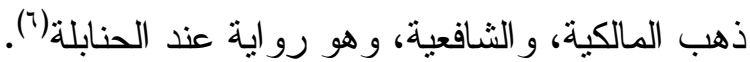

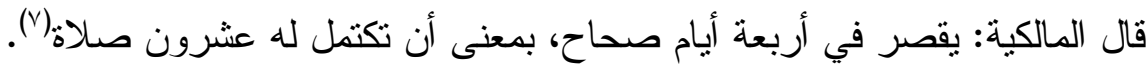

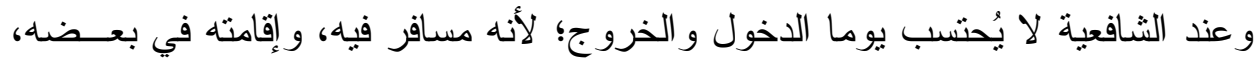

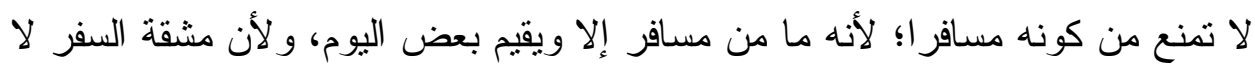
تزول إلا بإقامة يوم تامّم(A). الأدلة:

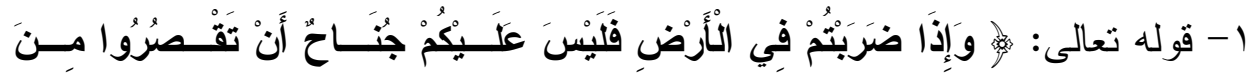

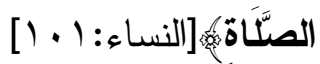

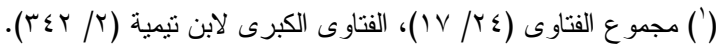

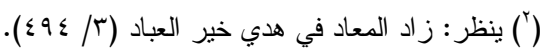

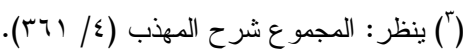

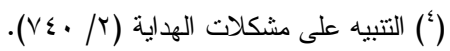

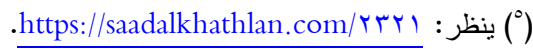

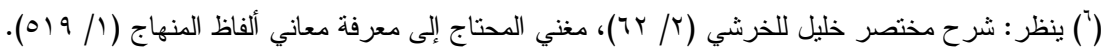

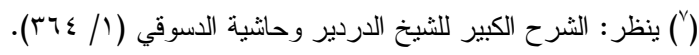

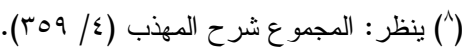




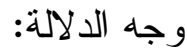

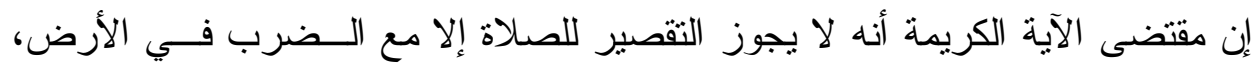

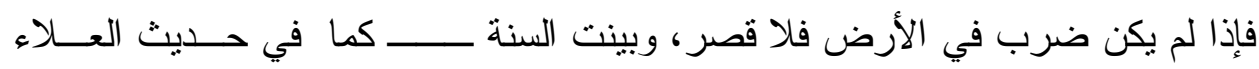

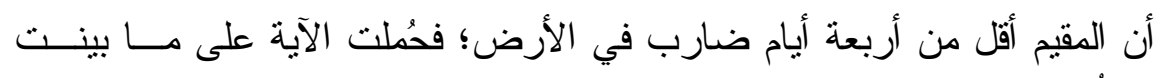

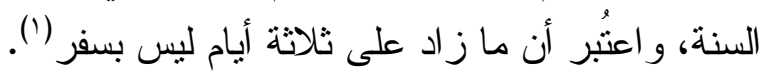

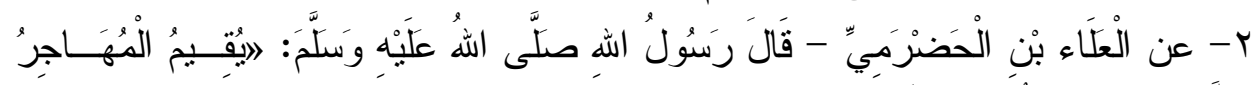

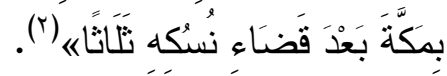
وجه الدلالة: إن المقام بمكة حر ام على المهاجر ، فلما استثتى الثناث دل على أنها ليست

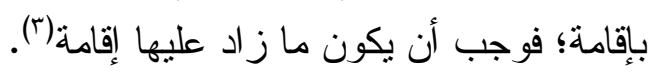
المناقثة:

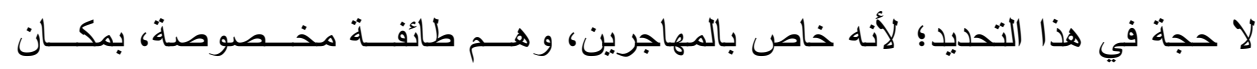

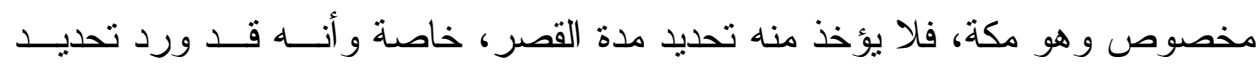

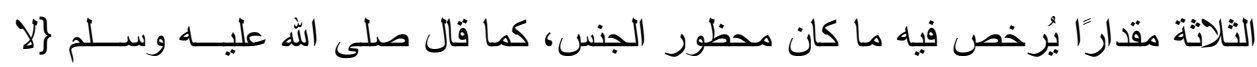

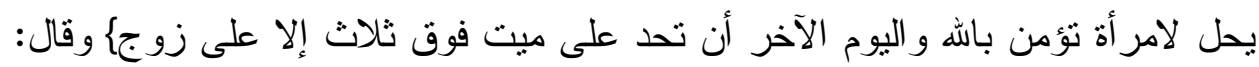

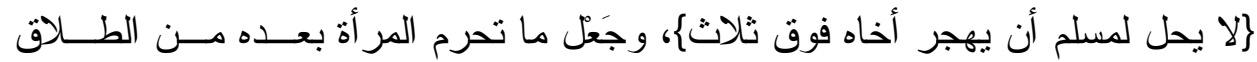
ثنالثًا (ఓ).

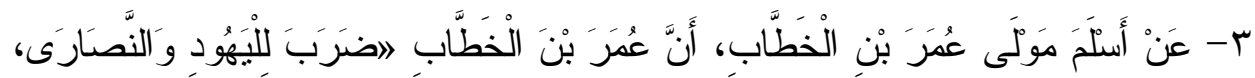

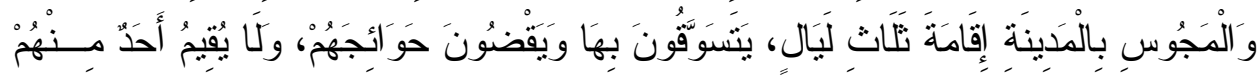

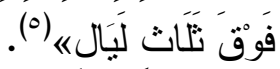

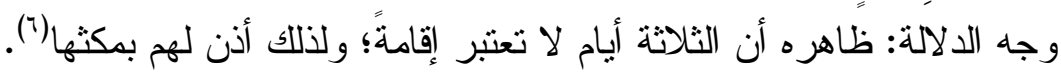

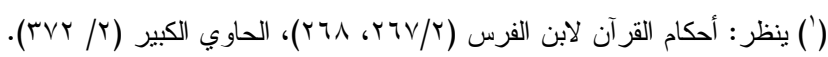

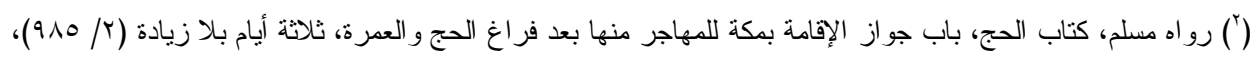
(Iror)

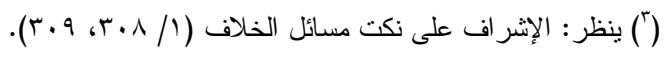

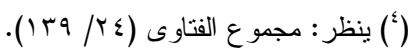

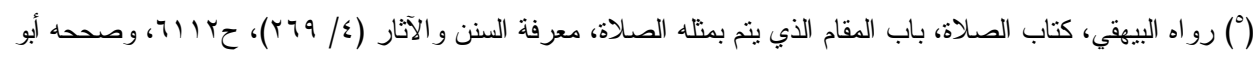

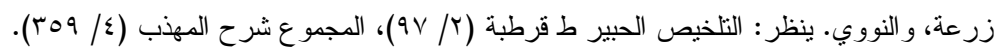

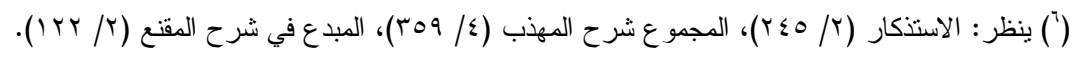




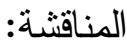

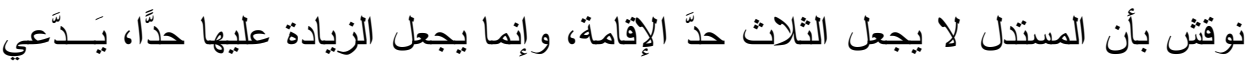

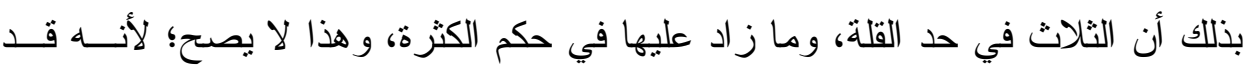

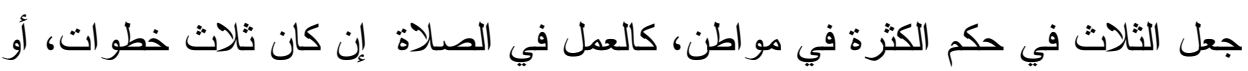

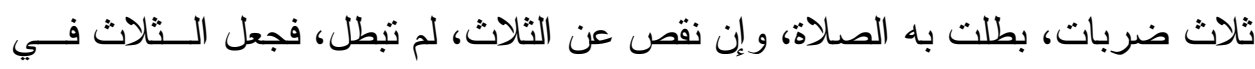

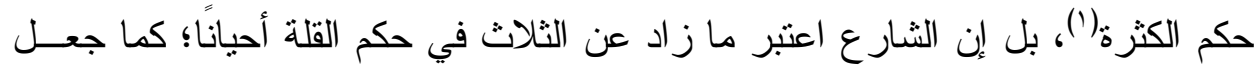

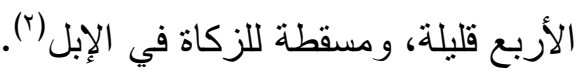

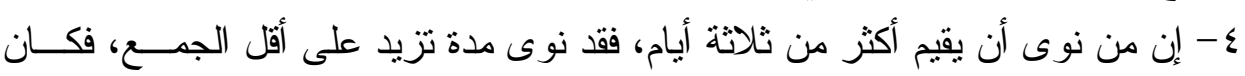

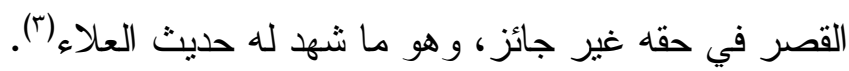

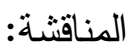

يمكن أن يجاب عنه بما سبق عن الدليل السابق.

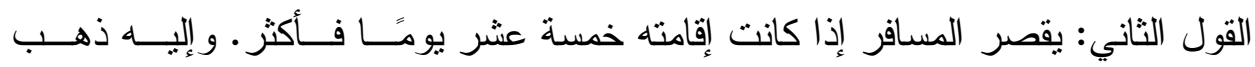

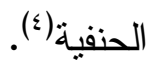
الأدلة:

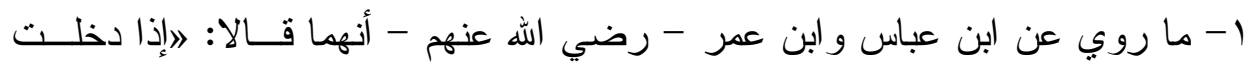

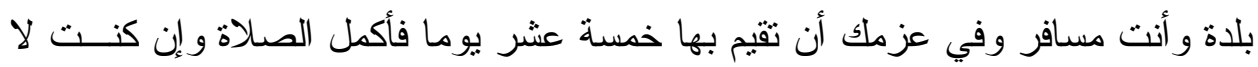

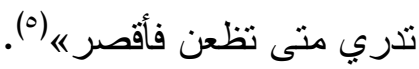

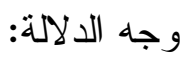

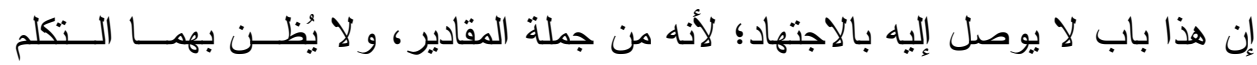

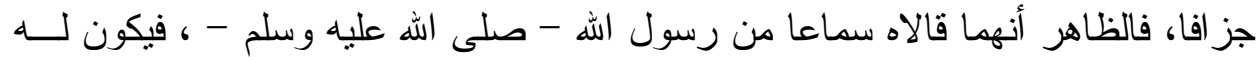

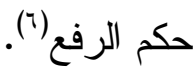

$$
\begin{aligned}
& \text { (') ينظر : نهاية المحتاج إلى شرح الهنهاج (r/ م). }
\end{aligned}
$$

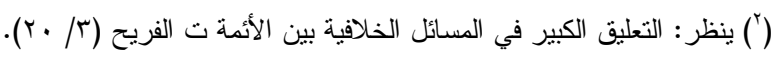

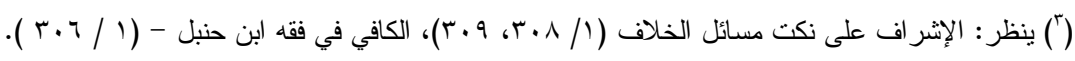

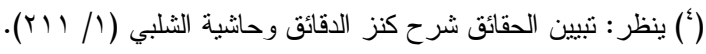

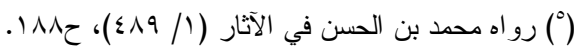

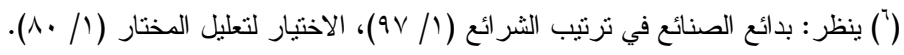


مناقشة:

نوقش بأن هذا لم يثبت عنه، بل ثبت عنه خلاف ما نقلوه عنه، و عليه فلا حجـــة فيمـــا

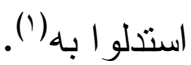
1- نوقش بأن الخصوم (الجمهور)، لا يسلمون بذللك، بل يرون جريــان القيــاس فــي

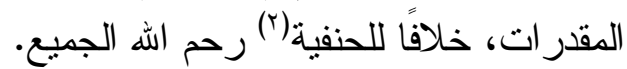

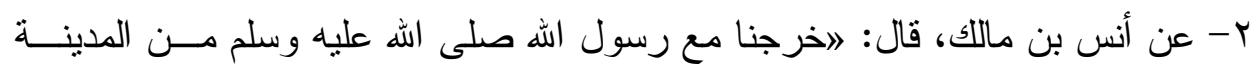

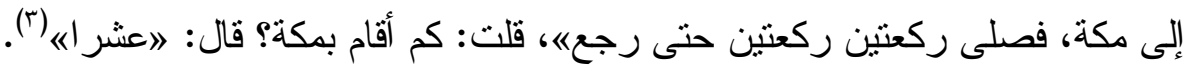

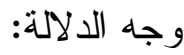

إن المسافر إذا نوى الإقامة أقل من خمسة عشر يومًا جاز له القصر (๕). المناقثشة: أجاب الإمام أحمد أن ما ورد من الحديث في حساب مدة إقامته عليه الــصلاة و الــسلام عشرًا، أنه ليس يفقهه كل أحد، وأن الصحابي الجليل حسب إجمالي مقامه عليه الصلاة

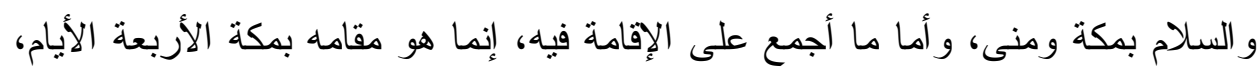
قبل توجها إلى منى (०).

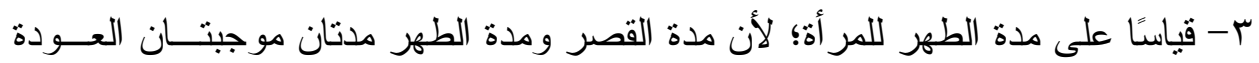

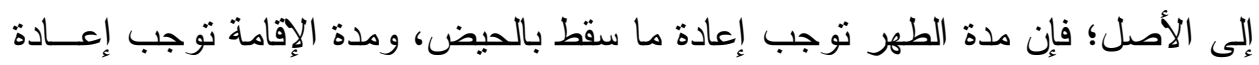
ما سقط بالسفر، فكما قدرنا مدة الطهر بخمسة عشر ، فكذلك نقدر أدنى مدة الإقامة آجأ. المناقشة:

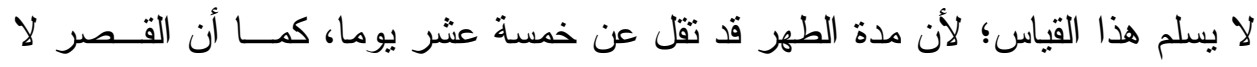

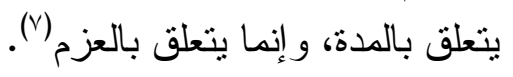

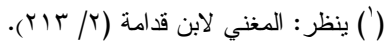

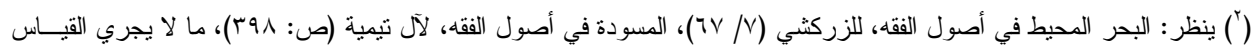

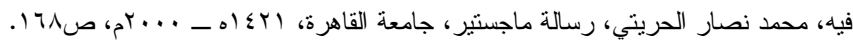

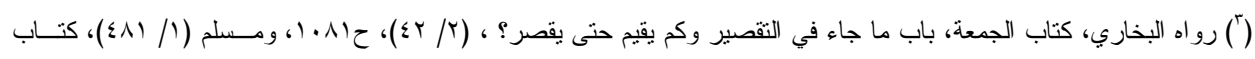

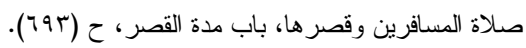

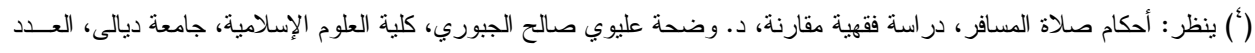

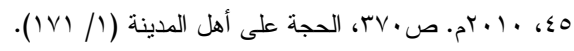

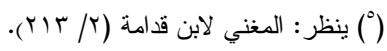

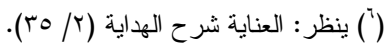

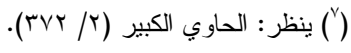




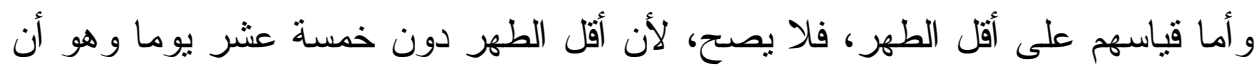

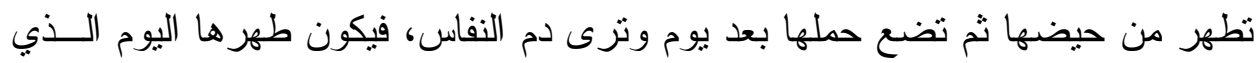

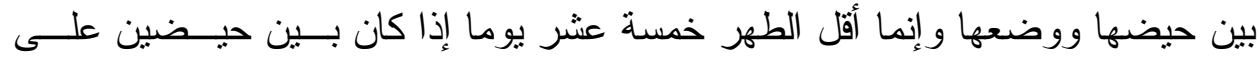

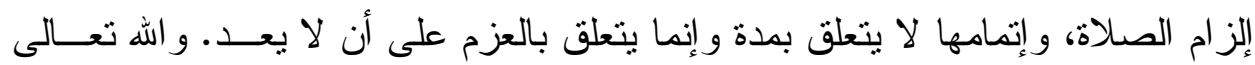

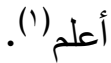

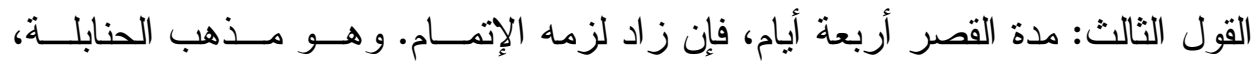

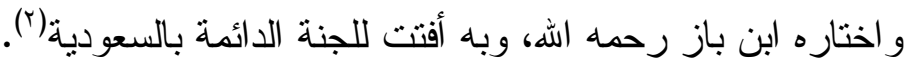

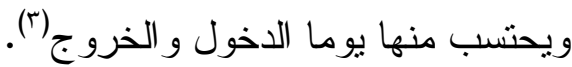

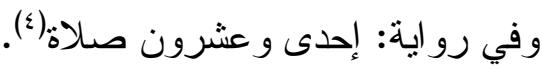
الدليل: وفي روإن

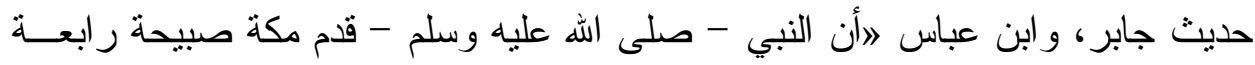

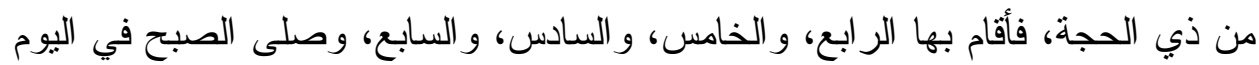

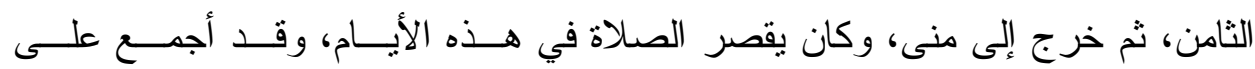
إقامتهاه (ن)

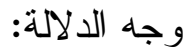
إنه فعل النبي عليه الصلاة و السلام؛ حيث أقام بمكة الر ابع و الخامس و الساد و والسابع،

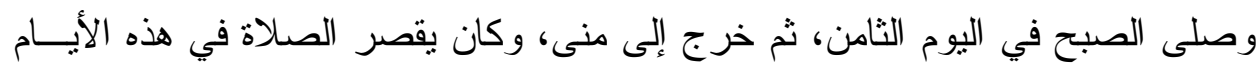

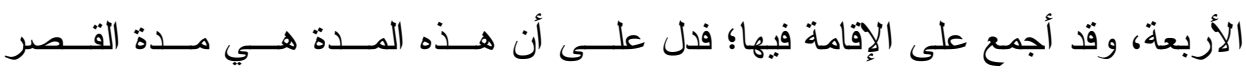

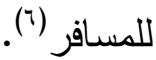

(') ينظر : المصدر السابق، الصفحة نفسها.

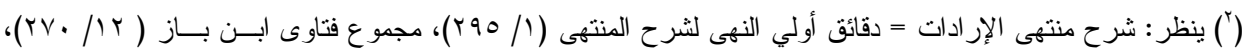

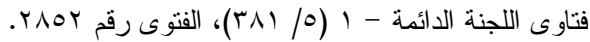

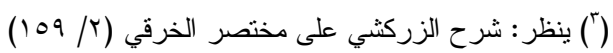

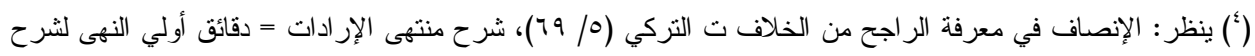

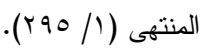

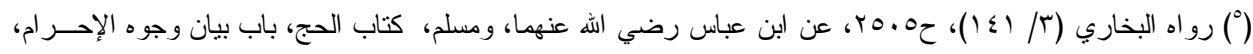

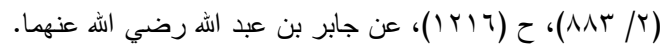

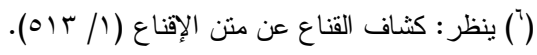




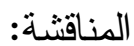

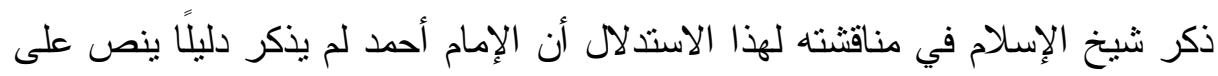

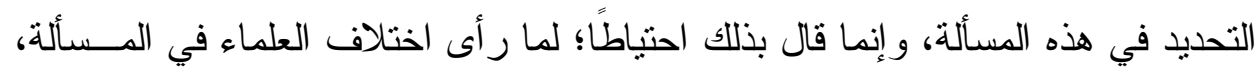

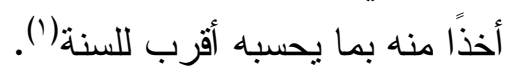

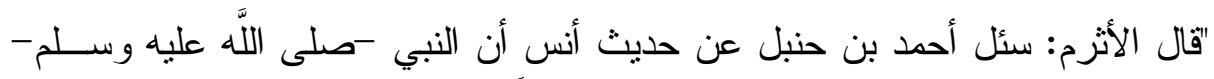

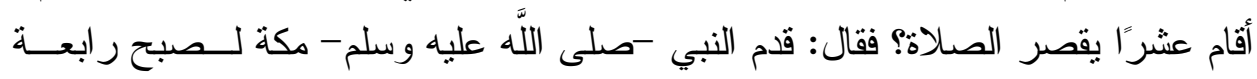

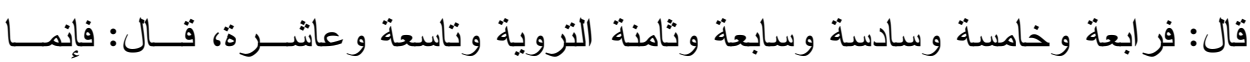

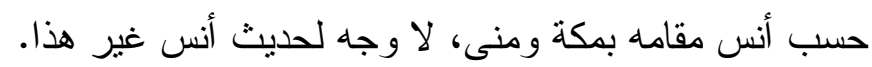

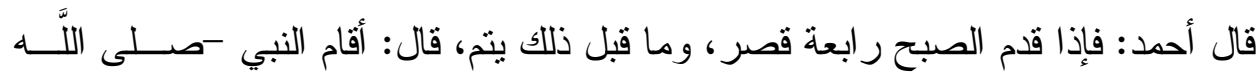

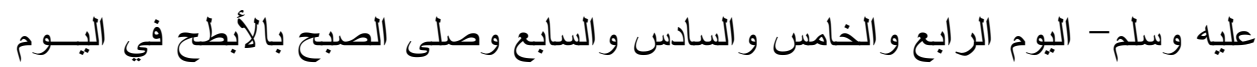

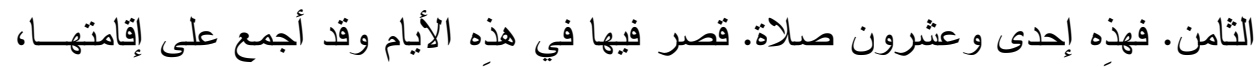

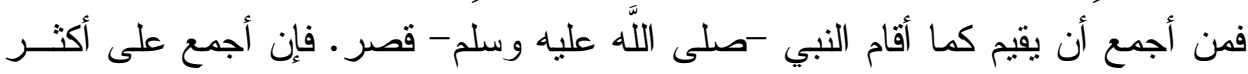
من ذلك أثن.

قلت له: فلم لا تقصر فيما زاد على ذلك؟ قال: لأنهم اختلفو ا؛ فنأخذ بالاحتياط ونتم"(؟).

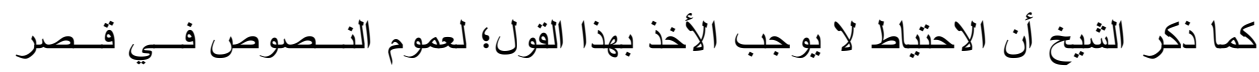

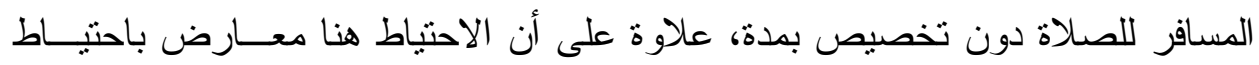

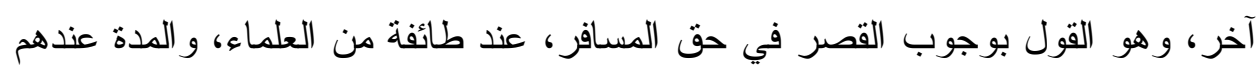

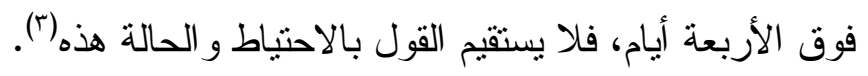

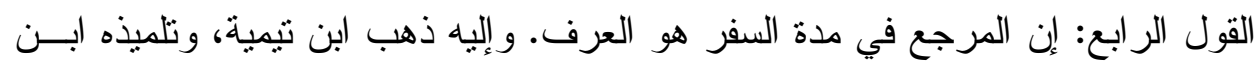
القيم (£).

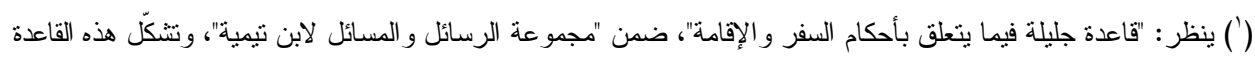

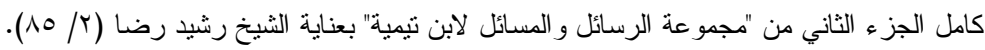

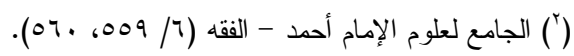

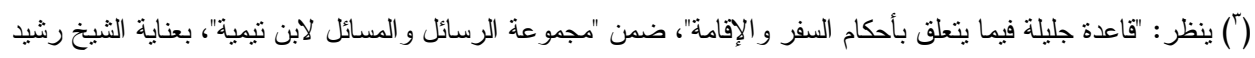

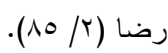

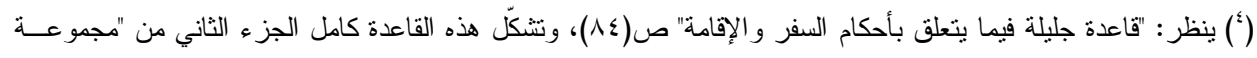

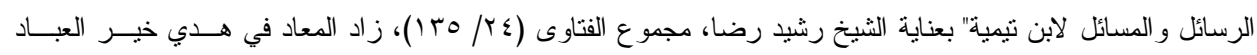


الأدلة:

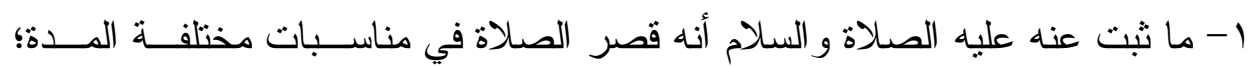

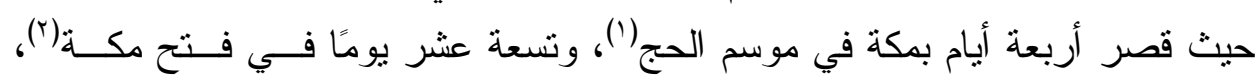

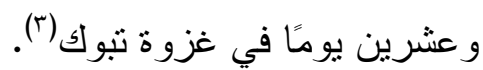

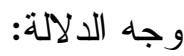

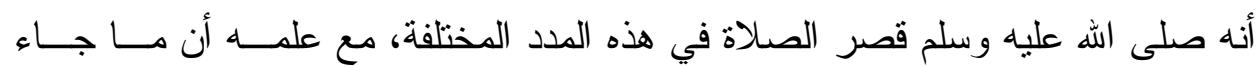

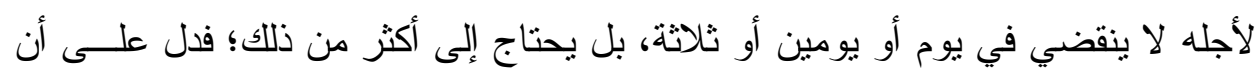

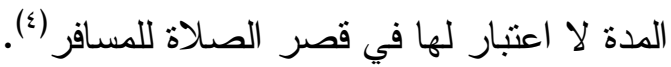
المناقشة:

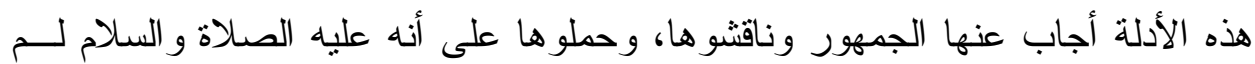

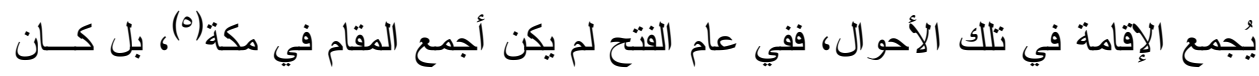
يريد المسير إلى حنين ().

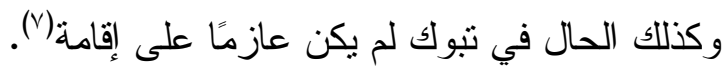

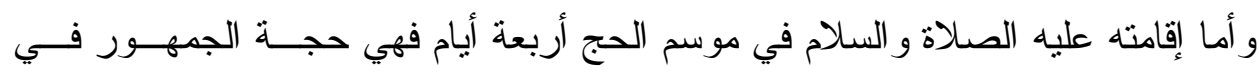
تحديد مدة إقامة المسافر (^). وقد نُقل الإجماع على أن من نوى الإقامة لزمه الإتمام(9)؛ فنبقى على هذا الأصل إلا ما

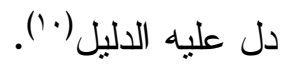

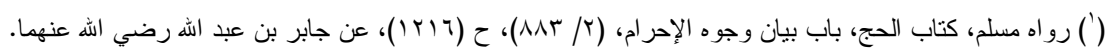

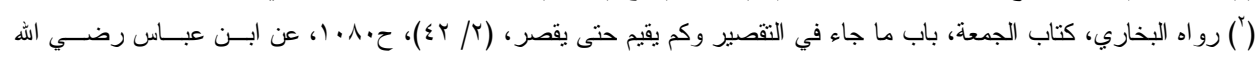

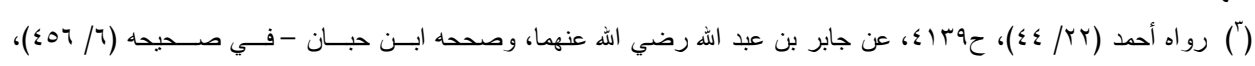

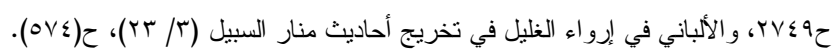

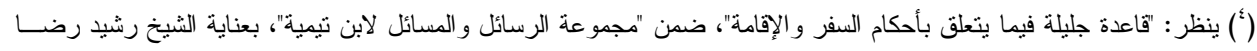

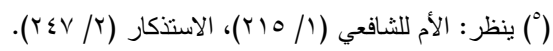

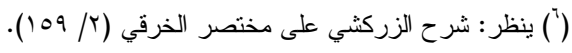

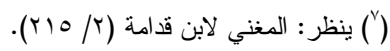

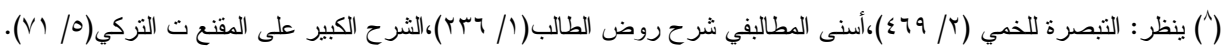

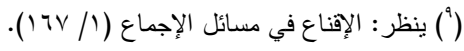

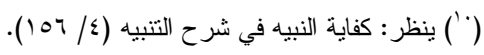




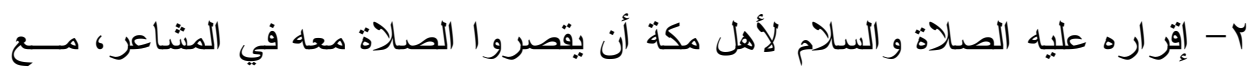

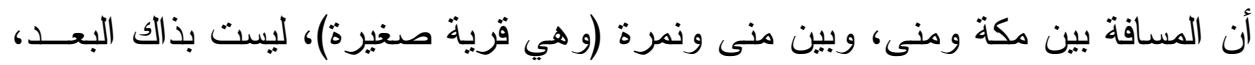

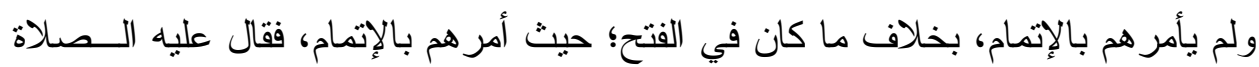

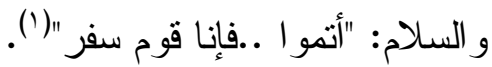
ب- فعل الصحابة، السلف وفتاو اهم، فمن ذلك الكوم:

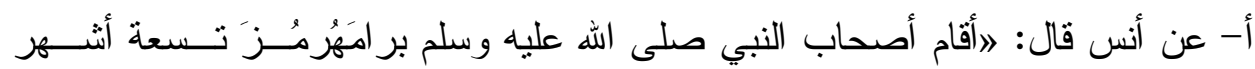
يقصرون الصلاةن) (ז). ب- عن أبي مجلز، قال: قلت: يا أبا عبد الرحمن، آتي المدينة طالب حاجة، فأقيم بهــا

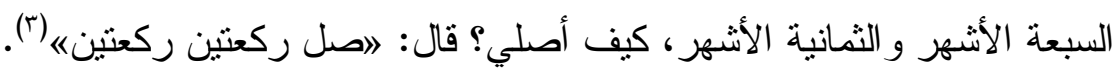

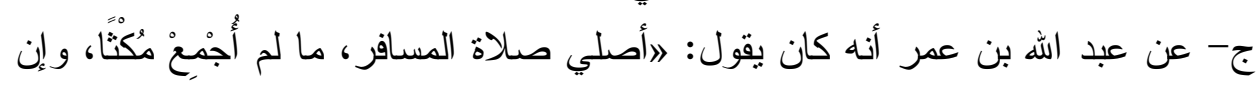
حبسني ذلك اثثتي عشرة ليلةه (๕). د- عن أبي جمرة نصر بن عمران، قال لابن عباس: إنا نطيل القيام بالغزو بخر اســان

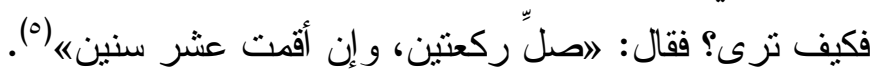

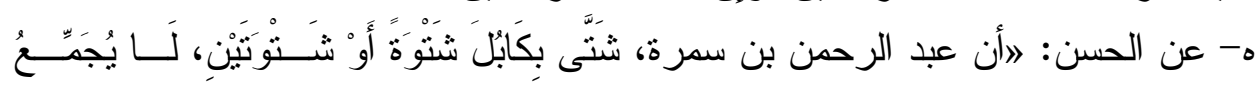
ويصلي ركعتينه(").

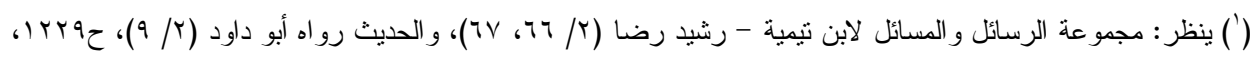

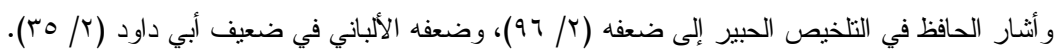

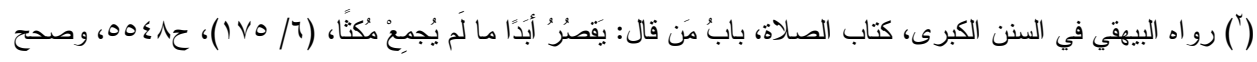

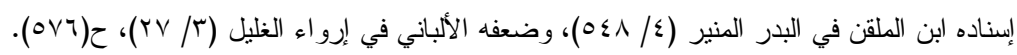

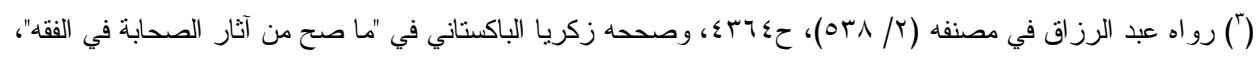
.

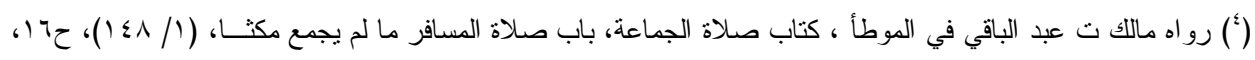

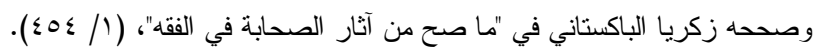

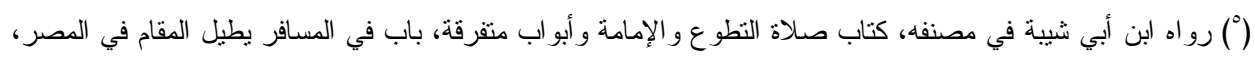

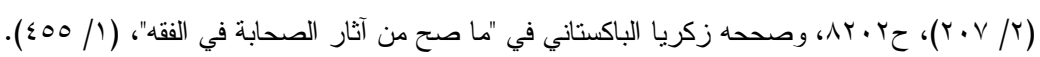

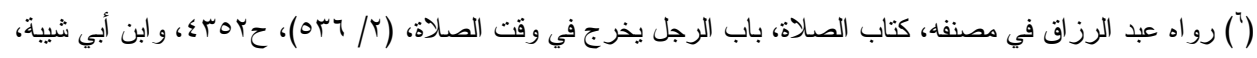

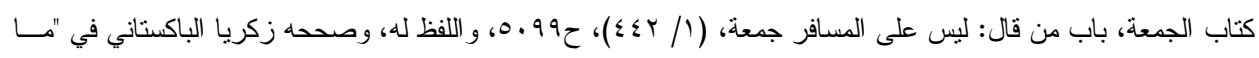

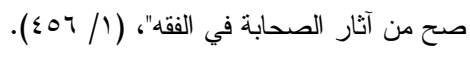




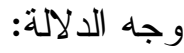

إن هذا الفعل، وهذه الفتاوى من الصحابة و السلف رضهي الله عنهم، يدل على أن المــدة ألها لا اعتبار لها في أحكام السفر (') ع - قاعدة: الأسماء المطلقة:

وقد نص عليها الفقهاء و الأصوليون، وطبقها شيخ الإسلام في مو اطن (؟)، ومسنـ كلامسـهـ رحمه الله حولها:

"وكل اسم فلا بد له من حد، فمنه ما يعلم حده باللغة؛ كالثمس و القمر و البــر و البحــر

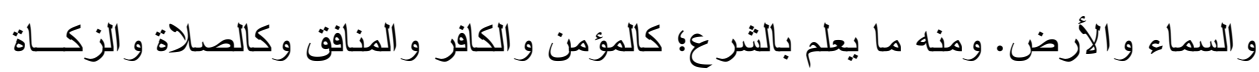

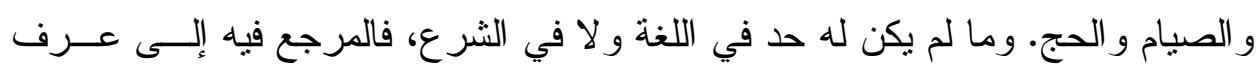

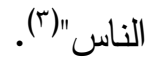
وقال في خصوص مسألنتا:

"كل اسم لبس له حد في اللغة ولا في الثرع فالمرجع فيه إلى العرف؛ فما كــان ســفر ا

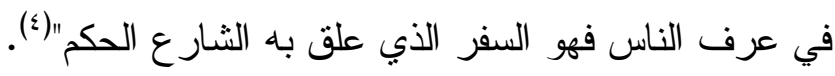

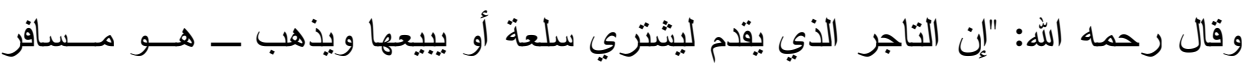

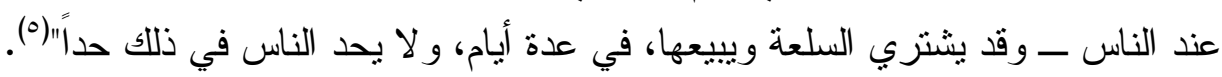
المناقثة:

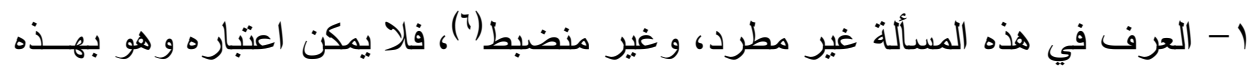
المثابة، في ركن أركان الإسلام الكبرى.

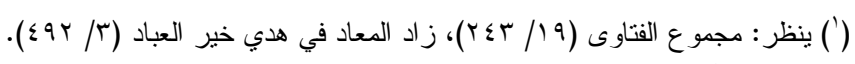

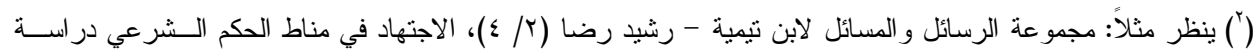

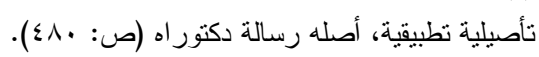

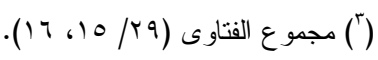

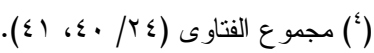

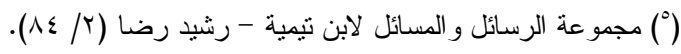

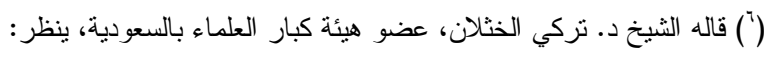
.https://saadalkhathlan.com/rrr) 
r- القول باعتبار العرف في هذا المسألة، مع عدم انضباطه، يشعر المـسلم بــالحرِّ،

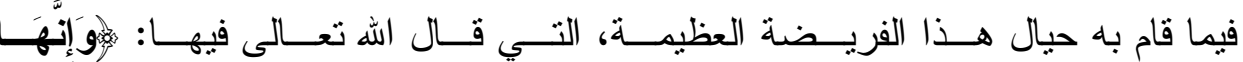

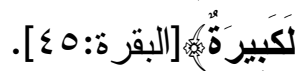

قال الثيخ ابن باز رحمه اله: "المعتمد في هذا كله هو أن الإقامة تكون أربعة أيام فأقل،

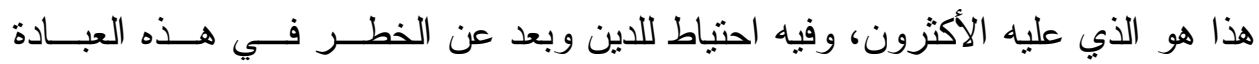

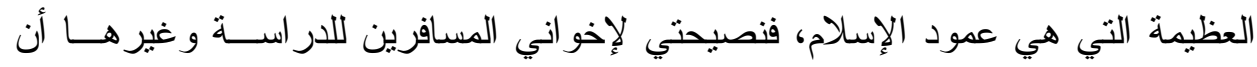

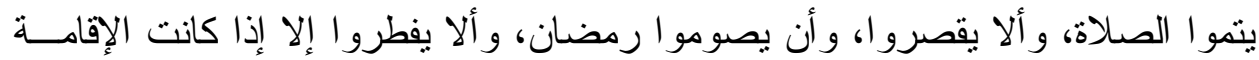

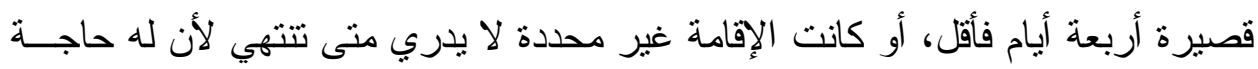

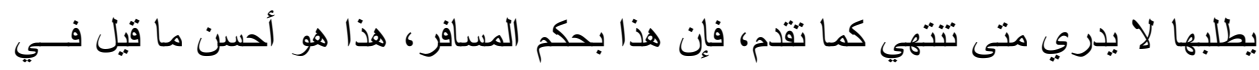

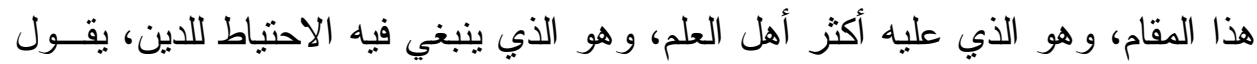

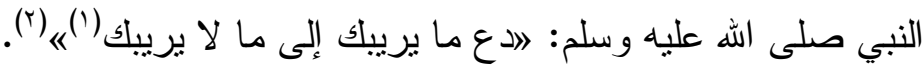

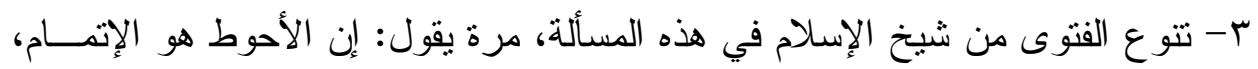

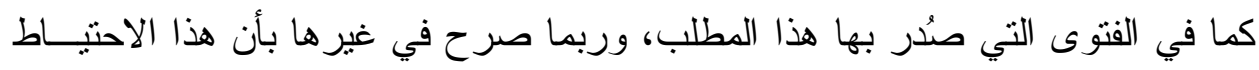

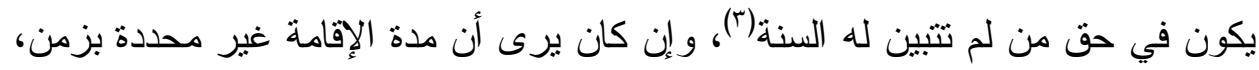
بل مرجعها إلى العرف.

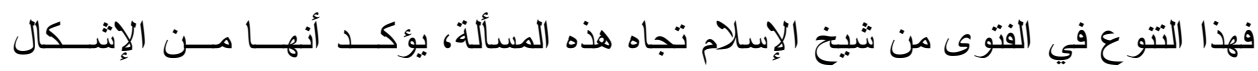

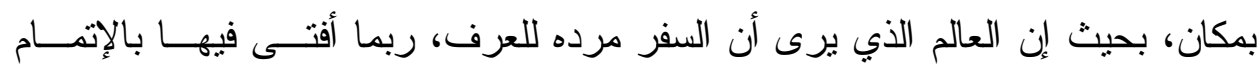
احتباطنا.

و هذا يؤكد أن الأبر أ للذمة، والأبعد عن الثبهة، هو القول بالإتمام، فيما زاد على أربعــة

\section{الموازنة بين رأي شيخ الإسلام وأقوال الفقهاء:}

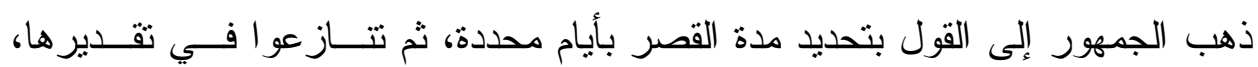

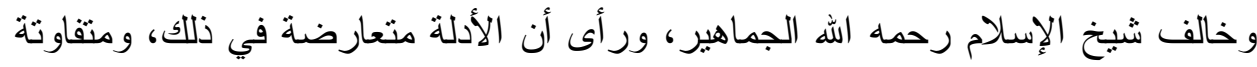

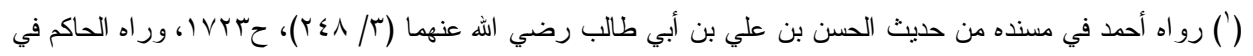

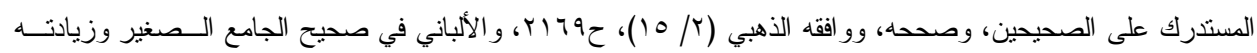




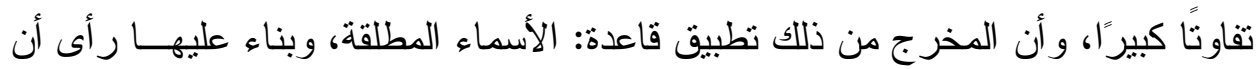

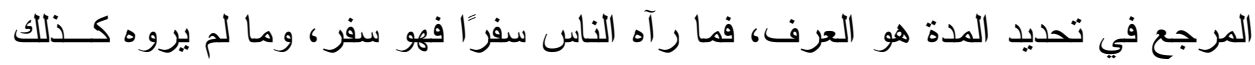

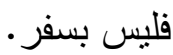
ومع ذلك فقد اختار رأي الأصحاب (الحنابلة) احتياطً؛ ربما لأن قوله أسـعد الأقـــــال

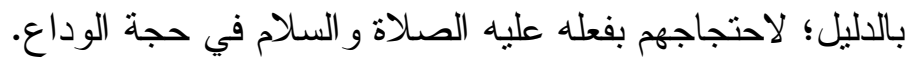

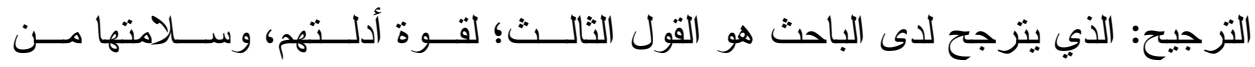

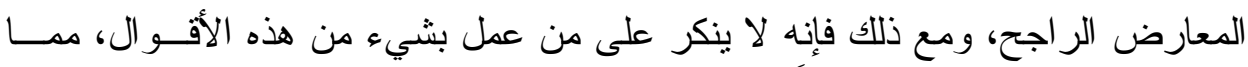

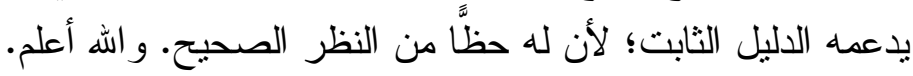

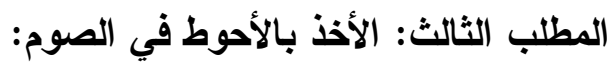

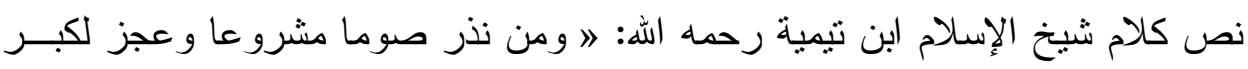

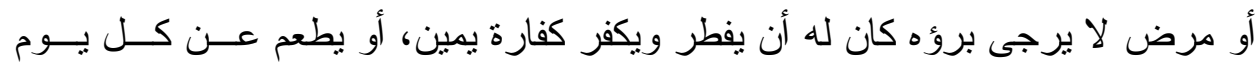

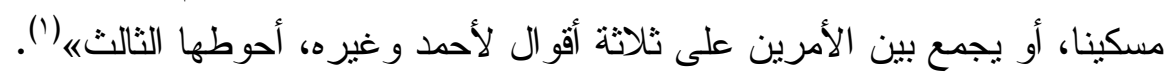

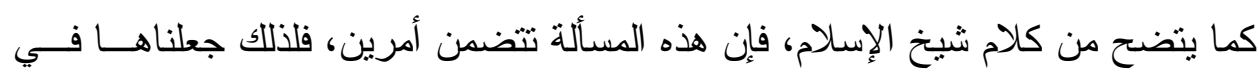

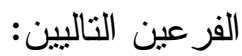

الفرع الأول: العجز عن صوم الوالين:

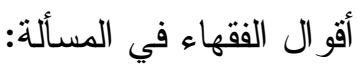

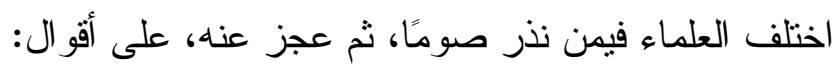

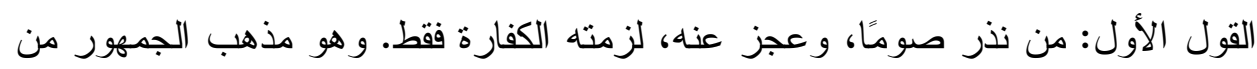

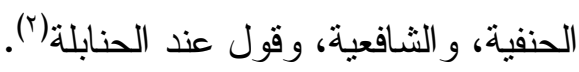
الأدلة:

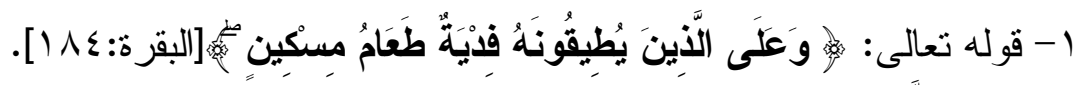

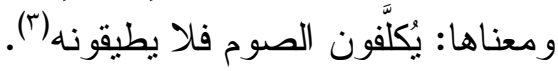

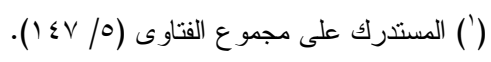

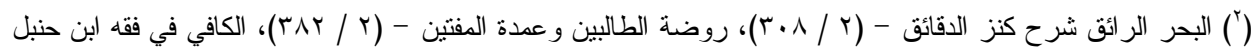




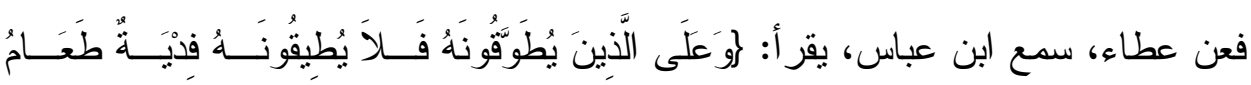

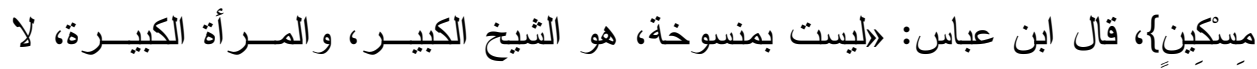
يسنطيعان أن يصو ما، فيطعمان مكان كل يوم مسكيناه (').

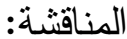

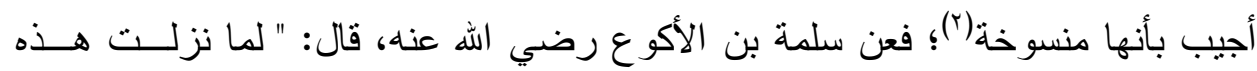

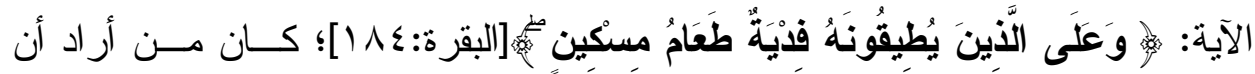
يفطر ويفتدي، حتى نزلت الآية التي بعدها فنسختها" (؟).

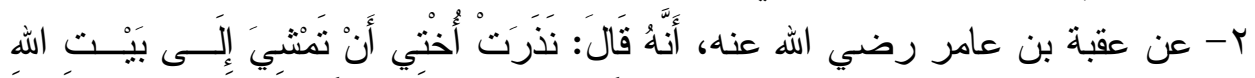

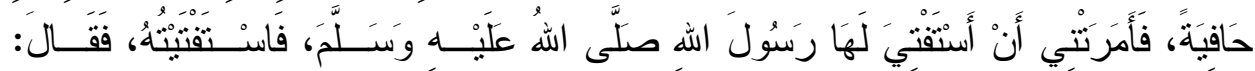

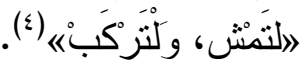

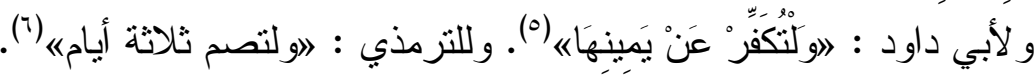

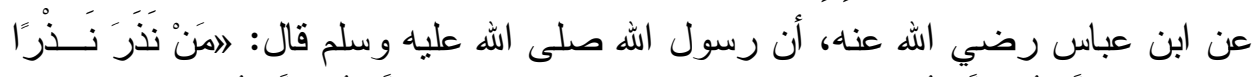

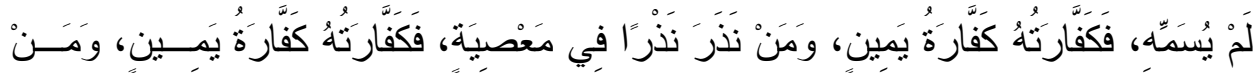

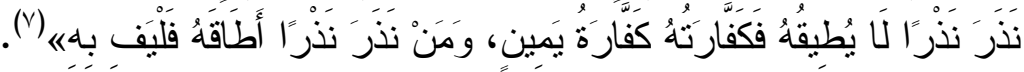

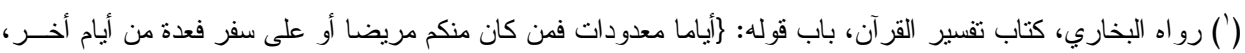

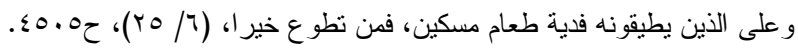

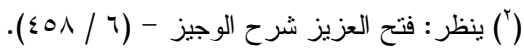

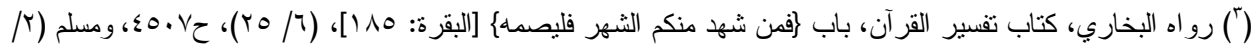

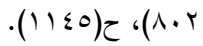

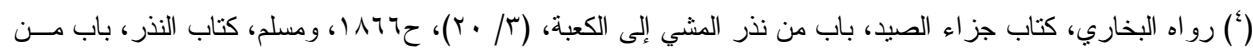

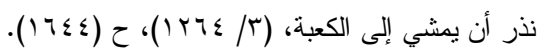

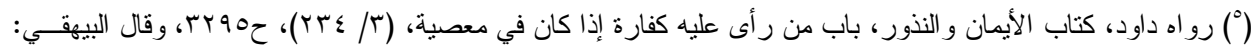

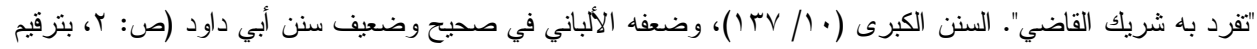

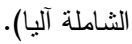

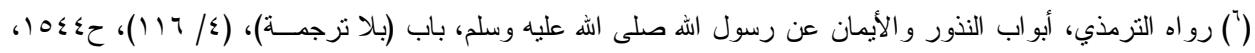

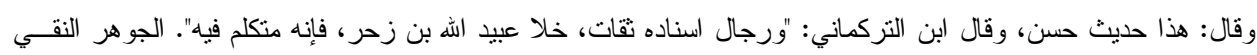

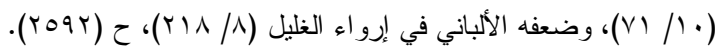

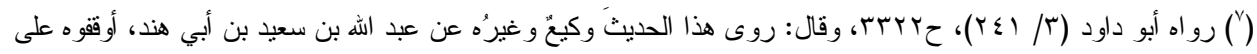

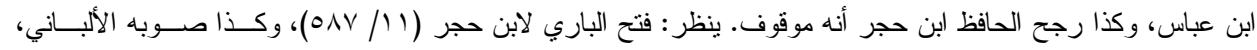

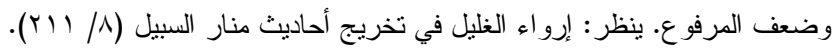


ץ- كما استدلو ا بقول الصحابي؛ حيث ورد ذلك عن علي بن أبي طالب، وابن عبـاس،

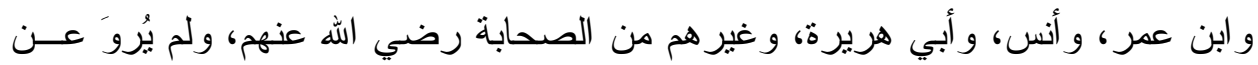
أحد سو اهم خلاف ذللك؛ فكان إجماعًا (').

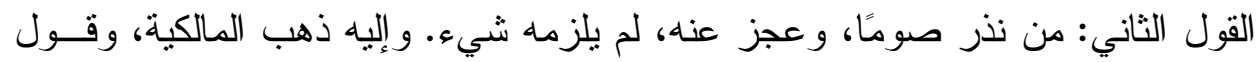
عند الحنفية و الثافعية(؟). الأدلة:

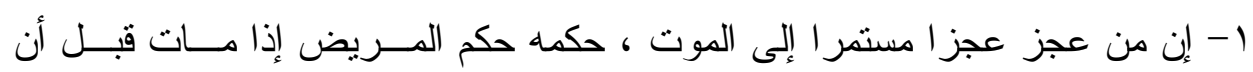

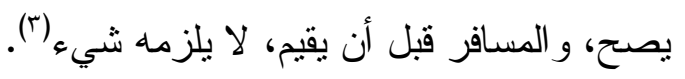

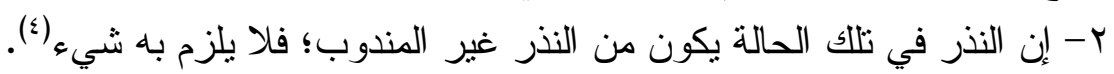

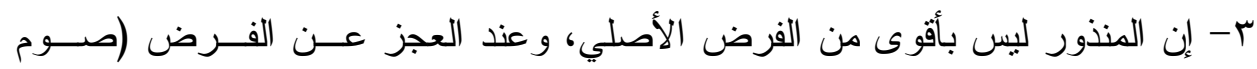

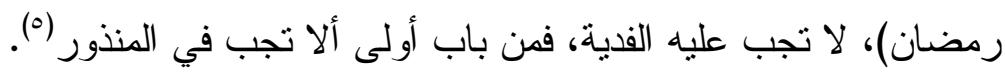

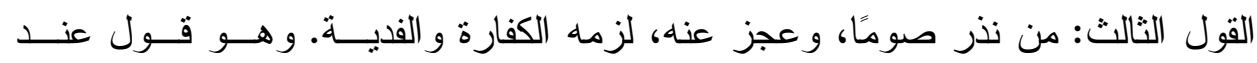
الحنابلة، اختاره ابن قدامة(؟). الأدلة:

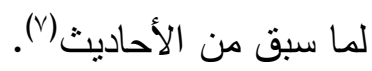

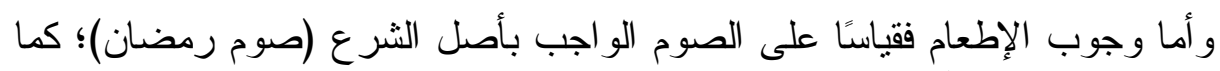

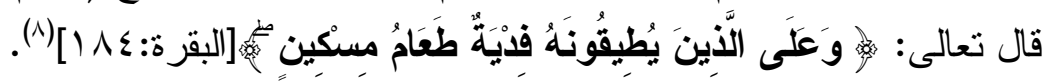

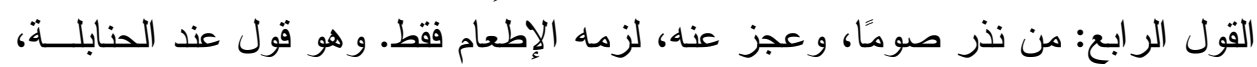

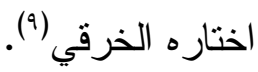

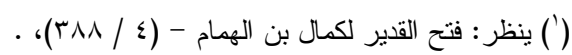

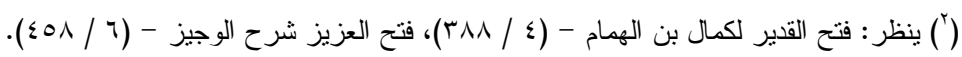

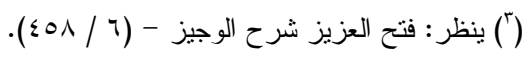

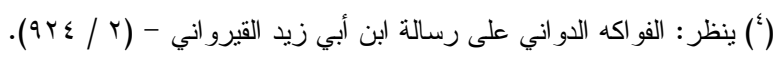

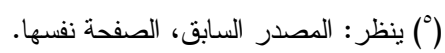

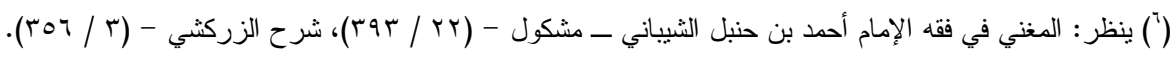

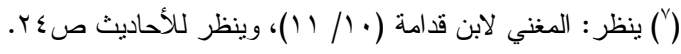

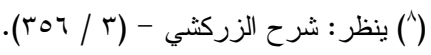

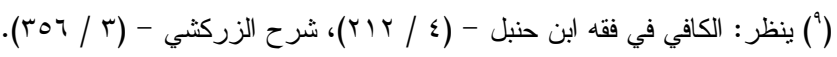


ا - قياسًا على رمضان؛ لأنه صوم وُجد سبب إيجابه عيناًا' (1). المناقثة:

لا يصح قياسه على صوم رمضان ؛ لوجهين:

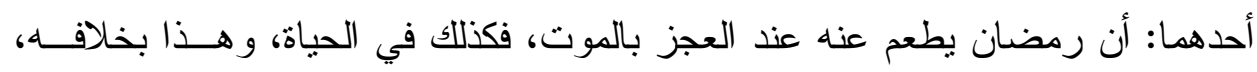

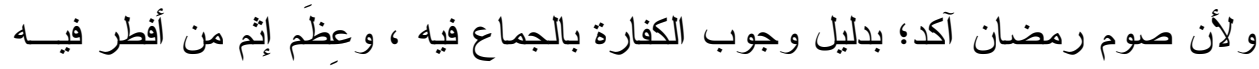

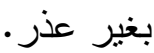

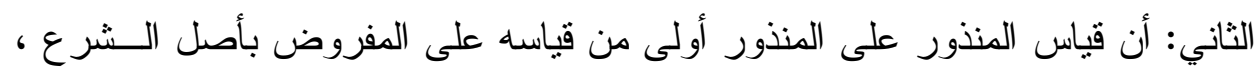

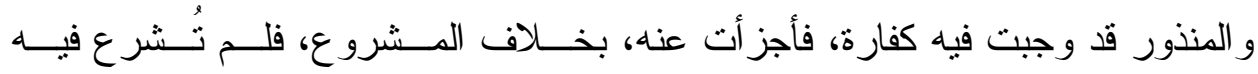
(ب) الكفارة) ץ- إن المطلق من كلام الآدميين يحمل على المعهود شرعا ، ولو عجز عــن الــصوم

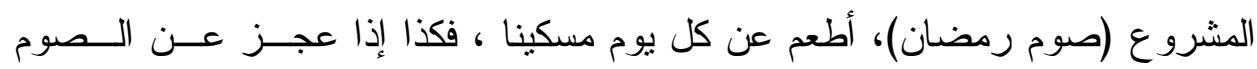

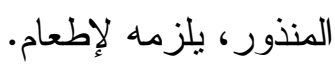

المناقثة: إن هذا ليس بمطلق، و إنما هو منذور معين، تكفي فيه الكفارة("). المو ازنة بين رأي شيخ الإسلام و أقو ال الفقهاء:

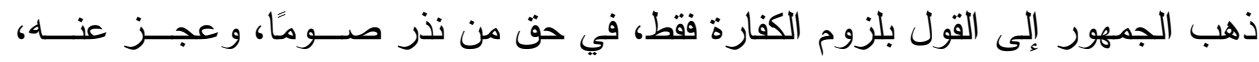
و هناك أقو ال منباينة في المسألة، ومال شيخ الإسلام ابن تيمية إلى أن الاحتياط في المسألة، هو الأخذ بقول مــن

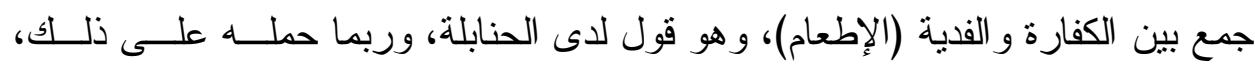

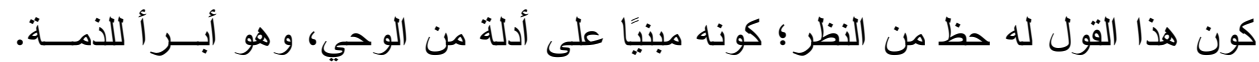
و الله أعلم. كون. هذان.

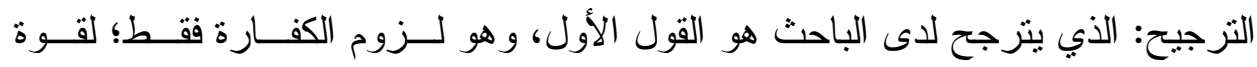

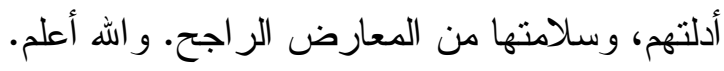

\footnotetext{
(') (') ينظر ، المغني لابن قدامة (· (1) (1). (') ينظر : المصدر السابق، الصفحة نفسها. (") ينظر : المصدر السابق، الصفحة نفسها.
} 
الفرع الثاني: الأخذ بالأحوط في الفصد في الصوم:

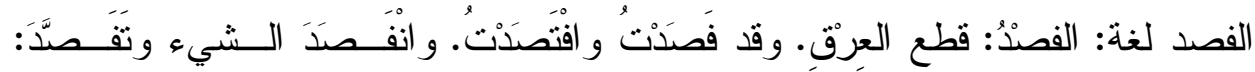

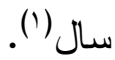

واصطلاحًا: الفصد: إجر اء الدم من العرق(؟). نص كلام شيخ الإسلام ابن تيمية رحمه الله: 》 وسئل - رحمه الله تعالى - -

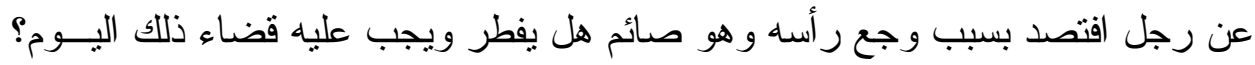

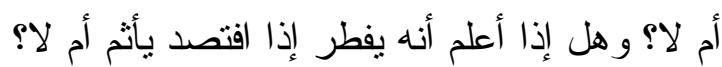
فأجاب: الحمد لله، هذه المسألة فيها نز اع في مذهب أحمد وغيره و الأحوط أنه يقضي ذلك اليوم.

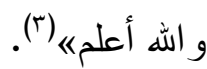
أقو ال الفقهاء في المسألة: تتازع العلماء في حكم الفصد، على أقو ال:

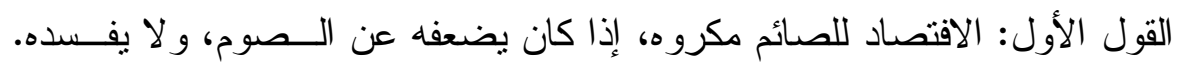

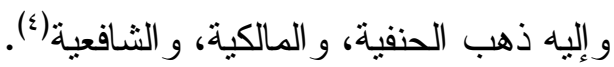
وقال بعض الثافعية: بل هو خلاف الأولى (o). الدليل: 1- إن الفصد يضعف المفصود عن الصوم، ويعرض صومه للفساد(؟).

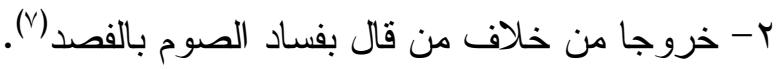

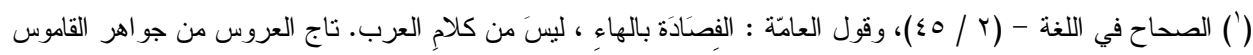
. $(\varepsilon 9 \wedge / \wedge)-$ () و ومثله: البزغ، لكن الفصد مختص بالآدمي، و البزغ بالبهائم. ينظر : دسنور العلماء أو جامع العلوم في اصطلاحات الفنون $.(170 / 1)-$

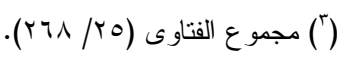

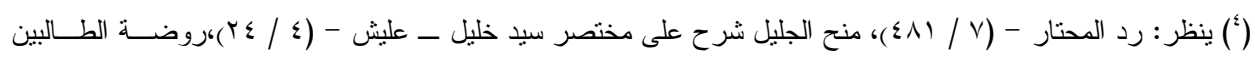

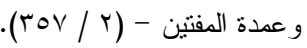

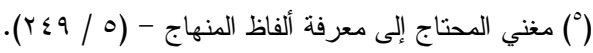

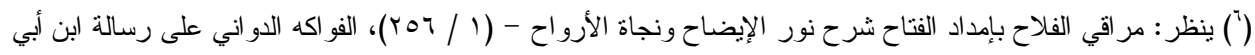

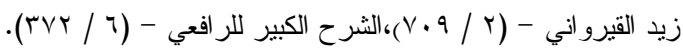

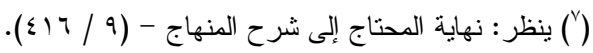


القول الثاني: يباح للصائم الفصد، من غير كر اهة. و إليه ذهب الحنابلة('). الدليل:

إن القياس لا يقتضي إحاقه بالحجامة؛ إذ إن القول بإفساد الحجامة للصوم تعبدي.

و هذا مبني على رأيهم في إفساد الصوم بالحجامة، خلافا للجمهور (؟).

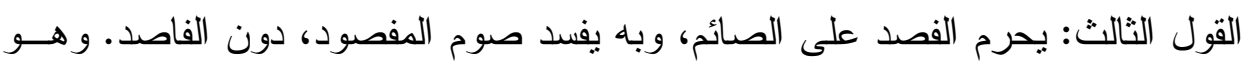

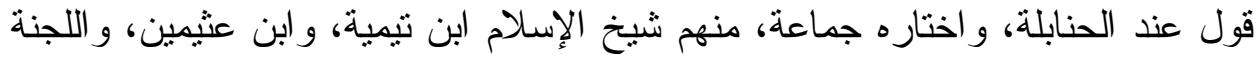

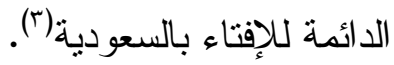
الاليل:

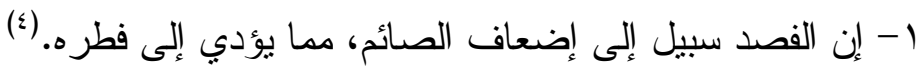

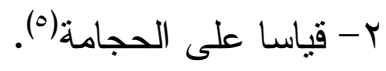
المناقثنة:

لو سلمنا بأن الفصد يضعف الجسد، فإن الأقرب أنه لا يفسد الصوم، و الحجامة نفسـها،

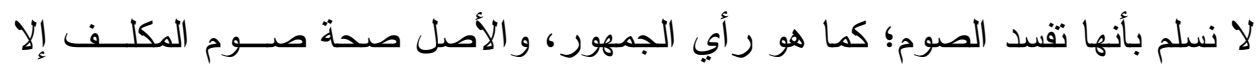

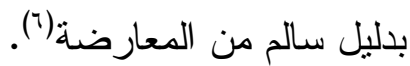
المو ازنة بين رأي شيخ الإسلام و أقو ال الفقهاء: لدئ

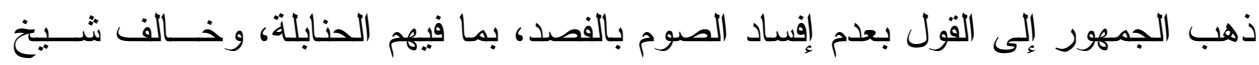

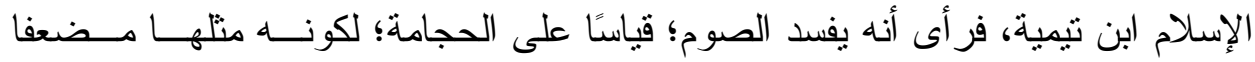
للجسم.

التزجيح: الذي يترجح لدى الباحث هو القول الأول، وهو كر اهة الفصد، عنــد خـشية

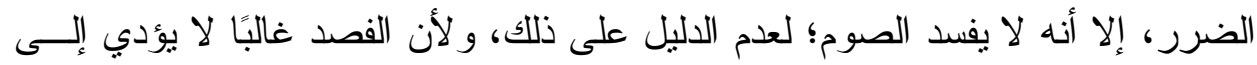

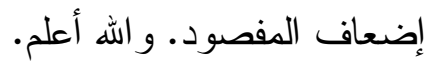

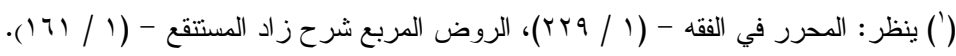

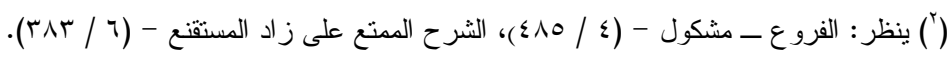

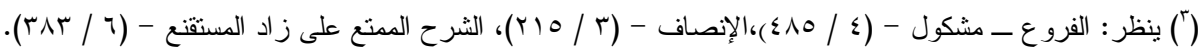

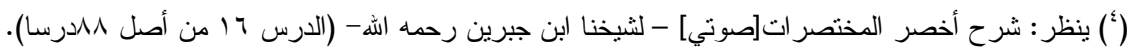

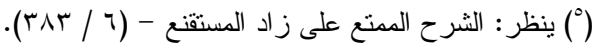

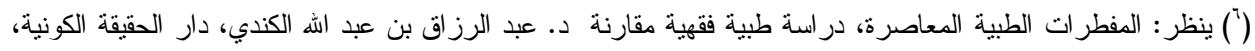


المبحث الثاني: الأحكام المتعلقة بالأخذ بالأحوط في المعاملات، وتحته ثلاثة مطالب: المطلب الأول: الأخذ بالأحوط في توكيل الأمي في قبول نكاح المسلمة: بالاجئ

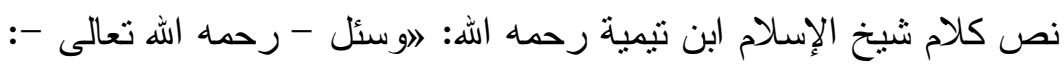

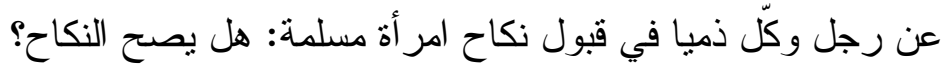
فأجاب:

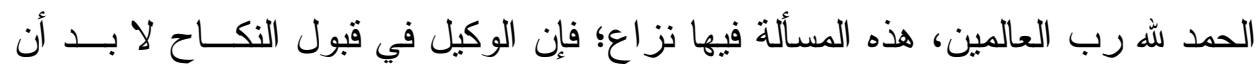

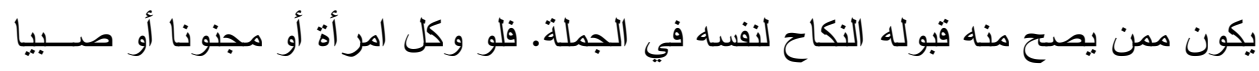

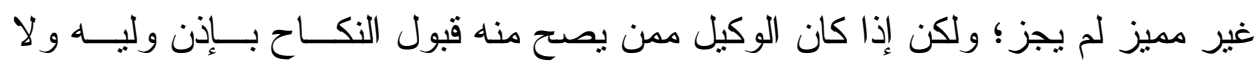

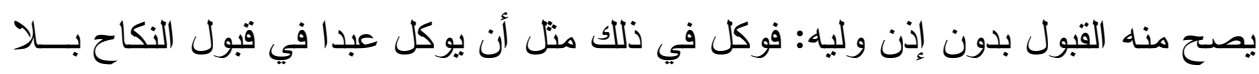

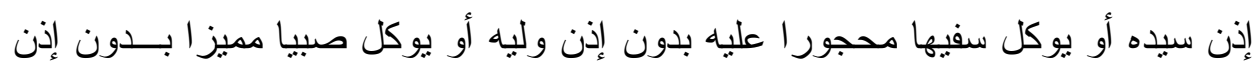

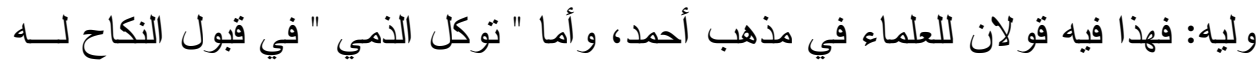

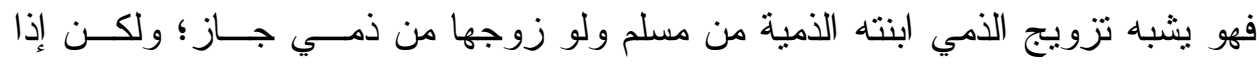

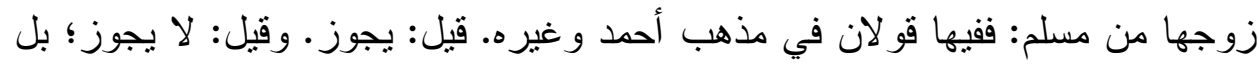

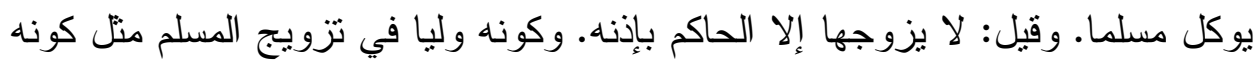

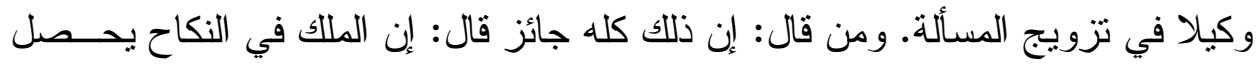

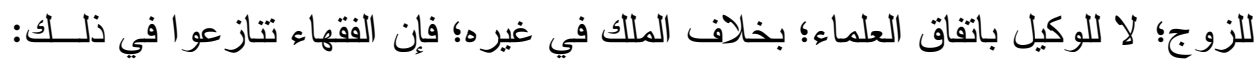

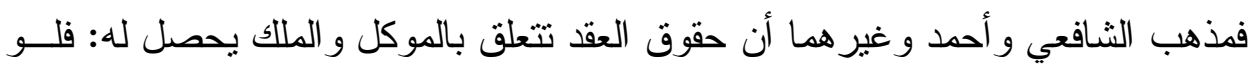

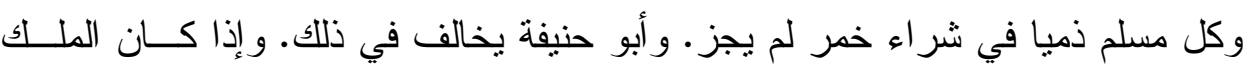

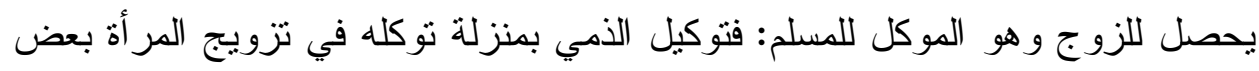

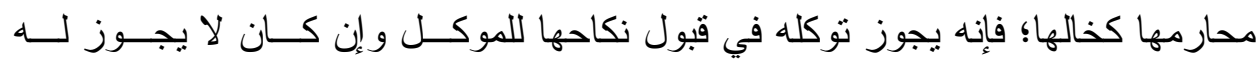

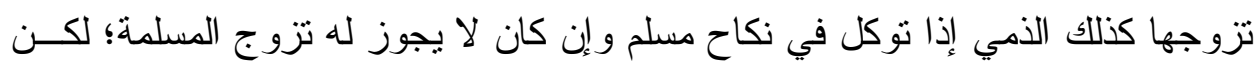

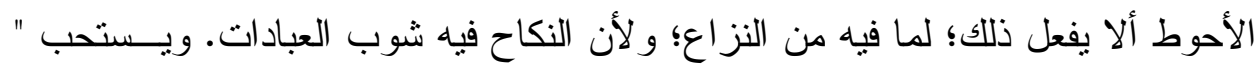

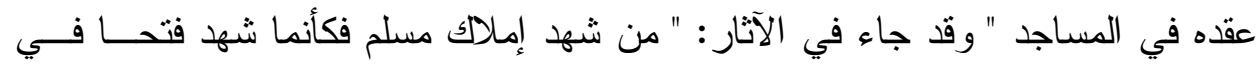
سبيل الله ". ولهذا وجب في أحد القولين مذهب أحمد وغيره أن يعقد بالعربية كالأذكـار

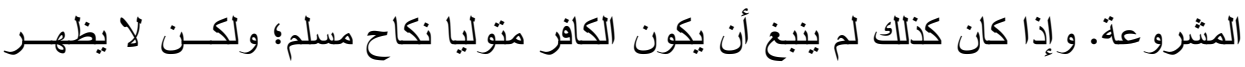


مع ذلك أن العقد باطل؛ فإنه ليس على بطلانه دليل شرعي؛ و الكافر يصح منه النكــاح وليس هو من أهل العبادات. و الهه أعلمه" ('). أقو ال الفقهاء في المسألة:

اختلف الفقهاء في حكم توكيل المسلم ذميا، يقبل له النكاح من مسلمة، على قولين:

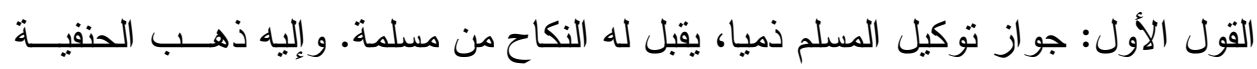

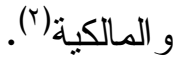
الدليل:

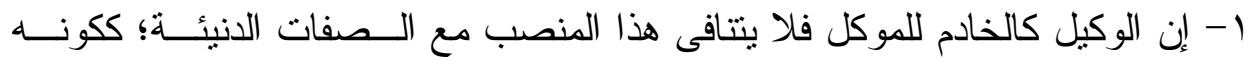

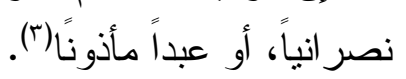

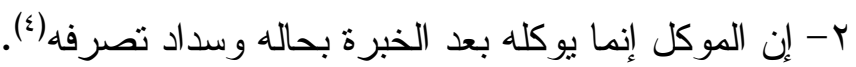

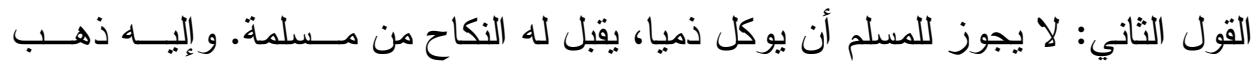
الثافعية و الحنابلة(0). الدليل: - n

إن الذمي لا يملك قبول النكاح من المسلمة لنفسه بحال، فلم يصح منه التوكل فيه(؟).

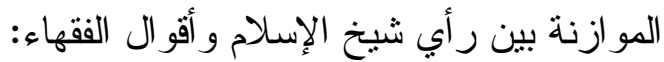

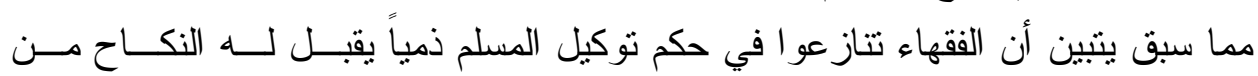
مسلمة.

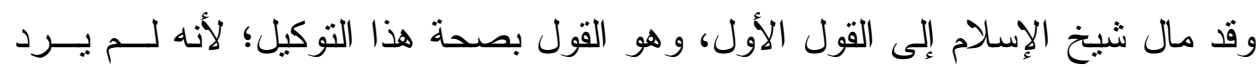
نص صحيح يفيد اثنتر اط الإسلام في وكيل النكاح.

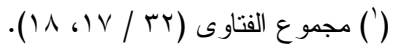

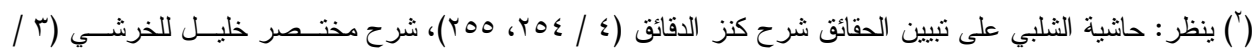

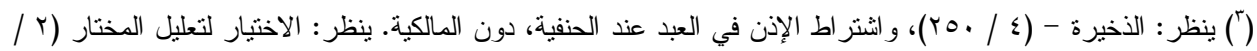

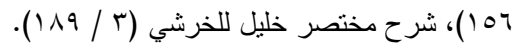

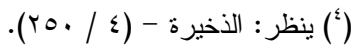

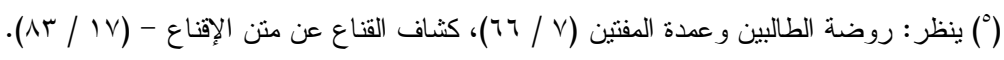

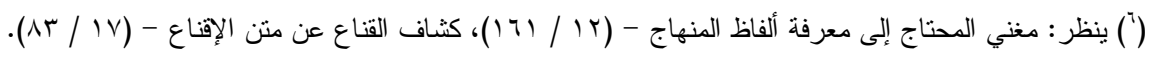


ومع ذلك فقد رأى الثيخ الاحتباط في ذلك، وأن لا يوكل المسلم ذميا يقبل له نكاحه مـن مسلمة.

التزجيح: الذي يثرجح لدى الباحث هو القول الثاني، و أنه يشترط كون الوكيل مـسلمًا؛

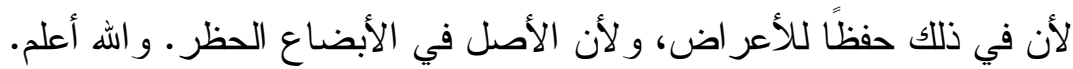
المطلب الثاني: الأخذ بالأحوط في الظهار: الظهار من الزوجة البائن:

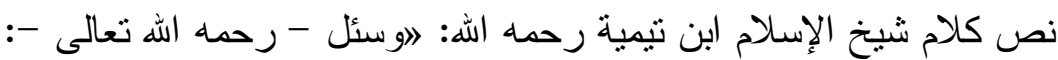

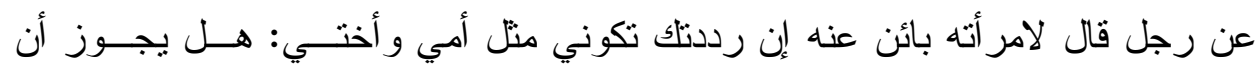
يردها؟ وما الذي يجب عليه؟

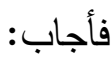

في أحد قولي العلماء عليه كفارة ظهــار و إذا ردهـــا فـي الآخـر لا شــيء. و الأول

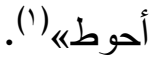

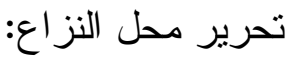
اتفق الفقهاء على أن المطقة البائن، لا يحلقها ظهار ؛ لعدم وجود محله، وهـــو العـصمة

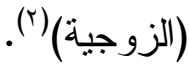
ثم تتازعوا في حكم تعليق الظهار على النكاح، وهو المسألة التي أثنــار إليهـــا الــشيخ، على قولين: - ملم: القول الأول: إذا علق الرجل الظهار من امر أة، على الزواج منها، صـح ظهاره، ولزمـــهـ الكفارة قبل الوطء. و إليه ذهب جمهور الفقهاء، من الحنفية، و المالكية، و الحنابلة(؟).

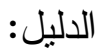
1- عن القاسم بن محمد: أن رجلا جعل امر أة عليه كظهر أمه إن تزوجها، فسأل عمر بن الخطاب، فقال: 》إن تزوجها فلا يقربها حتى يكفر هاء).

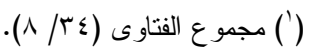

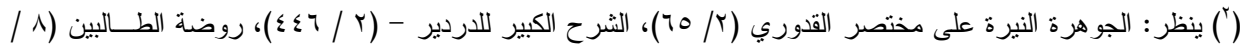

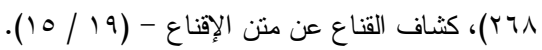

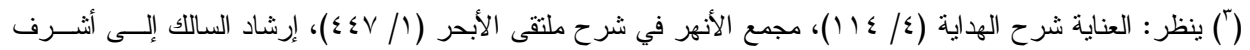

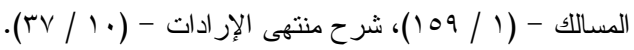

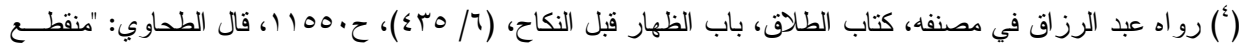

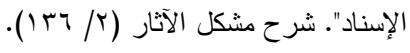


المناقثنة:

ونوقش بأنه خبر منقطع؛ القاسم بن محمد لم يدرك عمــر بـن الخطــاب ـرضــي الله

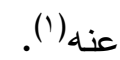

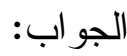

وأجيب بأنه ثبت من وجه آخر (؟).

ץ- إن الظهار يمين مكفرة؛ فصح عقدها قبل النكاح، كاليمين باله تعالى (َ). المناقثنة:

سلمنا بأنها يمين، لكنها يمين ورد الثر ع بحكمها، مقيدة بنسائه؛ فلا يثبت حكمهــا فـي

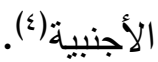

r- إن كفارة الظهار وجبت لقول المنكر و الزورر، فلا يختص ذلك بنسائه(0).

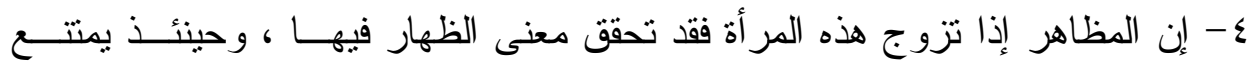

وطؤها قبل التكفير (ج). القول الثاني: إذا علق الرجل الظهار من امر أة، على الزو اج منها، لم يلحقهــــا ظهــاره.

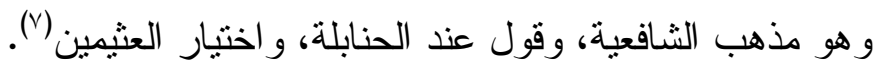
الدليل:

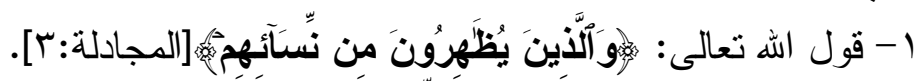

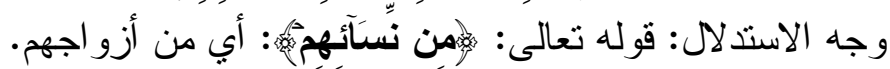

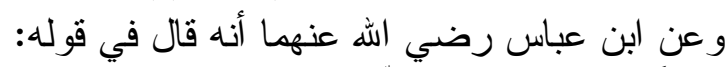

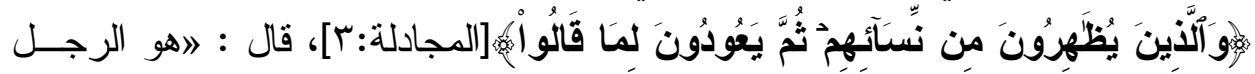

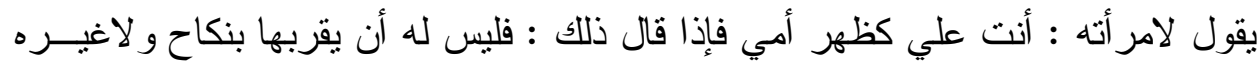
حتى يكفر .. «.الخبر (^).

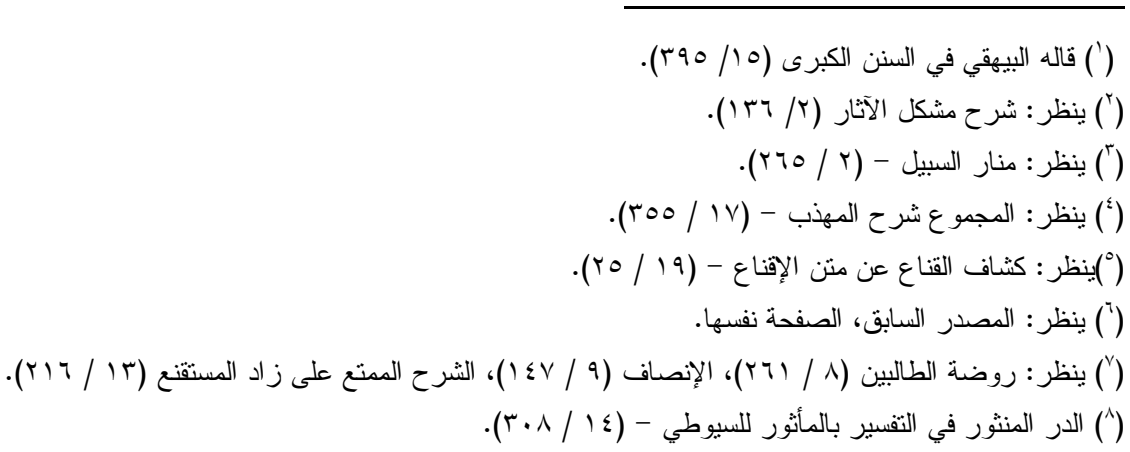


قالو ا: وهذه المر أة تعد أجنبية، ليست بامر أة له(').

المناقثة:

نوقش بأن الآية خرجت مخرج الغالب، فـإن الغالــب أن الظهــار لا يكـون إلا مــن

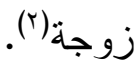

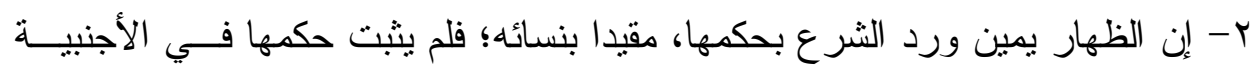

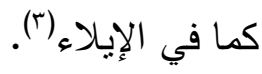

ץ- إن هذه المر أة ليست بزوجة؛ فلم يصح الظهار منها، كما لم يصح من أمته(؛).

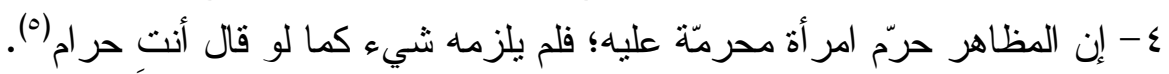

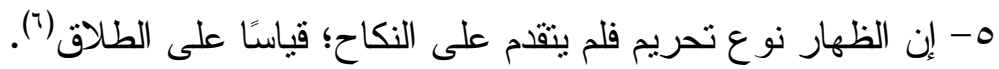
المناقشة:

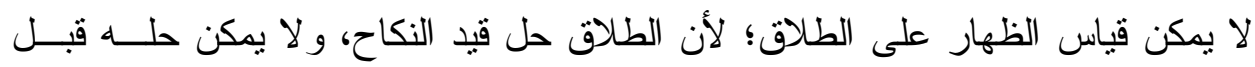

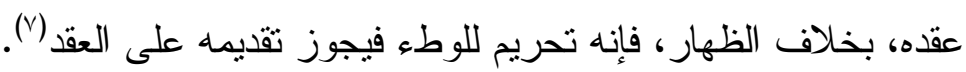

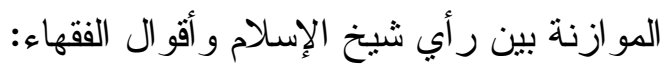

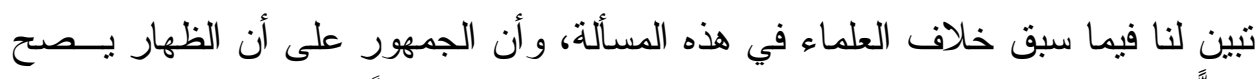

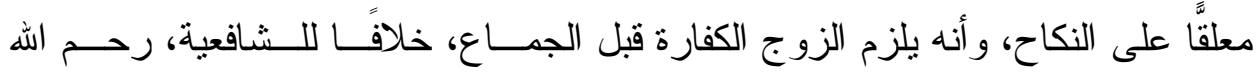

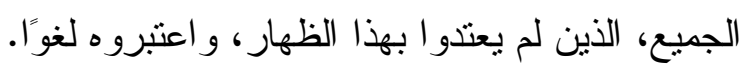

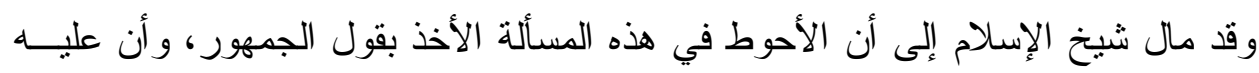

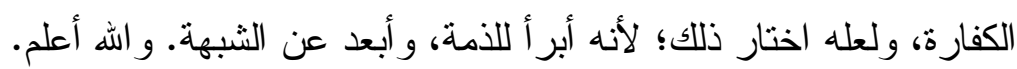

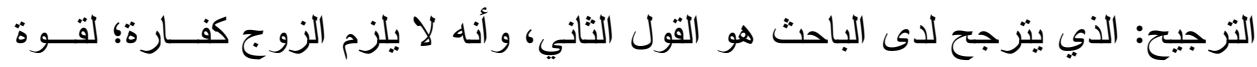

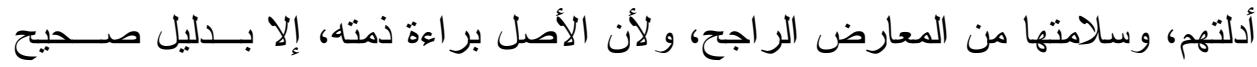

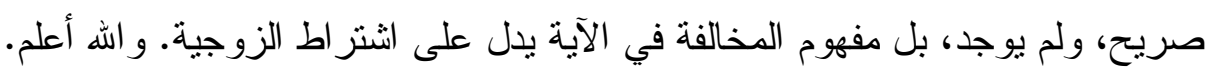

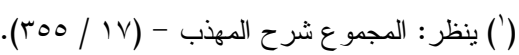

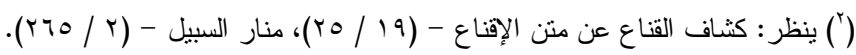

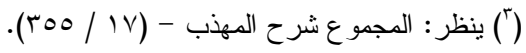

$$
\begin{aligned}
& \text { () (") ينظر : الكصدر السابق، الصفحة نفسها. } \\
& \text { (") ينظر : الصصدر السابق، الصفحة نفسها. }
\end{aligned}
$$

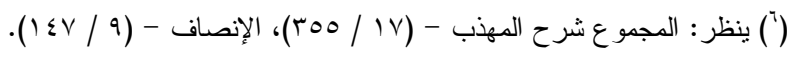

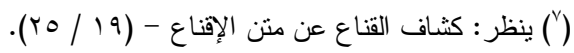


المطلب الثالث: الأخذ بالأحوط في القتل دفاعًا عن العرض:

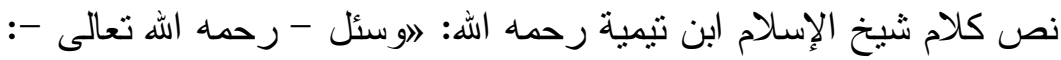

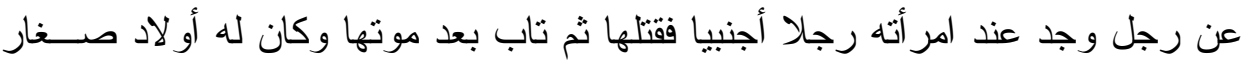

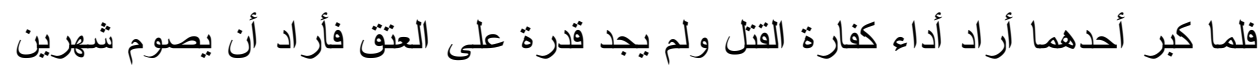

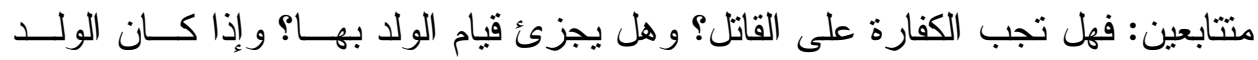

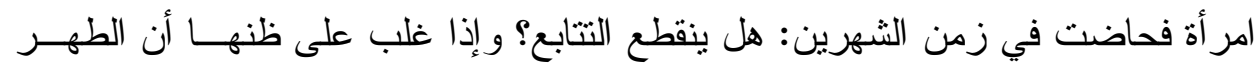
يحصل في وقت معين: هل يجب عليها الإمساك أم لا؟ فأجاب:

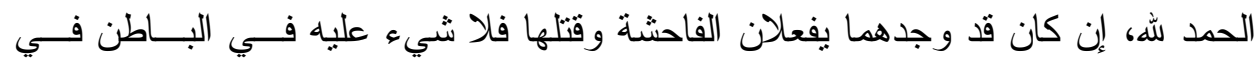

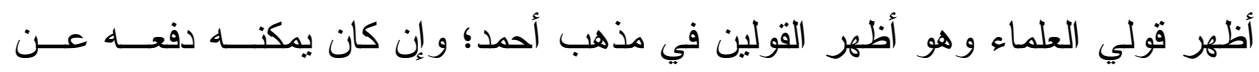

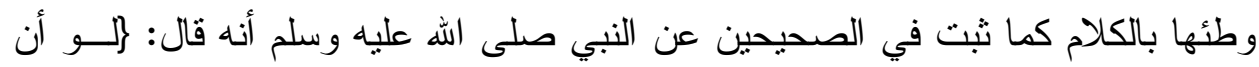

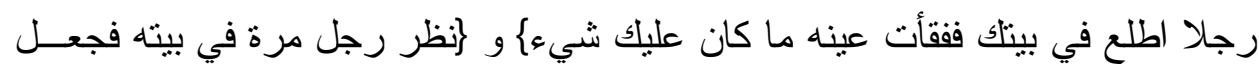

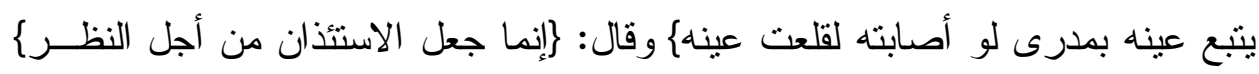

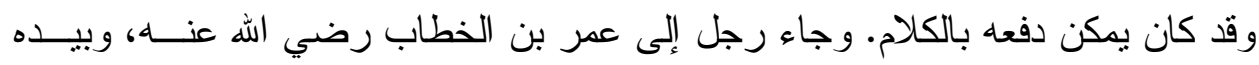

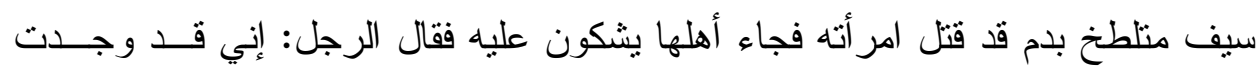

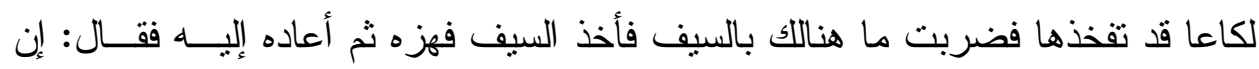

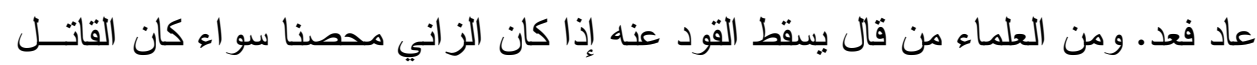

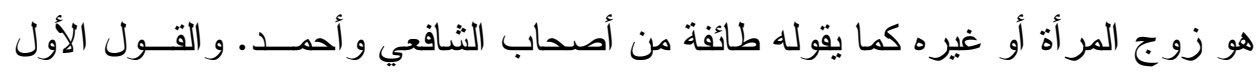

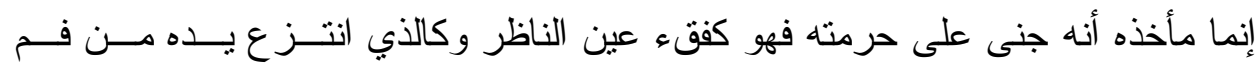

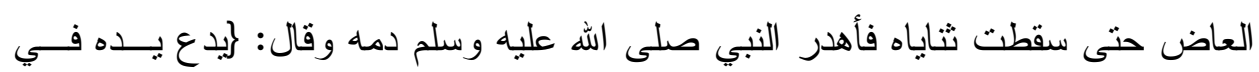

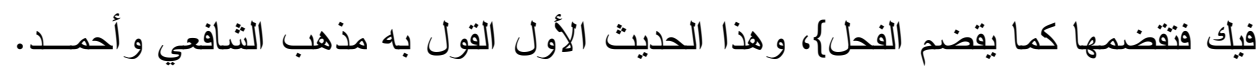

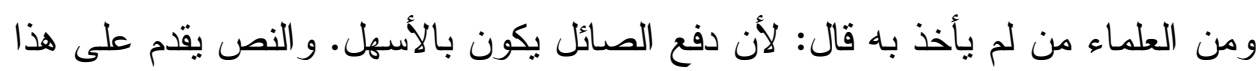

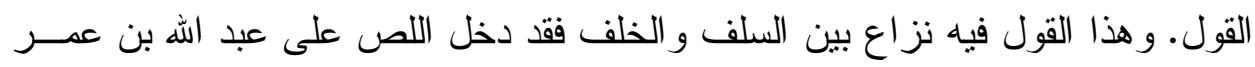

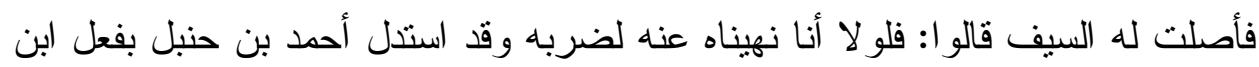

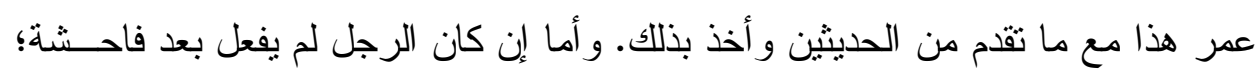

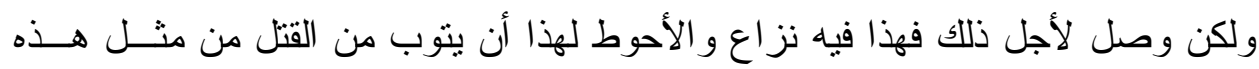


الصورة وفي وجوب الكفارة عليه نزاع فإذا كفر فقد فعل الأحوط؛ فإن الكفــارة تجــب في قتل الخطأه (') كما يتضح من كلام شيخ الإسلام، فإن هذه المسألة تتضمن أمرين، فلذلك جعلناهــا فـي الفرعين التاليين: - الفان الفرع الأول: الأخذ بالأحوط في القتل للثرف: كلام الفقهاء في المسألة: أجمع الفقهاء على مشروعية دفع الصائل على العرض، و أنه إن لم يندفع إلا بالقتل فلـــه

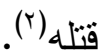
و اختلفو ا فيمن وجد رجلا مع امر أته، خاليا بها، ولم يرَّ الزنا أو دو اعيه، هل للــزوج أن يقتلهما، على قولين: القول الأول: لا يشرع للزوج قتل الزئل الزوجة و الرجل الذي معها، إلا إذا وجدهما متلبـسين

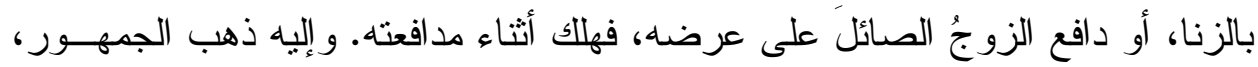

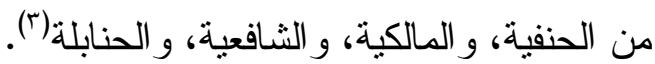

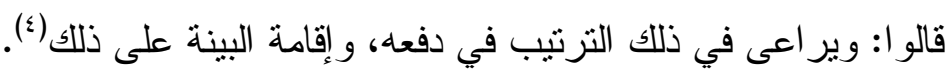

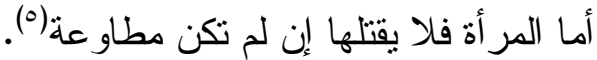
قال البهوتي رحمه الله: "( و إذا وجد رجلا يزني بامر أته فقتلهما فلا قصاص عليه ، و لا دية ) رو اه سعيد عـن الهـ

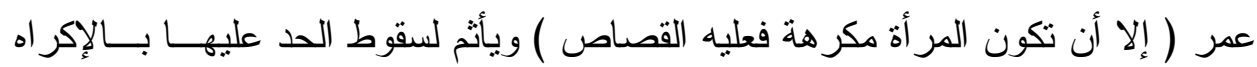

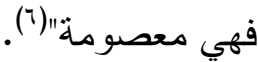

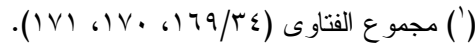

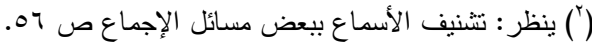

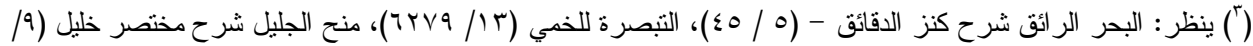

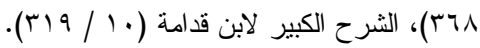

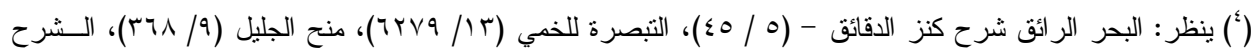

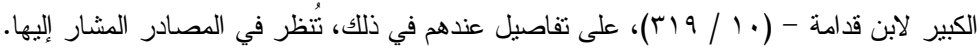

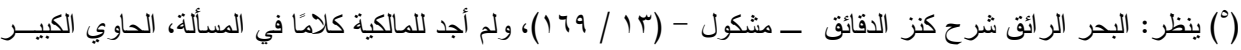

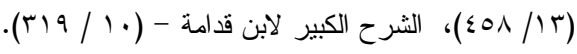

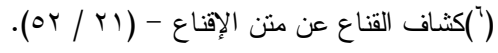


1- وروي أن سعد بن عبادة قال : يا رسول الهه ، إن وجدت مع امر أني رجلا أقتله أو أو

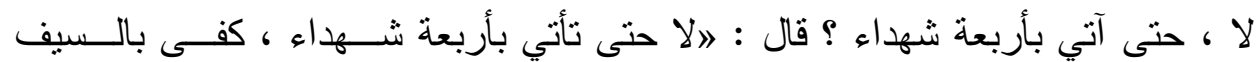
شاهداه ('). (1)

يعني شاهدا عليك ، ومعنى هذا السؤ ال أنه سأل عن سقوط القود (؟).

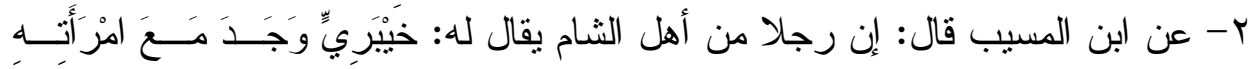

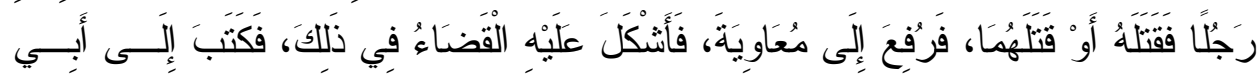

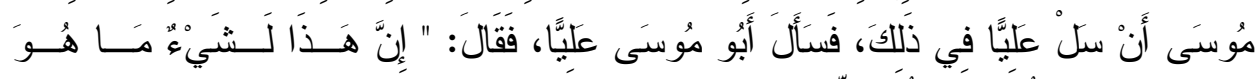

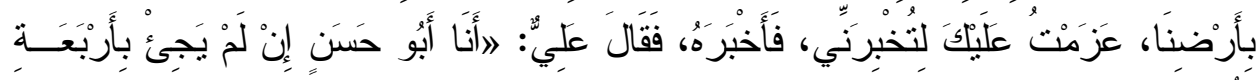

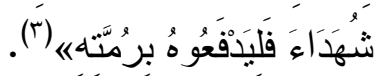

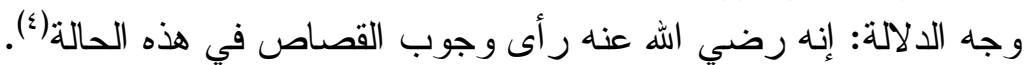

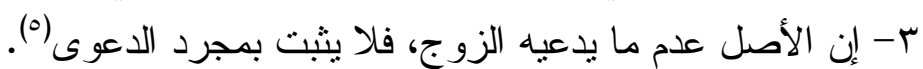
ع- إن الزوج مقر بالقتل ومدع سقوط القصاص؛ فوجب القصاص عليه(؟).

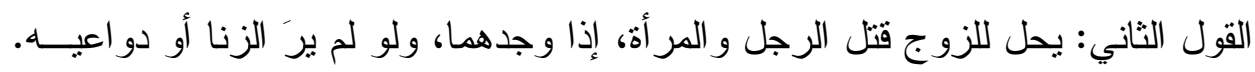
وهو قول عند الحنفية('). الأدلة:

يمكن أن يستدل لهم، ببعض الآثار عن الصحابة رضي الهه عنهم، نسوق منها ما يلي:

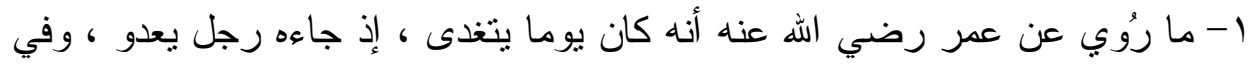

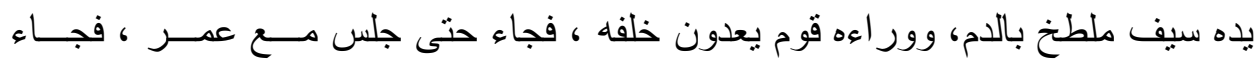

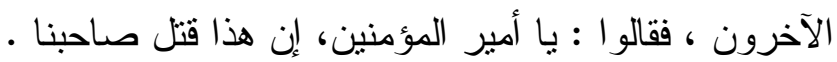

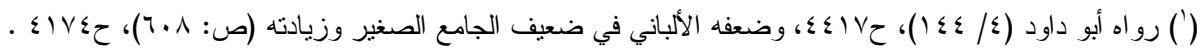

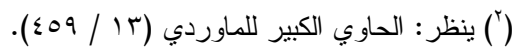

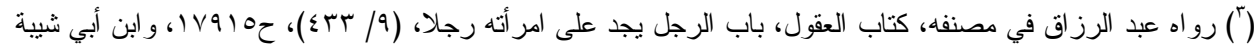

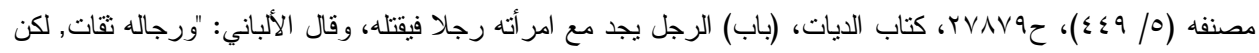

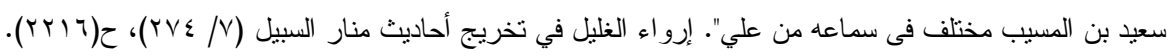

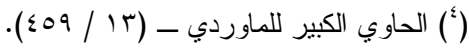

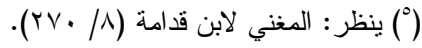

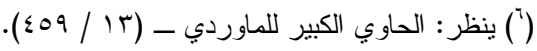

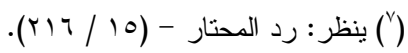


فقال له عمر : اما يقولون ؟) فقال : يا أمير المؤمنين ، إني ضربت فخذي امر أتسي ،

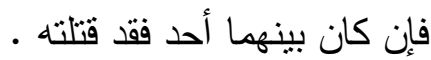
فقال عمر : ما يقول ؟ قالو ا : يا أمير المؤمنين ، إنه ضرب بالسيف ، فوقع في وســ

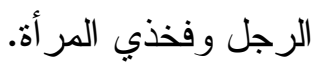
فأخذ عمر سيفه فهزه ، ثم دفعه إليه ، وقال : "إن عادوا فعده")

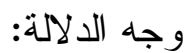

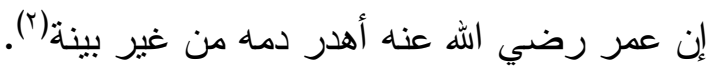

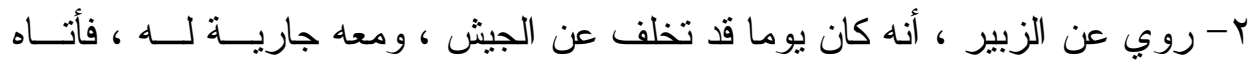

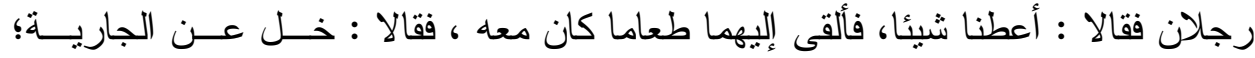

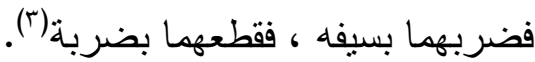

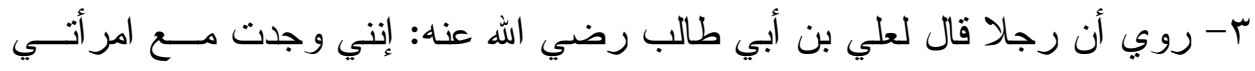

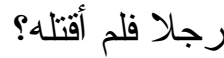

فقال علي : پأما إنه لو كان أبا عبد الله لقتلتهه. يعني الزبير بن العو ام(ئ.

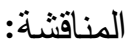

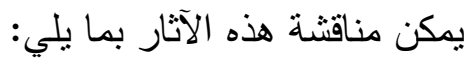
1- يمكن أن يشتهر ذلك عن الصائل، و وانتهار الحال بالاستفاضة يغتـي عـن البينـــة الخاصة (०).

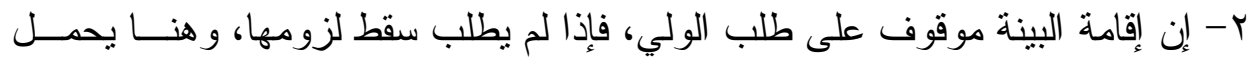

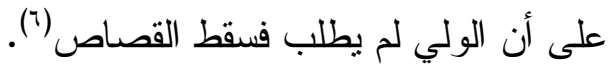
r- يحتمل أن الولي قد اعترف بذللك، وحينها يسقط القصاص(")

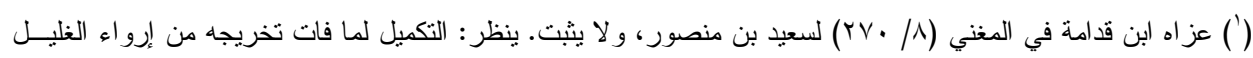

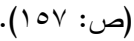

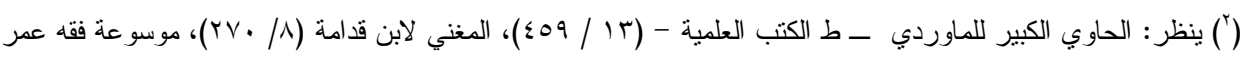

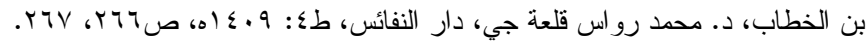

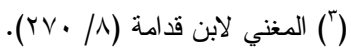

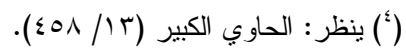

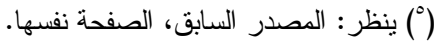

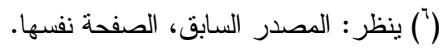

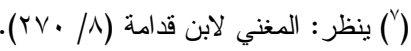




\section{الموازنة بين رأي شيخ الإسلام وأقوال الفقهاء:}

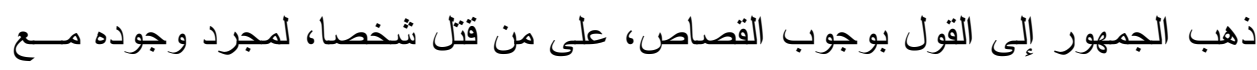

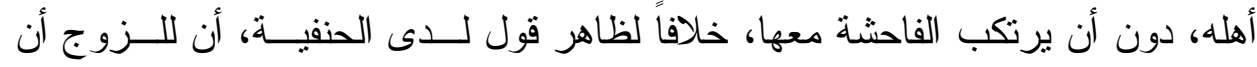
يقتلهما بمجرد خلوتهما. وقد رأى الثيخ أن الأحوط هو الأخذ بقول الجمهور ، وأن على الجاني التوبة من هــذا

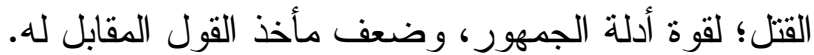

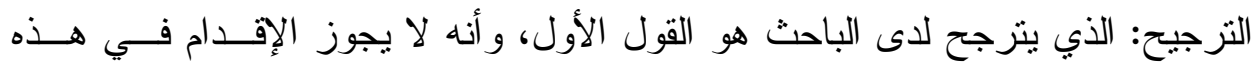

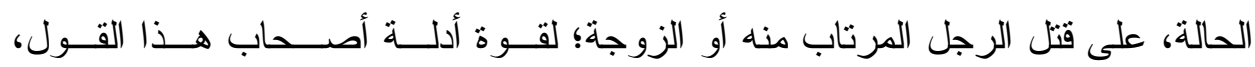
وسلامتها من المعارض الرضا فاجح.

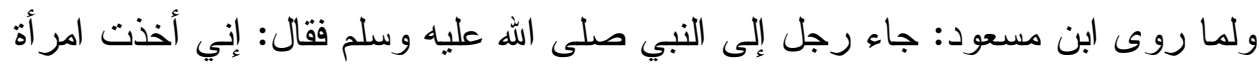

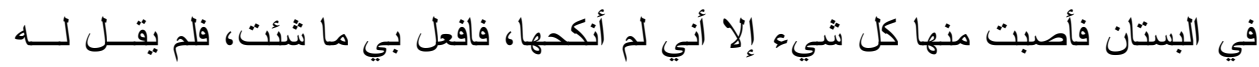

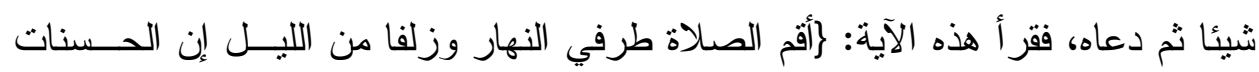

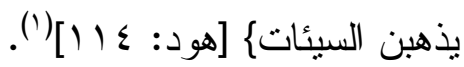

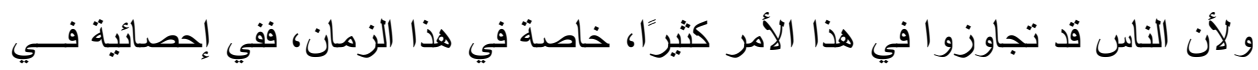

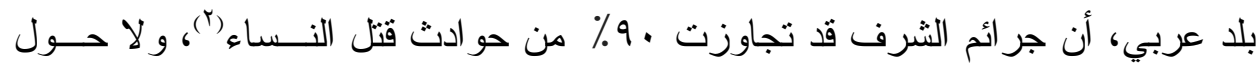

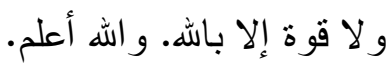
الفرع الثاني: الأخذ بالأحوط في كفارة القتل الفاله العمد:

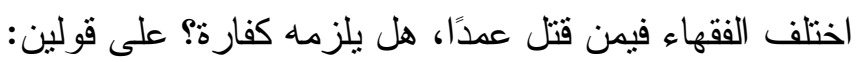

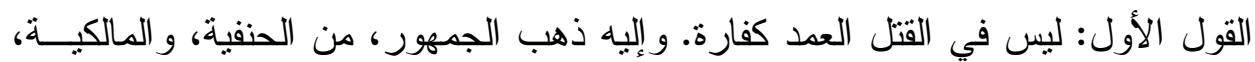
و الحنابلة، و اختاره ابن باز و العثيمين (r).

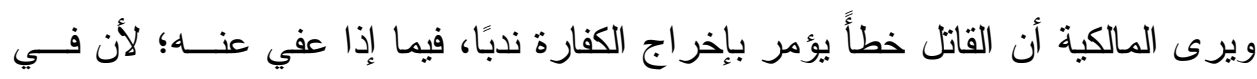

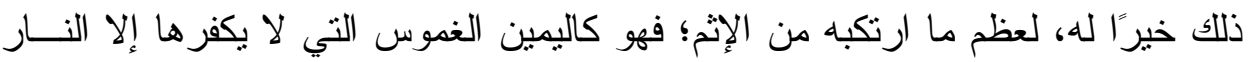

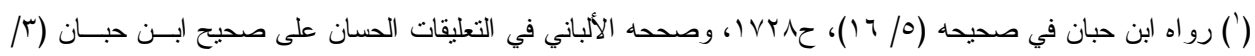
IVroz، (rT)

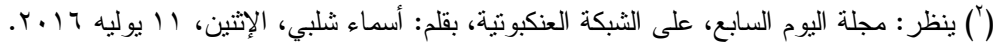

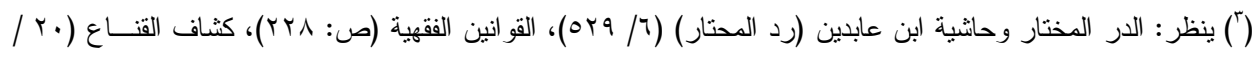

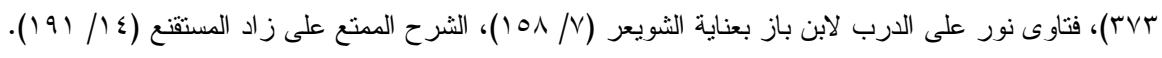


أو عفو الباري، فالمطلوب منه المبادرة إلى التوبة و التقرب إلى الله بالكفارة، وبكل مـاس ألـاء

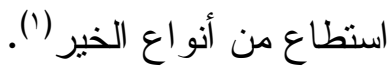
الأدلة:

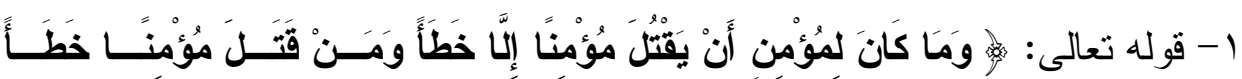

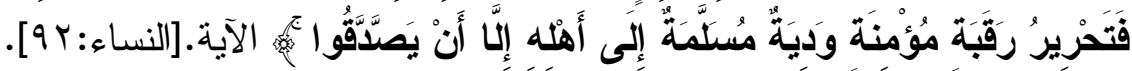

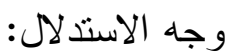

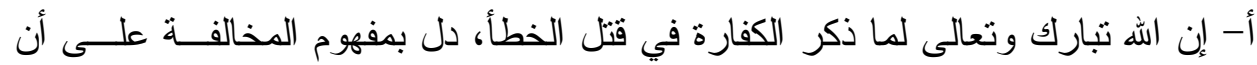

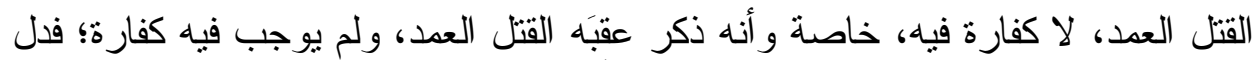

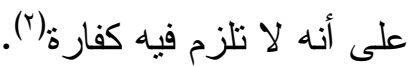

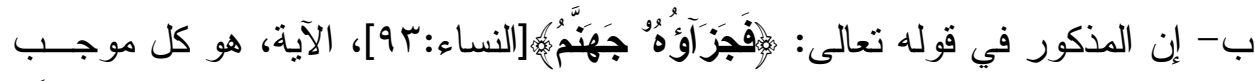

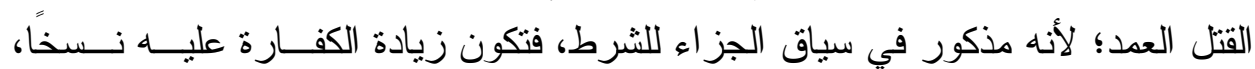
وهو لا يجوز بالر أي (r). ץ- ما روي أن الحارث بن سويد رضي الله عنه قنل رجلا ، الأفأوجب النبي صلى الله عليه وسلم عليه القود ولم يوجب كفارة) (ء). ץ- حديث عمرو بن أمية الضمري قتل رجلين في عهد النبي - صلى الله عليه وســلم

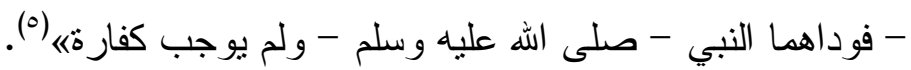
وجه الدلالة من الحديثين الثريفين: إنه عليه الصلاة والسلام أوجب القصاص في القتل العدد، ولم يوجب كفارة، فدل علــى أنها غير واجبة في القتل العدد(؟).

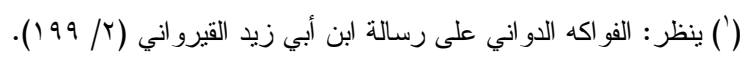

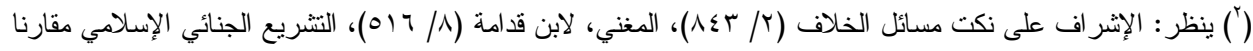

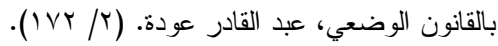

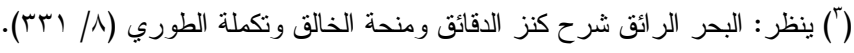

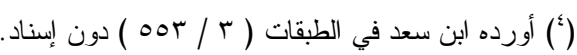

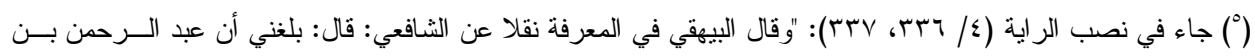

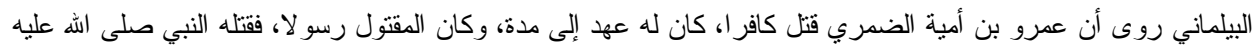

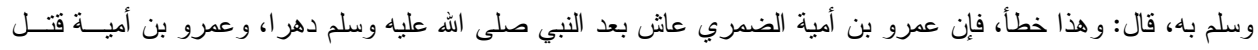

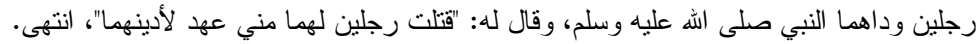

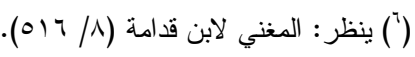


ع- إن القتل العدد جناية لا تشرع فيها الكفارة؛ لأنها أعظم من أن تكفر ؛ كما في اليمين

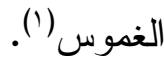
هـ إن العمد معنى موجب للقتل، فلم يجب على فاعله كفارة؛ قياسًا علـــى الزنـــا مـــع

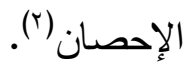
7- إن الكفارة دائرة بين العبادة و العقوبة، فلا بد أن يكون سببها كذللك دائر ا بين الحظر

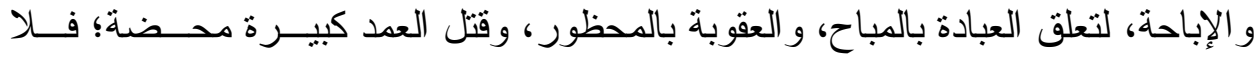

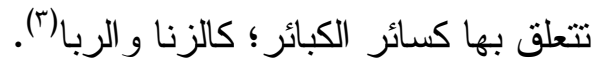

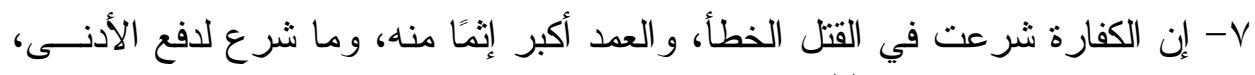
فإنه لا يدل على دفع الأعلى (๕).

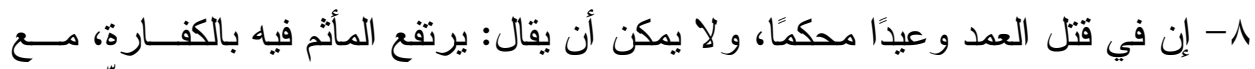

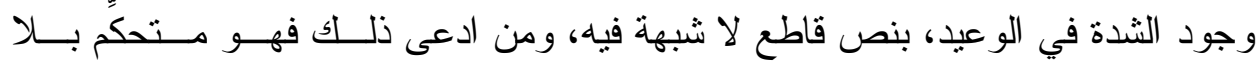
دليل (0).

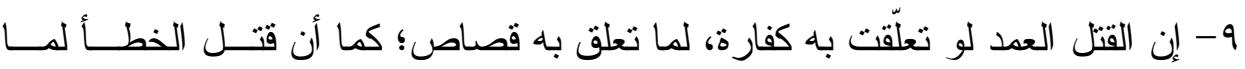

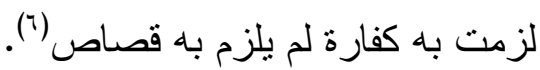

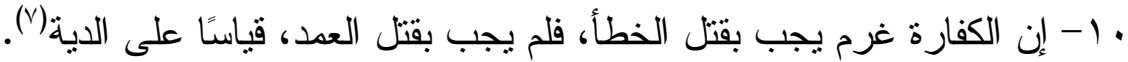

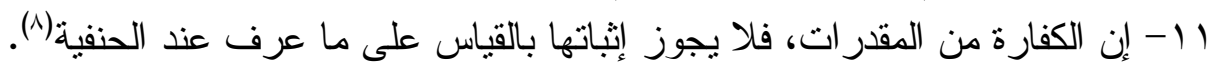
مناقتشة:

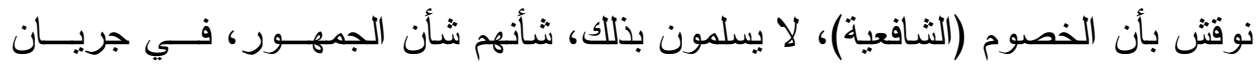

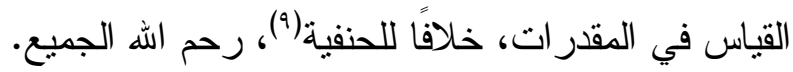

(') ينظر : حاثشية الصاوي على الثرح الصغير = بلغة السالك لأقرب المسالك (ع/ 0. ــ).

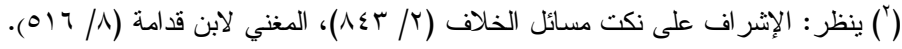

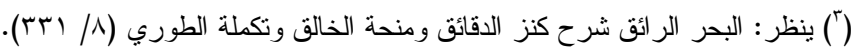
(") ينظر : المصدر السابق، الصفحة نفسها. (") (1) ينظر : المصدر السابق، الصفحة نفسها.

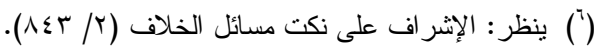
(') ينظر : المصدر السابق، الصفحة نفسها.

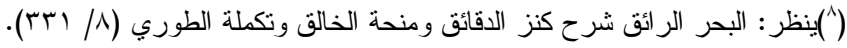

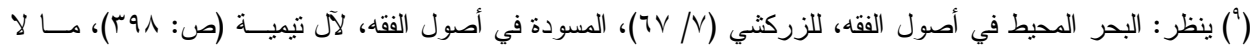

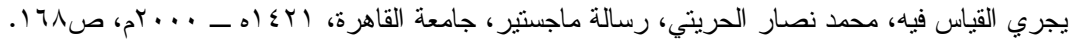


القول الثاني: يلزم القاتل عمدًا كفارة. و إليه ذهب الثافعية، وهو رواية عند الحنابلة('). الأدلة:

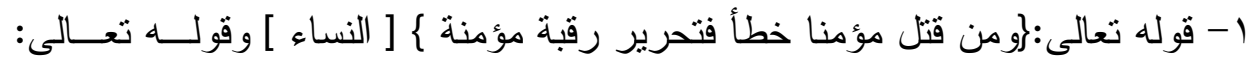

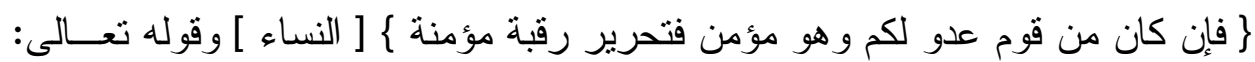

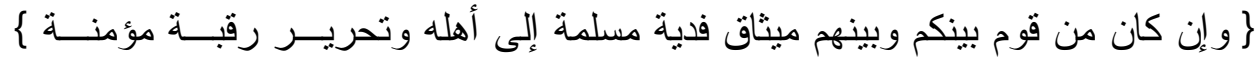
] [ النساء وجه الدلالة:

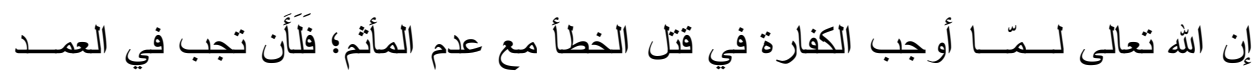

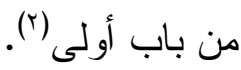

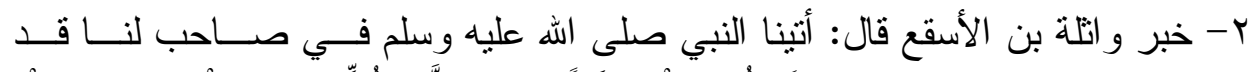

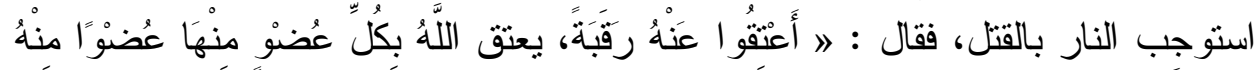

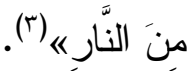

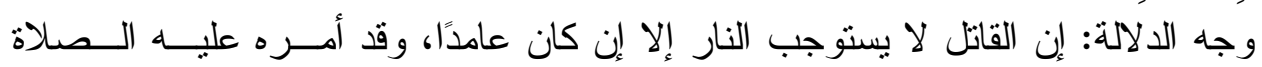

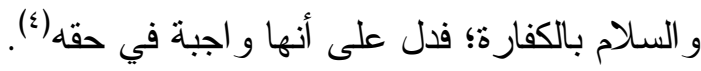
المناقثة:

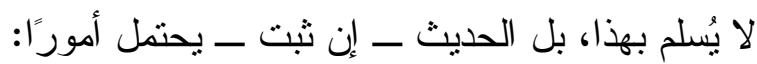

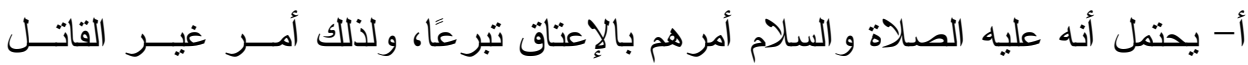

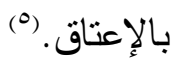

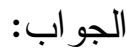
أجيب عنه بأن: الخطاب وإن نوجه إلى السائل، فالمر اد به القاتل؛ لأنه أوجب الكفــارة

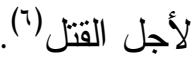

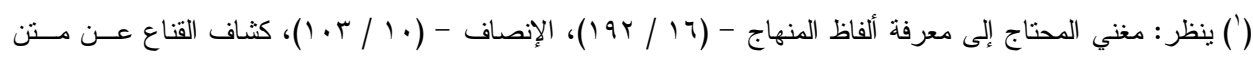

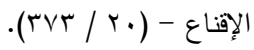

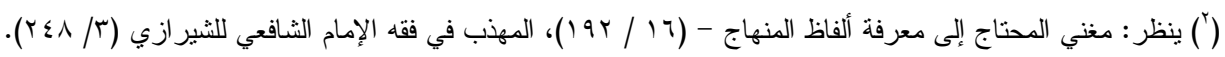

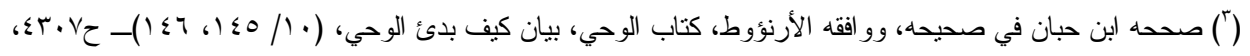

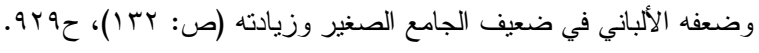

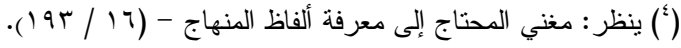

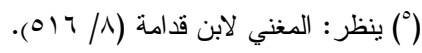

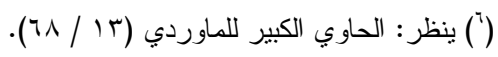


ب- يحتمل أن القتل كان خطأُ، وسماه موجبًا، بمعنى أن فوّت النفس بالقتل (').

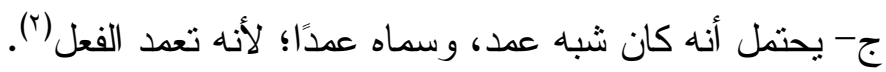
ب- روي عن عمر بن الخطاب أنه قال : يا رسول الله ، إني وأدت في الجاهلية، فقــال

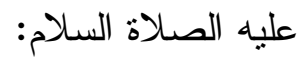
(أعتق عن كل موؤودة رقبة) (ז).

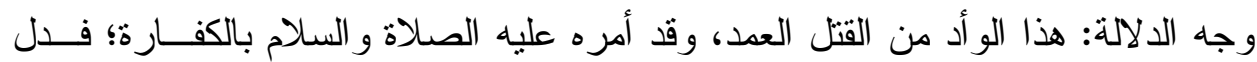

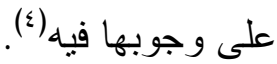

ع - إنه قتل آدميًا مضدونًا ، فوجبه أب أن تُستحق فيه الكفارة؛ قياسًا على القتل الخطأ(ه).

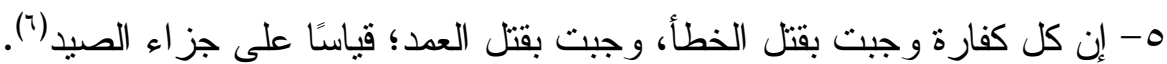
المناقثة: لا يسلم بذلك؛ لعدم الممانتلة بين قتل الصيد عمدًا، وقتل النفس عمدًا، فالكفارة في الــنفس

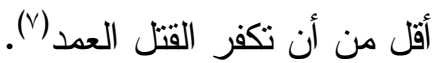

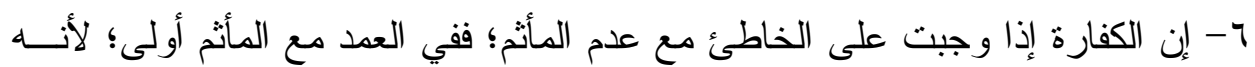

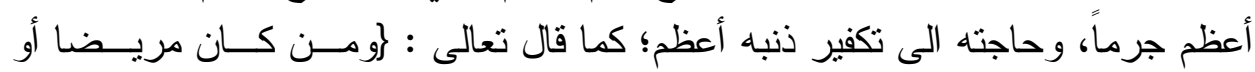

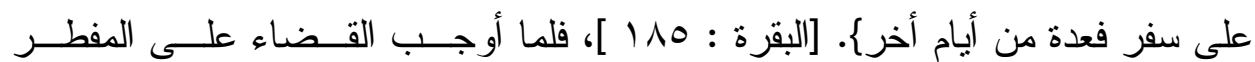

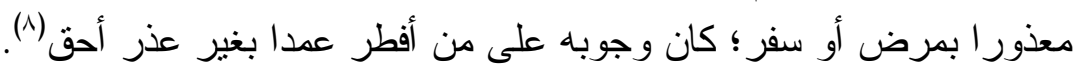

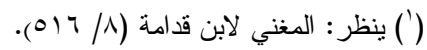

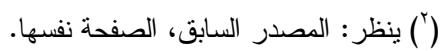

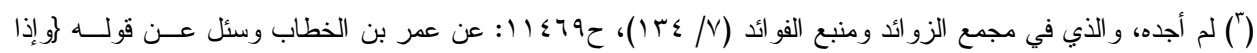

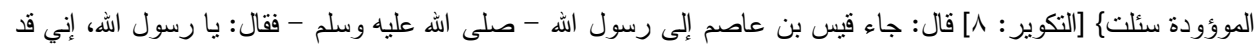

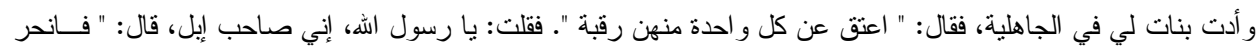

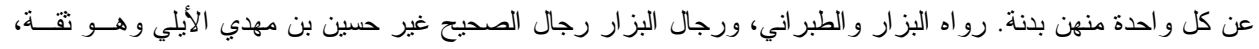

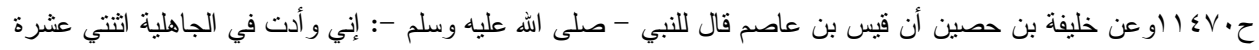

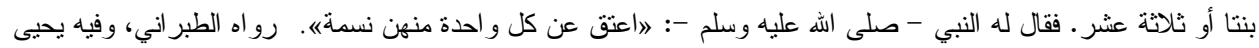

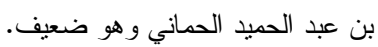

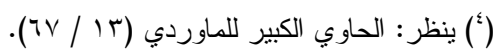
( ) (1) ينظر : المصدر السابق، الصفحة نفسها.

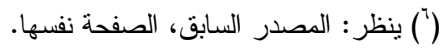

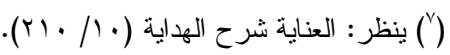

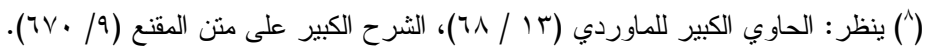


المناقثة:

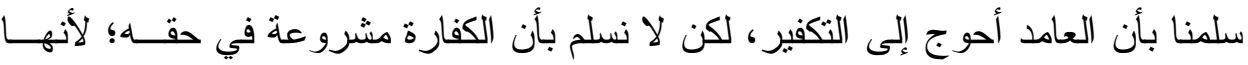
وجبت في القتل الخطأ، لتمحو إثمه؛ لكونه لا يخلو من تفريط، فلا يلزم من ذلك إيجابها في موضع عظُ الإثم فيه، بحيث لا يمكنها رفعها' (').

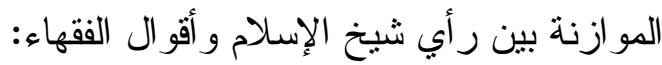

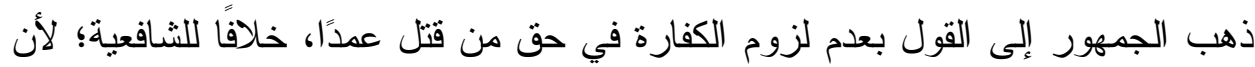
جرمه أكبر من أن تمحوه الكفارة.

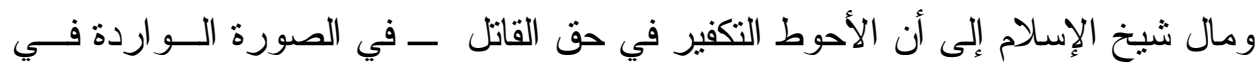

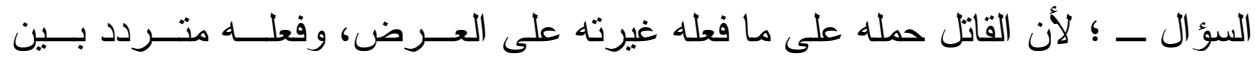

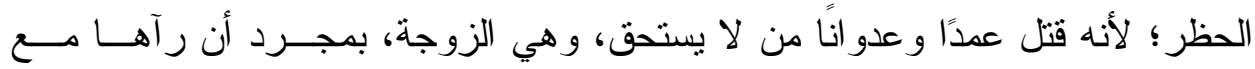

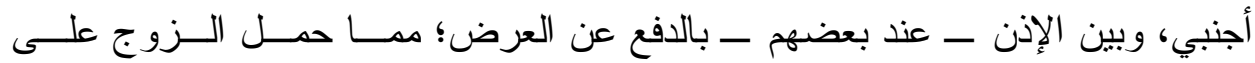

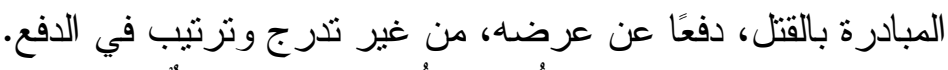

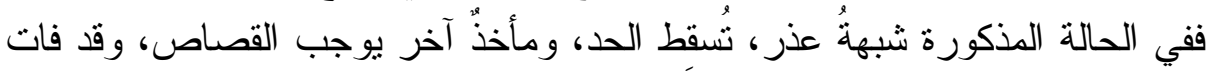

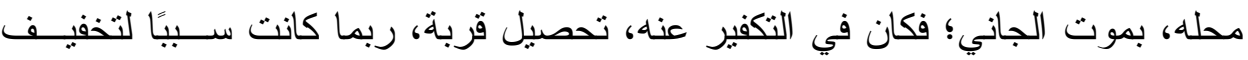

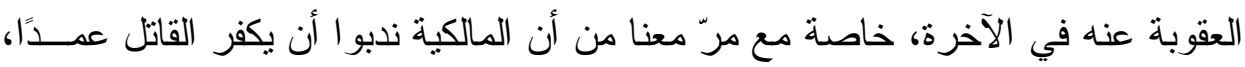

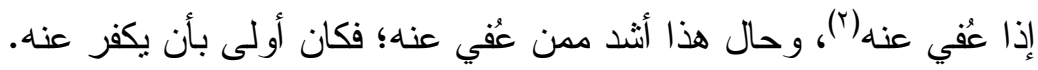

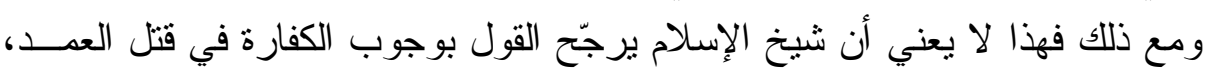

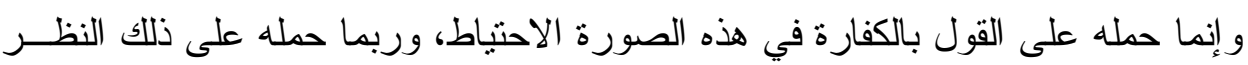

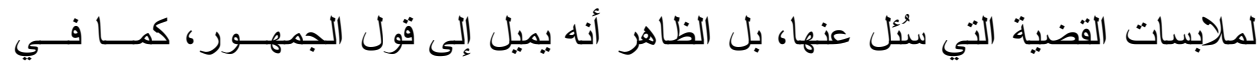

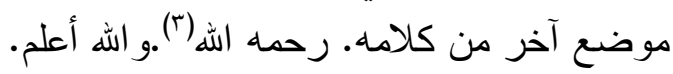

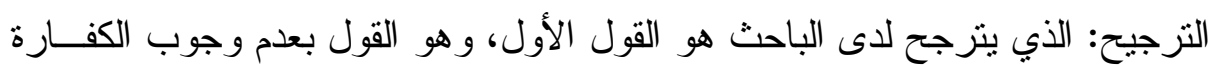

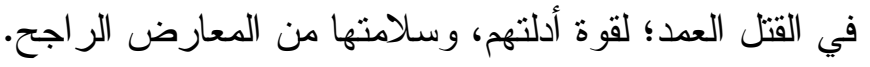

\author{
(') ينظر : المغني لابن قدامة (N/ (1) (0).

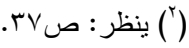

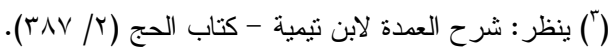




\section{الخاتمة}

و ها نحن بفضل اله تعالى نبلغ في هذا البحث الخاتمة، نسأل الله حسنها، وأذكـــر فيهـــا أهم النتائج التي توصلت إليها، و أهم التوصيات:

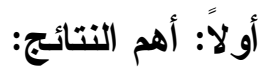

1- يعفى عن بسير بول الفأر ؛ لأنه مما تعم به البلوى.

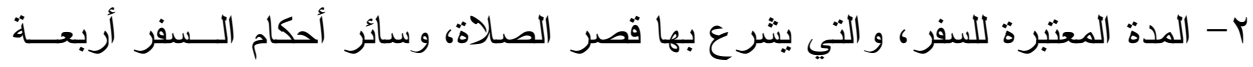
أيام فأقل، وما ز اد على ذللك فهو إقامة.

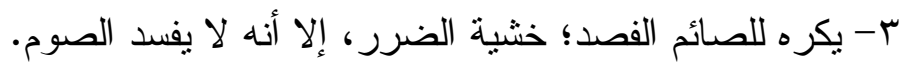

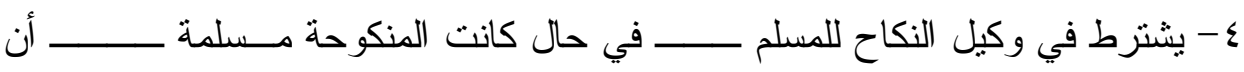
يكون مسلمًا.

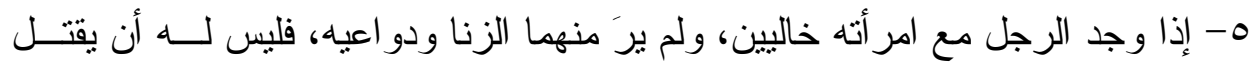

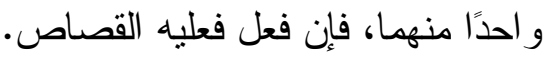

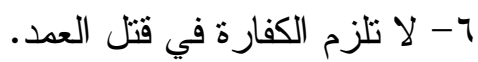
V ليس من فقه العالم كثرة الاحتياط في المسائل، بل ينبغي له البحث و التحرير ؛ ليفتي

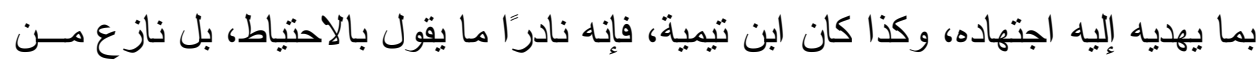
قال به في عدد من المسائل.

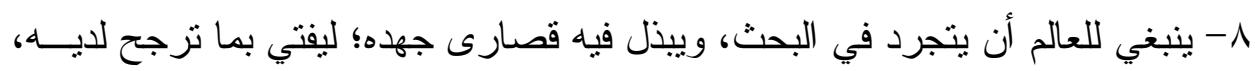

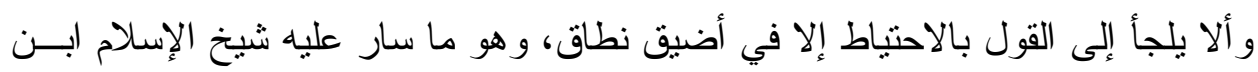
تيمية رحمه الهه تقعيدًا وتطبيقًا.

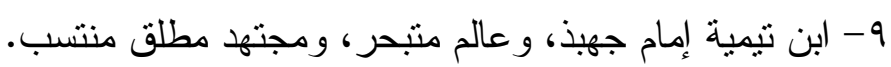

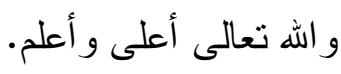

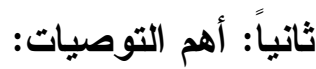
1- إنشاء مر اكز تُعنى بفقه هذا الإمام، و أمثاله من أئُة الإسلام المجتهدين. r- مو اصلة البحوث في الجو انب المختلفة، من فقه هذا الإمام، فقهًا، وتأصيلًا، وتقعيدًا. وباله التوفيق، وصلى الله وسلم على سيدنا ونبينا محمد، و آله وصحبه أجمعين. 


\section{قائمة المصادر والمراجع}

القرآن الكريم .

- - أحكام القرآن، ابن الفرس، تحقيق: د. طه بو سريح، وآخرين، دار ابن حــزم، بيـروت، طـا: $.1 \leqslant Y V$

أحكام صلاة المسافر، در اسة فقهية مقارنة، د. وضحة عليوي الجبوري، كلية العلوم الإسلامية،

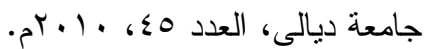
الآثار، الإمام محمد بن الحسن الثيباني، المحقق: أبو الوفا الأفغاني، دار الكتب العلمية، بيروت، بدون طبعة، بدون تاريخ. الاحتياط، الحكيم التزمذي، بعناية عبد الو احد جهداني، دار الكتب العلمية، لنبان، Iل إبم.

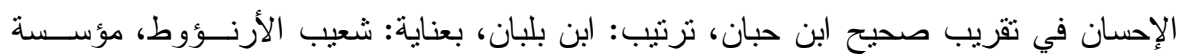

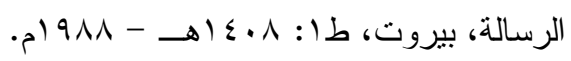

الإحكام في أصول الأحكام، علي ابن حزم، المحقق: أحمد محمد شاكر، دار الآفــاق الجديــدة، بيروت، بدون طبعة، وبدون ناريخ.

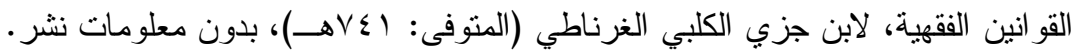

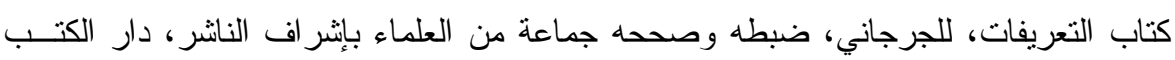

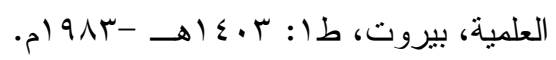

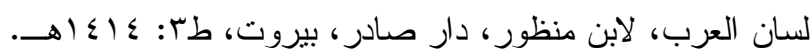

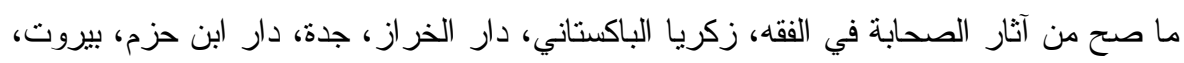
ط نصب الر اية لأحاديث الهداية، مع حاثثيته بغية الألمعي في تخريج الزيلعي، للزيلعي، تحقيـق:

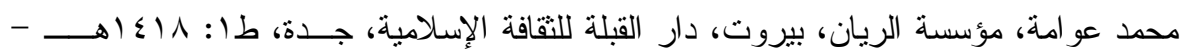
. $) 99 \mathrm{~V}$

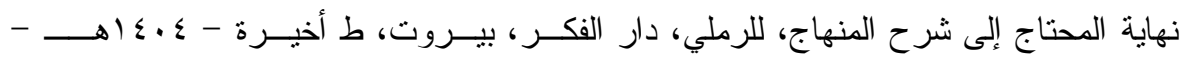
. م) $9 \wedge \varepsilon$ إرو اء الغليل في تخريج أحاديث منار السبيل، محمد ناصــر الــدين الألبـاني، بيـروت، طب: $\rightarrow 1 \leqslant .0$ - - أساس البلاغة، أبو القاسم محمود بن عمرو بن أحمد، الزمخشري، تحقيق: محمد عيون السود، دار الكتب العلمية، بيروت، بدون طبعة، وبدون تاريخ. - الاستذكار ، ابن عبد البر، تحقيق: سالم محمد عطا، محمد علي معوض، دار الكتب العلميــة -

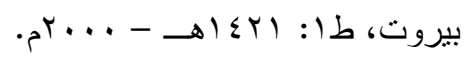


- - أسنى المطالب في شرح روض الطالب، زكريا الأنصاري، دار الكتاب الإسلامي، بدون طبعة، وبدون تاريخ.

الإثر اف على نكت مسائل الخلاف، القاضي عبد الوهاب، المحقق: الحبيب بن طاهر، دار ابن

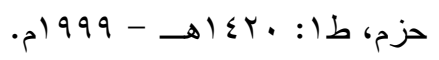

الإقناع في مسائل الإجماع، ابن القطان، تحقيق: حسن فوزي الصعيدي، الفاروق الحديثة للطباعة

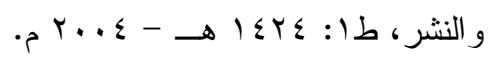

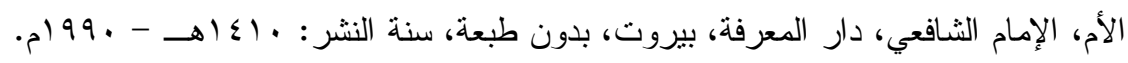

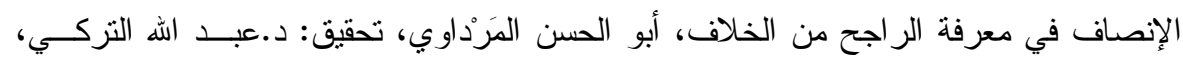

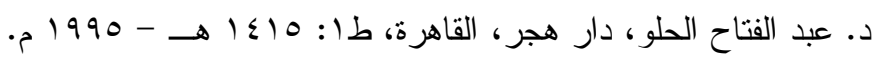

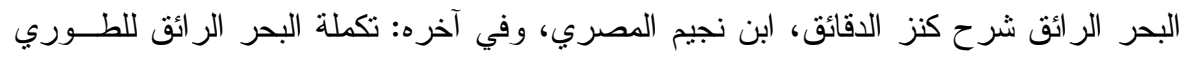

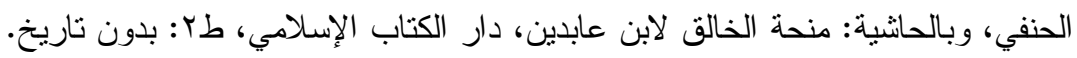

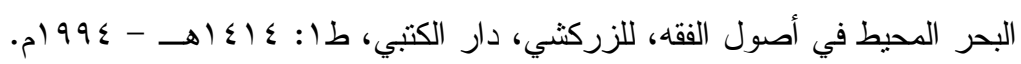

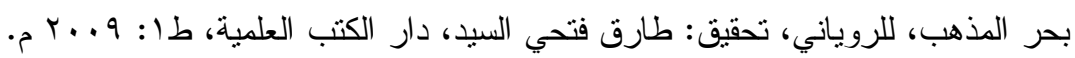

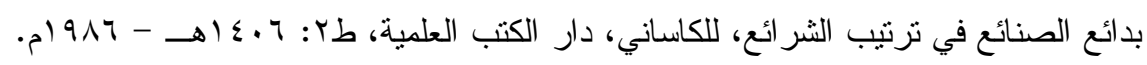

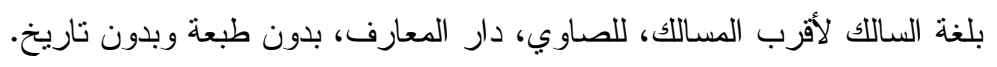

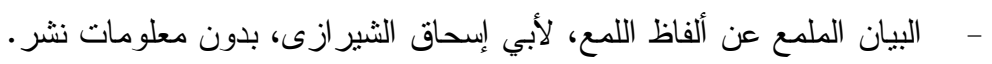

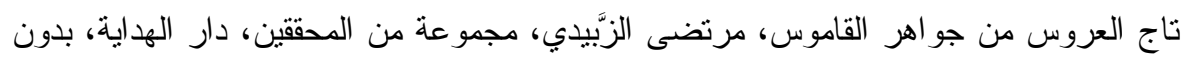
طبعة، وبدون تاريخ.

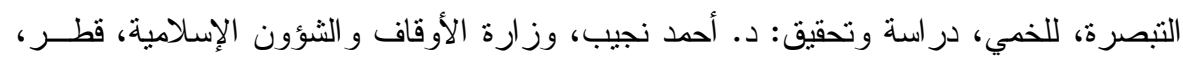
طا:

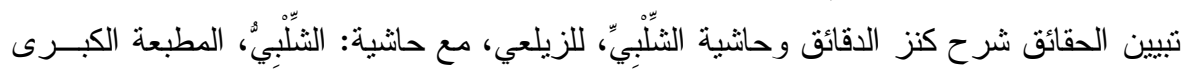

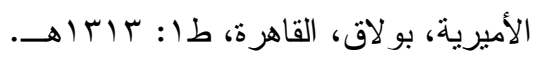

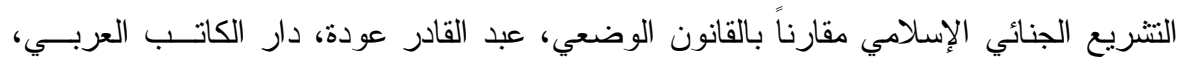
بيروت، بدون طبعة، وبدون تاريخ.

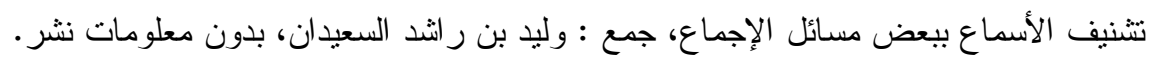

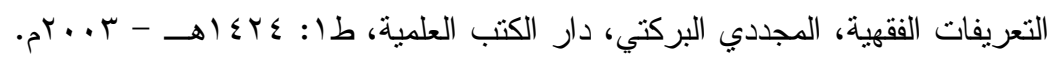

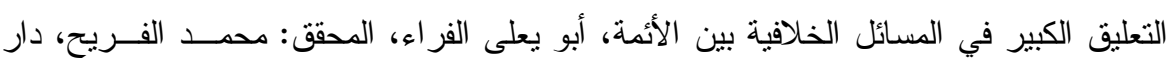

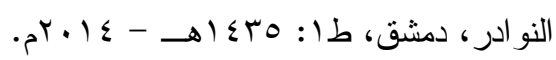

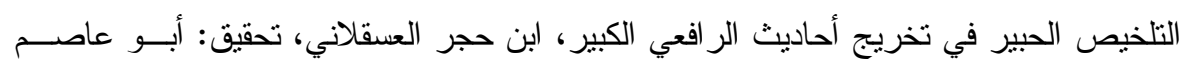

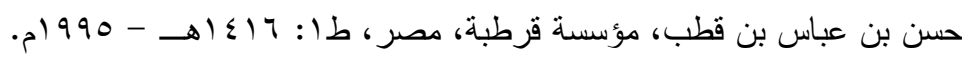




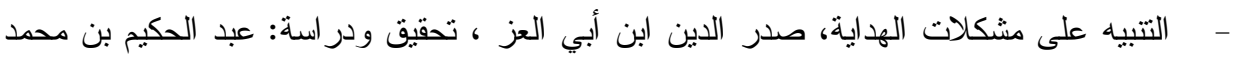

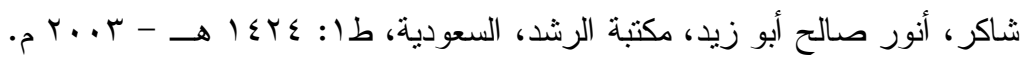

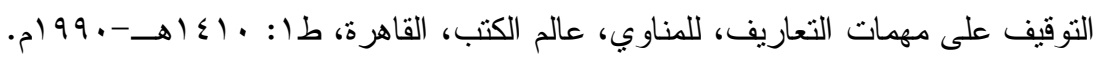

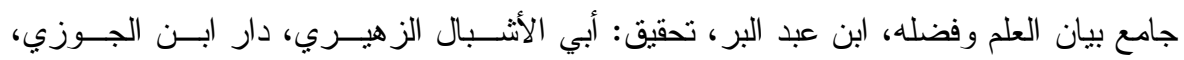

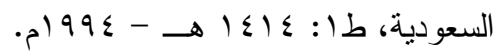

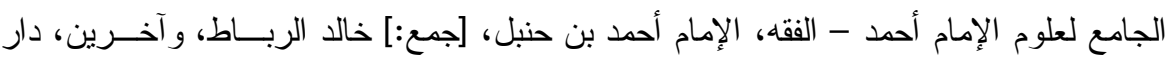

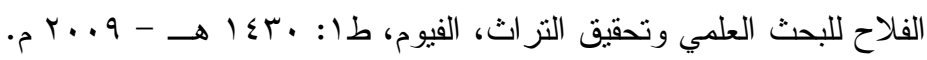

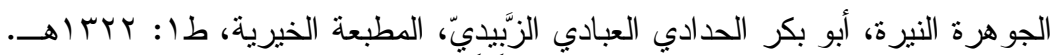

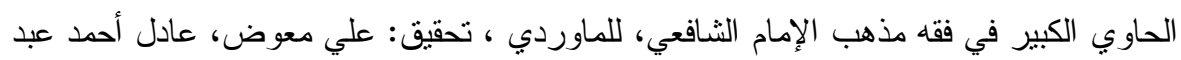

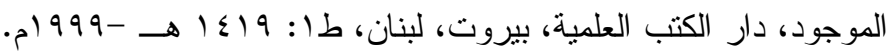

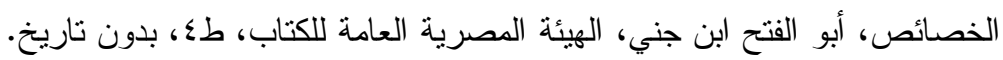

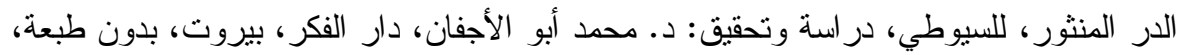
وبدون تاريخ.

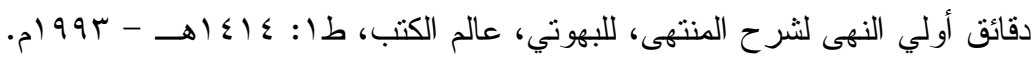

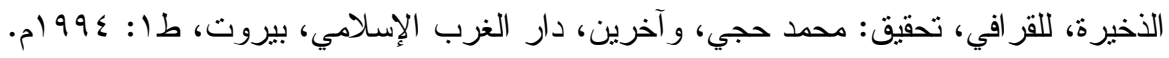

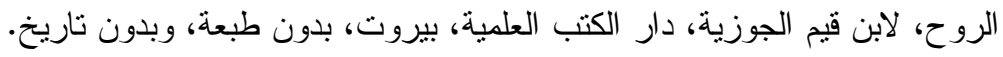

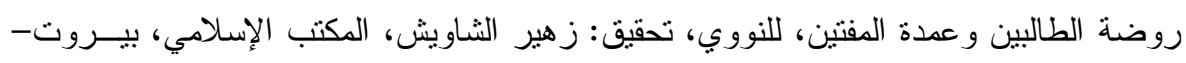

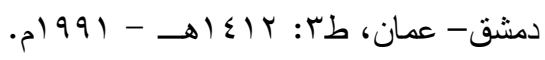

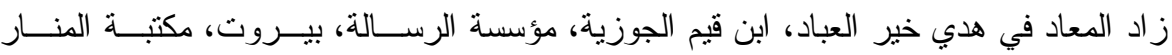

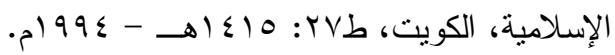
سنن أبي داود، سليمان بن الأشعث، تحقيق: محمد محيي الدين عبد الحميد، المكتبة العـصرية، صيدا، بيروت.

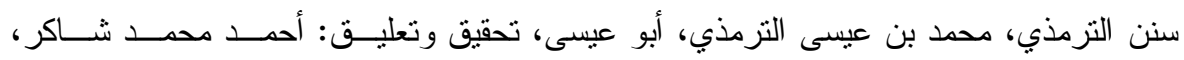

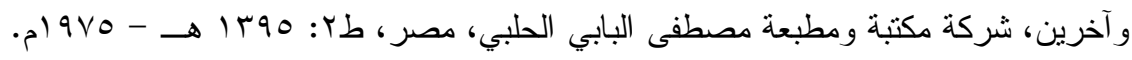

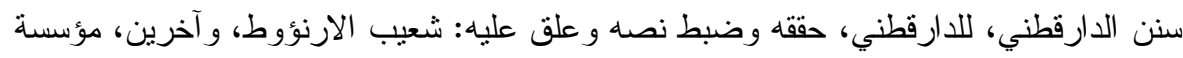

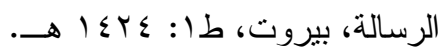
السنن الكبرى وفي ذيله الجوهر النقي، للبيهقي، مؤلف الجوهر النقي: ابن التركماني، مجلـس النس

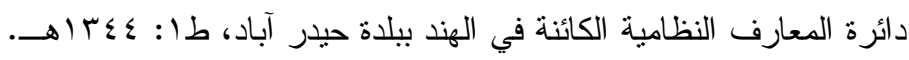

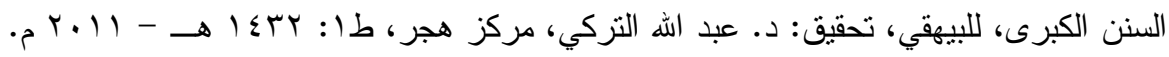

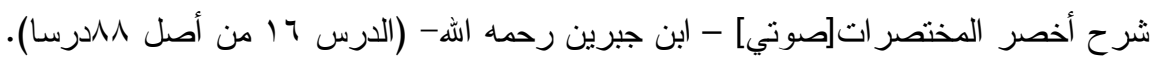




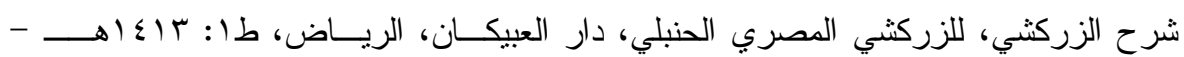

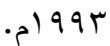

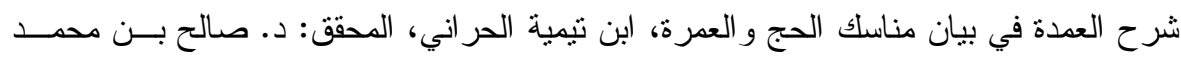

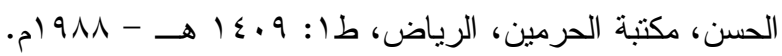

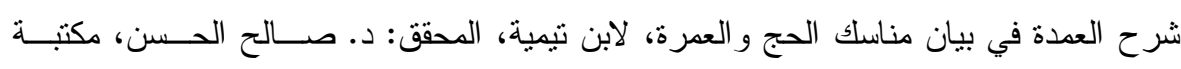

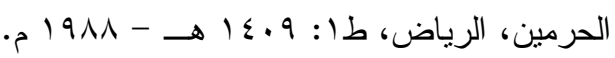

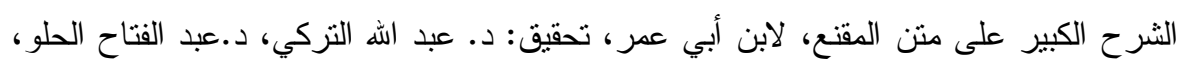

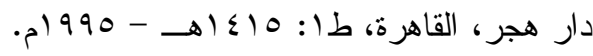

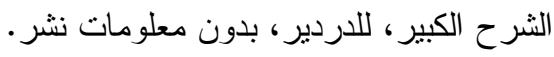

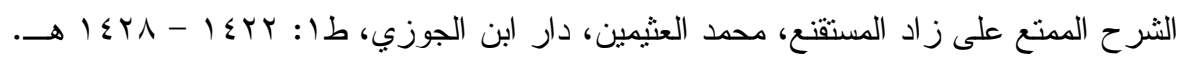

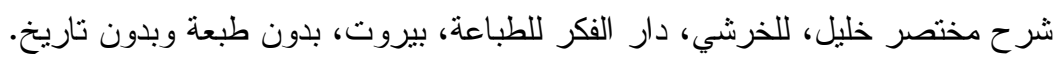

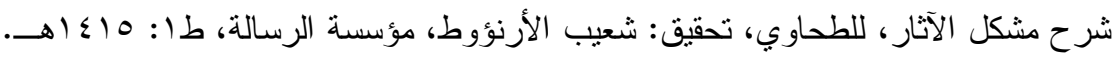

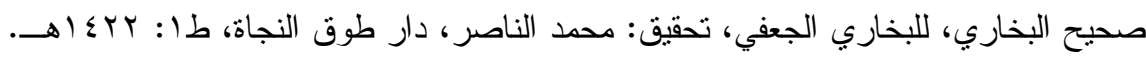

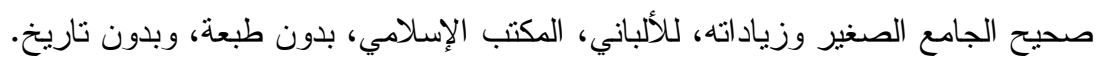

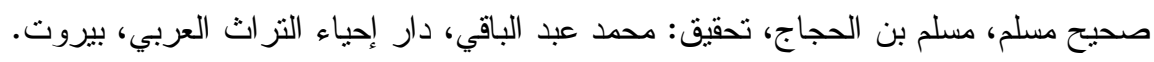

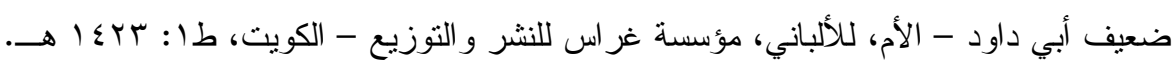

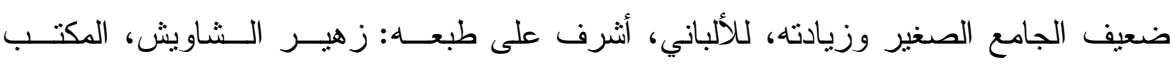

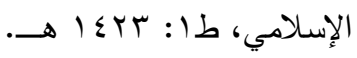

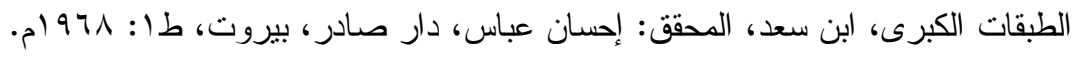

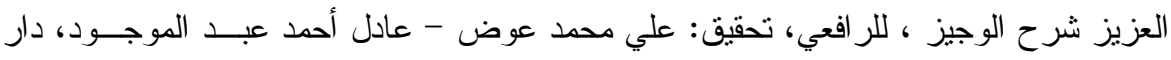

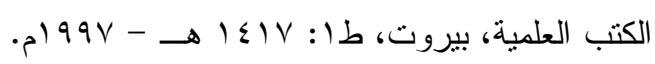

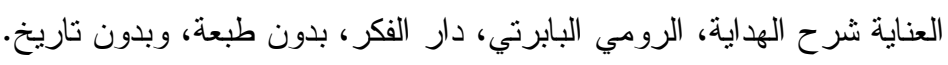

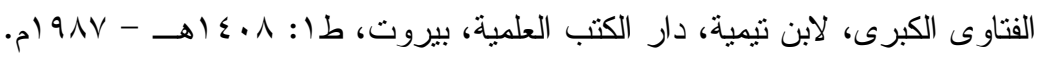

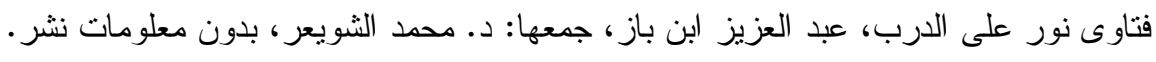

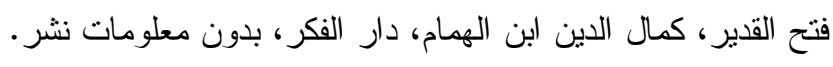

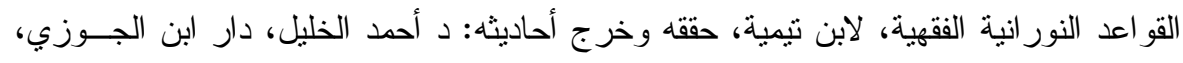

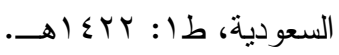

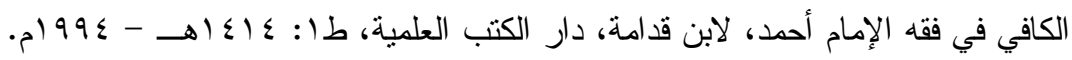

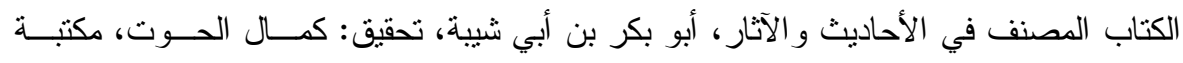

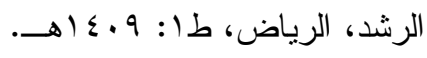


كثاف القناع عن متن الإقناع، للبهوتي، دار الكتب العلمية، بدون طبعة، وبدون تاريخ.

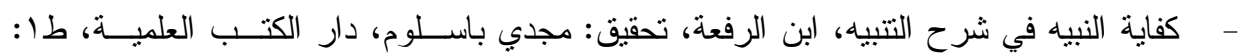
. الكليات، للكفوي، الدحقق: عدنان درويش - محمد المصري، مؤسسة الرسالة، بيروت، بـدون طبعة وبدون تاريخ.

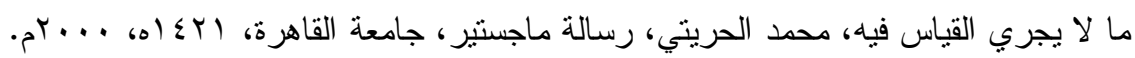

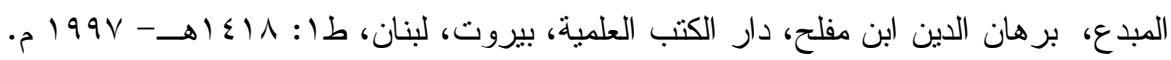

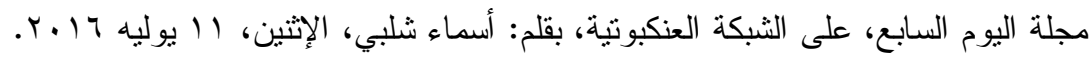

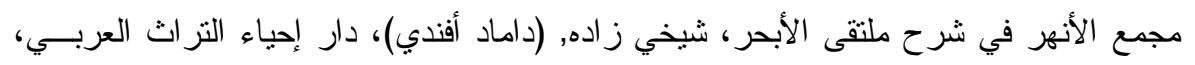
بدون طبعة وبدون تاريخ. مجمع الزوائد ومنبع الفو ائد، للهيثمي، الدحقق: حسام الدين القسي، مكتبة القسي، القاهرة، ط: .م) $99 \leq$ ، $1 \leq 1 \leq$

المجموع ((مع تكملة السبكي و المطيعي))، للنووي، دار الفكر ، بدون طبعة، وبدون تاريخ.

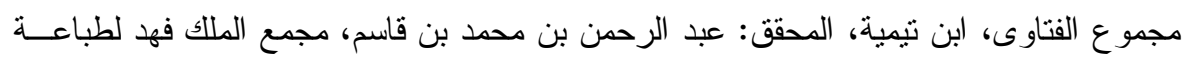

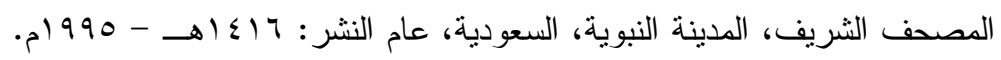

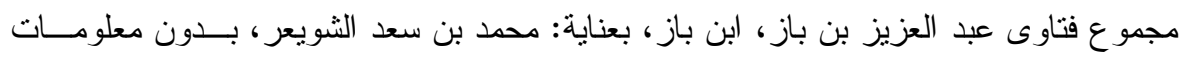
نشر مجموعة الرسائل و المسائل، ابن تيمية، علق عليه : السيد محمد رشيد رضـــا، لجنـــة التـــراث العربي، بدون معلومات نشر.

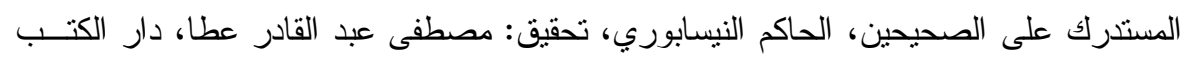

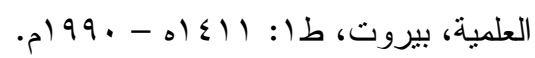

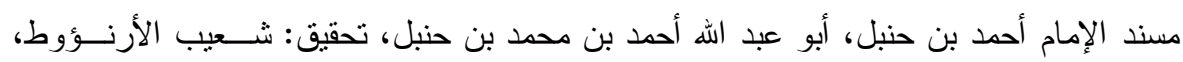

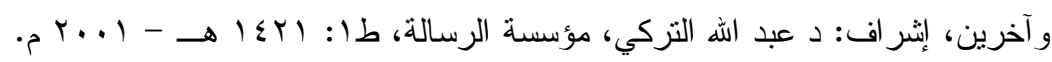

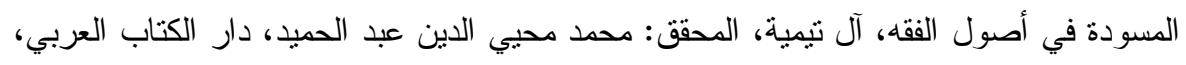
بدون طبعة، وبدون تاريخ. المصباح المنير في غريب الثرح الكبير، للفيومي، المكتبة العلمية، بيروت، بدون طبعة، وبدون تاريخ.

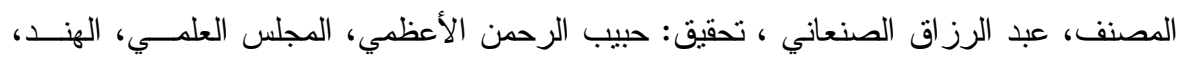

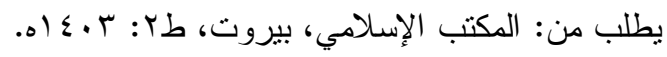

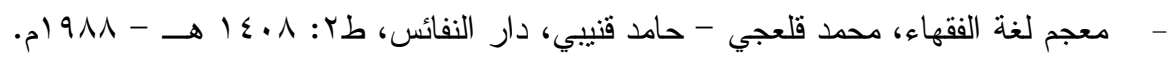




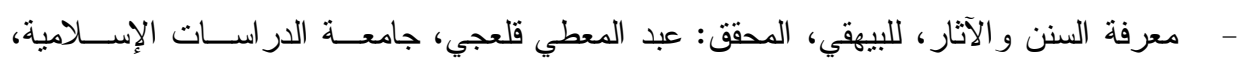

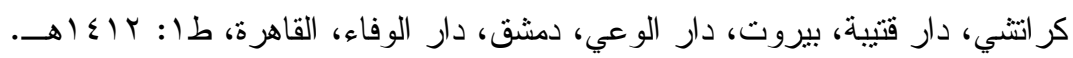

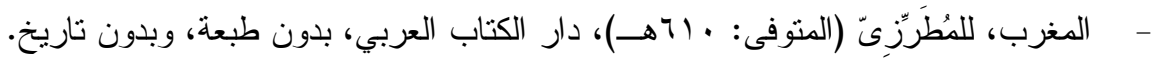

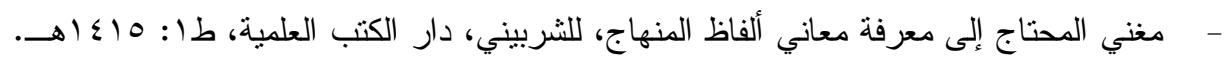

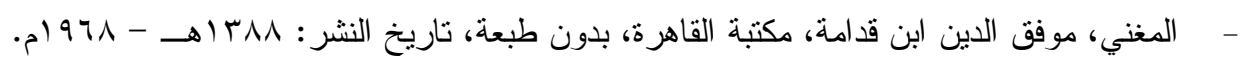

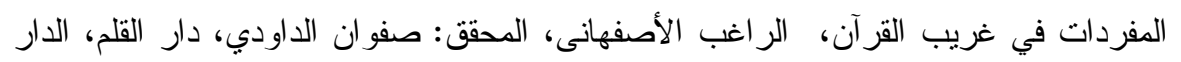

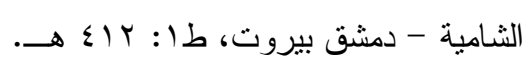
- - منار السبيل في شرح الدليل، ابن ضويان، المحقق: زهير الثشاويش، الدكتب الإســلامي، طع: . $9199-1 \varepsilon .9$ - - منح الجليل شرح مختصر خليل، عليش، دار الفكر، بيروت، بــدون طبعـة، تــاريخ النـشر : . 9

- - المهذب، للثير ازي، دار الكتب العلمية، بيروت، بدون طبعة، بدون سنة النشر .

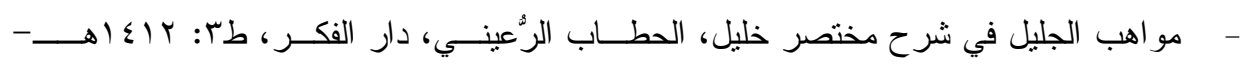
. - موسوعة فقه عمر بن الخطاب، د. محمد رواس قلعة جي، دار النفائس، ط؛: 9 ــ اه. و الحمد لله الذي بنعمته تتم الصالحات،، ب، 